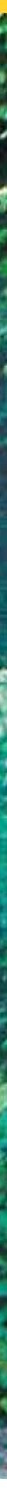

\title{
Preventing the risk of corruption in REDD+ in Indonesia
}

Ahmad Dermawan

Elena Petkova

Anna Sinaga

Mumu Muhajir

Yayan Indriatmoko

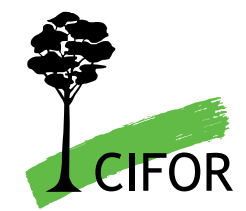



Working Paper 80

\section{Preventing the risk of corruption in REDD+ in Indonesia}

Ahmad Dermawan

Elena Petkova

Anna Sinaga

Mumu Muhajir

Yayan Indriatmoko 
Working Paper 80

(C) 2011 Center for International Forestry Research All rights reserved

Dermawan, A., Petkova, E., Sinaga, A., Mumu Muhajir, M. and Indriatmoko, Y. 2011 Preventing the risk of corruption in REDD+ in Indonesia. United Nations Office on Drugs and Crime and Center for International Forestry Research, Jakarta and Bogor, Indonesia.

Cover photo by Daniel Murdiyarso

\section{CIFOR}

Jl. CIFOR, Situ Gede

Bogor Barat 16115

Indonesia

$\mathrm{T}+62(251) 8622-622$

$\mathrm{F}+62(251) 8622-100$

E cifor@cgiar.org

\section{www.cifor.org}

Any views expressed in this publication are those of the authors. They do not necessarily represent the views of CIFOR, the authors' institutions or the financial sponsors of this publication. 


\section{Contents}

Abbreviations $\quad$ v

Acknowledgements

1 Introduction 1

2 REDD+ in Indonesia 3

3 REDD+, corruption and anti-corruption efforts in Indonesia $\quad 6$

3.1 The potential for corruption in REDD+ 6

$\begin{array}{ll}3.2 \text { The forestry sector and anti-corruption efforts } & 7\end{array}$

4 REDD+ policymaking $\quad 12$

4.1 Framework strategies and long-term reforms $\quad 12$

4.2 Forest land use 13

4.3 Rights and tenure $\quad 15$

$\begin{array}{ll}4.4 \text { Limiting forest conversion: The moratorium } & 17\end{array}$

4.5 Risk of corruption in REDD+ policymaking $\quad 18$

5 Improving coordination $\quad 21$

$\begin{array}{ll}5.1 \text { Coordinating agencies and efforts } & 21\end{array}$

5.2 Risks for REDD+ related to coordination 22

6 Climate finance $\quad 23$

6.1 Climate finance in Indonesia 23

6.2 Experience with management and distribution of forest funds in Indonesia 24

6.3 The role of banks in the Reforestation Fund 26

6.4 Learning from finance in forestry, climate and the environment 27

6.5 Risks related to REDD+ finance 28

$7 \quad$ REDD+ benefit sharing $\quad 29$

7.1 Distribution of REDD+ revenue and benefits 29

7.2 Lessons and risks for benefit sharing in REDD+ 32

8 The REDD+ project implementation framework $\quad 34$

8.1 Forest concessions and licensing $\quad 34$

8.2 Risk of corruption in REDD+ licensing

9 Forest revenues and reconciliation of accounts $\quad 38$

9.1 Report reconciliation across scales $\quad 38$

9.2 Risks of corruption in REDD+ accounting 39

10 Conclusions and recommendations 42

11 References $\quad 46$

Annexes
1

2 REDD+ pilot project in West Kalimantan $\quad 59$

3 The legal and institutional landscape : Implementing UNCAC in Indonesia 61

4 PPATK minimum standards for banks $\quad 70$

$\begin{array}{lll}5 & \text { List of participants in the consultation meetings } & 71\end{array}$ 


\section{List of tables, figures and boxes}

\section{Tables}

1 REDD+ readiness in Indonesia: Policy and institutional framework 4

2 Distribution of REDD+ revenues amongst actors 30

3 Forest concessions in Indonesia 34

\section{Figures}

1 Allocation and distribution of forest revenues 25

2 Flow of reports on taxes and fees 40

3 Corruption risks and outcomes in the REDD+ readiness phase 43

\section{Boxes}

1 Challenges to anti-corruption initiatives in Indonesia: The case of the KPK 9

2 Curbing corruption in the forestry sector: High-profile cases involving PEPs $\quad 10$

3 The Reforestation Fund 26 


\section{Abbreviations}

AFD

AF

APHI

APL

Bappenas

BPK

BPN

BUMN

CCPL

CDM

CER

COP

CSO

DNPI

DR

FAO

FATF

FCPF

FFI

FPIC

GCCA

GHG

GoI

HPK

ICCTF

IFCA

IGIF

$\mathrm{IHPH}$
L'Agence française de développement

French Development Agency

Amazon Fund

Asosiasi Pengusaha Hutan Indonesia

Indonesian Association of Forest Concession Holders

Areal penggunaan lain

area for other uses

Badan Perencanaan Pembangunan Nasional

National Development Planning Agency

Badan Pemeriksa Keuangan

Supreme Audit Board

Badan Pertanahan Nasional

National Land Agency

Badan Usaha Milik Negara

state-owned companies

Climate Change Programme Loans

Clean Development Mechanism

certified emission reductions

Conference of the Parties (to the UNFCCC)

civil society organisation

Dewan Nasional Perubahan Iklim

National Climate Change Council

Dana Reboisasi

Reforestation Fund

Food and Agriculture Organization of the United Nations

Financial Action Task Force

Forest Carbon Partnership Facility

Fauna \& Flora International

free, prior and informed consent

Global Climate Change Alliance

greenhouse gas

Government of Indonesia

Hutan Produksi Konversi

Conversion Production Forest

Indonesia Climate Change Trust Fund

Indonesian Forest Climate Alliance

Indonesia Green Investment Fund

Iuran Hak Pengusahaan Hutan

Forest Concession Fee 
IPK

\section{IUPHHBK-HT}

IUPHHK-HA

IUPHHK-HT

IUPHHK-RE

IUPHHK-HTR

JICA

KPK

LoI

$\mathrm{MoF}$

MPR

MRV

Nastra

NGO

ODA

PEP

PES

PPATK

PSDH

REDD+

R-PP

UKP4

UNCAC

UNDP

UNFCCC
Ijin Pemanfaatan Kayu

Timber Use Permit

Ijin Usaha Pemanfaatan Hasil Hutan Bukan Kayu - Hutan Tanaman non-timber forest product collection permit in plantation forests

Ijin Usaha Pemanfaatan Hasil Hutan Kayu - Hutan Alam

logging concession

Ijin Usaha Pemanfaatan Hasil Hutan Kayu - Hutan Tanaman

plantation forests

Ijin Usaha Pemanfaatan Hasil Hutan Kayu - Restorasi Ekosistem ecosystem restoration concession

Ijin Usaha Pemanfaatan Hasil Hutan Kayu - Hutan Tanaman Rakyat community plantation forests

Japan International Cooperation Agency

Komisi Pemberantasan Korupsi

Corruption Eradication Commission

Letter of Intent (between Indonesia and Norway)

Ministry of Forestry

Majelis Permusyawaratan Rakyat

People's Consultative Assembly

monitoring, reporting and verification

REDD+ National Strategy

nongovernmental organisation

official development assistance

politically exposed person

payments for environmental services

Pusat Pelaporan dan Analisis Transaksi Keuangan

Financial Intelligence Unit

Provisi Sumber Daya Hutan

Forest Resource Rent Provision

reducing emissions from deforestation and forest degradation and enhancing

carbon stocks

Readiness Planning Proposal

Unit Kerja Presiden bidang Pengawasan dan Pengendalian Pembangunan

Presidential Working Unit for Supervision and Control of Development

United Nations Convention Against Corruption

United Nations Development Programme

United Nations Framework Convention on Climate Change 


\section{Acknowledgements}

This paper was prepared for the United Nations Office on Drugs and Crime in Indonesia. The authors would like to thank the Royal Norwegian Embassy in Jakarta for their financial support for this publication. The authors are indebted to a number of individuals who provided input and assistance for the report. We would like to thank all the participants at the consultation meetings held 22 December 2010 and 28 March 2011. Ajit Joy provided thorough feedback and comments on early drafts. We would also like to thank officials at the Directorate of Forest Production Development, the Forestry Research and Development Agency of the Ministry of Forestry, the Corruption Eradication Commission and the Supreme Audit Agency for providing feedback and useful material. We would also like to thank Sally Atwater and Imogen Badgery-Parker for their thorough editing of final drafts, and CIFOR's publishing unit for typesetting and final preparation of the text. 



\section{Introduction}

Reducing emissions from deforestation and forest degradation (REDD) is a mechanism designed under the United Nations Framework Convention on Climate Change (UNFCCC) to enhance the role of forests in curbing climate change (UNFCCC 2007). The UNFCCC and its bodies have expanded the concept to include forest conservation and human activities that increase carbon stocks, or REDD+ (UNFCCC 2007, 2009). REDD+ has the potential to alter the incentives for deforestation and land use change and instead to encourage sustainable forest management.

Significant official development assistance (ODA) has already been committed to create the policy conditions for REDD+ and demonstration projects in forest-rich tropical countries, including Indonesia. The hope is that eventually ODA will be replaced by payments for reduced carbon emissions in a fully operational compliance market for forest carbon credits. In the meantime, investors are acquiring and governments are designating - large land areas in preparation for a REDD+ regime.

Without binding international agreements under the UNFCCC in place, REDD+ is evolving as a voluntary, bilateral or multilateral mechanism. Unclear REDD+ rules, potential for significant financial gain and weak governance in many of the tropical countries involved are giving rise to suspicions that possible speculative processes, corruption and malpractices may proliferate. Such practices range from violation of forest-dependent people's rights and livelihoods to increased deforestation and manipulation of baselines, carbon emissions reports and accounts. Even though Indonesia has demonstrated its commitment to improving governance and reducing corruption, concerns remain that old patterns and governance failures will be repeated in this new REDD+ context.

This paper aims to provide an analysis of the risk of corruption in REDD+ readiness activities, and the conditions that may influence potential outcomes in Indonesia. The intention is to inform, first and foremost, the government of Indonesia (GoI) and its efforts in building the policies and institutions for REDD+, so that adequate steps can be taken to remove barriers and reduce risks. As Indonesia is at the forefront in REDD+ policy reform and institutional design, it is hoped the analysis will also inform other forest-rich tropical countries and the donor community.

Given its purpose and scope, this paper pays significantly more attention to weaknesses that can affect REDD+ than to Indonesia's progress in curbing corruption and other associated crimes in the forestry sector. It focuses on the readiness phase - when tropical countries are preparing for REDD+ implementation - because this is the period during which policies, institutions, systems and processes are designed. These will influence the presence or absence of risks and conditions for corruption in subsequent phases.

The paper is structured as follows. Section 2 summarises the Gol's main undertakings in preparing the country for REDD+. Section 3 offers background information about Indonesia's forests and governance, reviews the general risks of corruption in REDD+ and highlights efforts to curb corruption, including the involvement of banks in preventing money laundering. Section 4 identifies the risks of corruption in the REDD+ policymaking process, paying special attention to the planned moratorium aimed at reducing forest conversion and the efforts to close regulatory loopholes and data gaps. It discusses how these efforts will support forest land use policies and clarification of jurisdictions and rights over forests. Section 5 looks at progress and gaps in cross-agency coordination. Section 6 discusses experience in climate financing in Indonesia, experience in the management and distribution of funds, and the role of banks. Section 7 reviews REDD+ benefit sharing, with particular attention to the discussion on the Ministry of Forestry (MoF) regulation on revenue sharing from voluntary carbon markets and payments for environmental services. Section 
8 discusses the REDD+ project implementation framework, focusing on experiences with licensing processes for forest concessions and permits, the types of concessions for forest use and REDD+ and the opportunities for corruption and their likely outcomes. Section 9 considers lessons from current practices in forest tax and production report reconciliation, the involvement of multiple agencies at various scales and the risks of corruption in REDD+. Section 10 summarises the main conclusions and provides some recommendations for priorities in addressing current weaknesses.
The paper is based on an analysis of relevant legislation, interviews with agency officials, literature reviews and media reports. Given the sensitivity of the topic, interviewees are not named. Their agency affiliation and the time of the interview are given instead. Research for this working paper drew extensively from print media, primarily in Indonesia but also globally, because REDD+ events are very recent and not all official documents are available. Many of the decisions and the processes discussed here are highly dynamic; by the time this paper is published, circumstances are likely to have changed. 


\section{REDD+ in Indonesia}

The GoI, aware of the benefits that REDD+ can bring to Indonesia, has become a major participant and contributor to the international REDD+ negotiations, and its role in shaping decisions on REDD + has been widely acknowledged (Jakarta Post 2010b, Republika 2010a, Investor Daily 2010, Antara 2010b). The GoI is introducing a wide range of national policies to create the policy environment for REDD+. Multiple demonstration projects are also underway.

Indonesia has selected what is known as a 'nested approach' to REDD+. A nested approach is the most flexible mechanism for implementing REDD+, compared with a purely national or a purely subnational approach. Under this approach, the national government could set up a national accounting framework, establish a nationwide monitoring system and implement certain policy reforms. At the same time, REDD+ activities could take place at the subnational level and be led by local/regional governments, communities, nongovernmental organisations (NGOs) or private developers. The approach creates a system in which REDD + credits are generated by projects and governments, thus maximising the potential of both (Angelsen et al. 2008, Terra Global Capital 2010, The Nature Conservancy and Baker \& McKenzie 2010).

Several donors, including Norway, UN-REDD, the World Bank's Forest Carbon Partnership Facility (FCPF), the United States, Australia and the European Union, have offered support (Antara 2010a, 2010c, 2010d, Jakarta Globe 2010d, Kompas 2010f, Brown and Peskett 2011). Norway is perceived as the biggest donor, pledging in May 2010 US\$1 billion for both the readiness and the implementation phases of REDD+. Activities marked for funding during the first phase include establishing an Indonesian REDD+ agency, developing a comprehensive national REDD+ strategy, implementing an interim funding instrument, developing a monitoring, reporting and verification (MRV) framework, selecting a pilot province and implementing a 2-year moratorium on new concessions on natural forests and peatland, commencing in 2011 (LoI 2010). With donor support and its own resources, the GoI has moved to create the policy and institutional framework for REDD+ during the readiness phase, which involves a wide range of policies, measures and pilot activities.

The intensive work underway is depicted in Table 1, with the following observations.

1. Efforts to improve cross-agency coordination started almost 5 years ago and have led to the formation of several coordinating bodies with similar mandates.

2. Development of strategies and policies started later than coordination and is still ongoing. Some emerging strategies propose long-term reforms, whilst others address issues related to implementation.

3. In 2010, the GoI focused its efforts primarily on proposing policies and measures in support of REDD+ implementation and on preparing a reference emission scenario, the accounting system and MRV.

4. Numerous demonstration or pilot projects are already in place or being developed and some rules regarding REDD+ projects have been set. 
Table 1. REDD+ readiness in Indonesia: Policy and institutional framework

\begin{tabular}{l}
\hline Decision or activity \\
Coordination and management \\
Indonesian Forest Climate Alliance (IFCA) \\
National Climate Change Council (Dewan \\
Nasional Perubahan Iklim; DNPI)
\end{tabular}

National REDD+ working groups (WG)

REDD+ Task Force/UKP4

\section{Status}

Formed in 2007. IFCA is a forum for communication, consultation and coordination of stakeholders working on forest and climate change in Indonesia. IFCA is coordinated by the Ministry of Forestry (MoF).

Formed in 2008 as a cross-agency coordination body. The DNPI is led by the President.

Initially formed in 2009 and chaired by the MoF. A decision was made in June 2010 to establish 3 working groups: (1) WG for the development of the REDD+ National Strategy, led by Bappenas (National Development Planning Agency); (2) WG to design and establish a special agency to coordinate the development and implementation of REDD+, an independent MRV agency and financing instruments, led by UKP4 (the Presidential Working Unit for Supervision and Control of Development); and (3) WG leading activities in the REDD+ pilot province, led by the MoF (MoF 2010).

Convened in September 2010 by Presidential Decree as a crosssectoral, cross-agency coordinating mechanism for implementation of the Letter of Intent (Lol) with Norway. The task force is led by the head of UKP4. It was expected to complete commitments with Norway by the end of 2010, although the deadline was extended until the end of June 2011. As the REDD+ Task Force did not complete all of its tasks, the President issued another Presidential Decree to establish another REDD+ Task Force to work until December 2012.

\section{Some REDD+ framework policies}

Readiness Planning Proposal (submitted to the FCPF)

National Strategy on REDD Readiness Phase in Indonesia

REDD+ National Strategy (with UN-REDD)
Prepared by the MoF and submitted to the FCPF in May 2009; assessed by the FCPF in June 2009; Indonesia selected as a Forest Investment Program pilot country.

Draft, prepared by the MoF in 2009.

Prepared by Bappenas (August 2010 - August 2011). Latest revised draft was released in August 2011. Input from regional consultations and from national and international consultation meetings has been considered and incorporated into the new draft. The new Indonesia REDD+ Task Force is now responsible for finalising the REDD+ National Strategy. President will sign it into Presidential Decree once it is finalised.

\section{REDD+ implementation policies and measures}

Moratorium limiting conversion of forests

Forestry sector review
Announced by the President in May 2010. On 20 May 2011, the President signed Presidential Instruction No. 10/2011 on moratorium of the issuance of new licences on primary forests and peatland. Exceptions are given to (1) applications for permits that have received in-principle approval from the Minister of Forestry; (2) implementation of national development that is considered vital, such as geothermal, oil and gas, electricity, land for rice and sugarcane; (3) extension of existing permits; and (4) permits for ecosystem restoration concessions.

Conducted in 2010 by the Corruption Eradication Commission (KPK) to identify regulatory, institutional, operational and capacity loopholes and weaknesses. 


\begin{tabular}{ll}
\hline Decision or activity & Status \\
\hline Clarifying boundaries, permits and title & $\begin{array}{l}\text { The Gol is working on mapping, demarcation and classification of } \\
\text { forest types and generating data on permits and titles. }\end{array}$ \\
MoF Permenhut P.36/Menhut-II/2009 & $\begin{array}{l}\text { Defines distribution of carbon revenues across scales and } \\
\text { participants but has been contested by the Ministry of Finance. }\end{array}$ \\
$\begin{array}{ll}\text { UN Development Programme (UNDP) grant } \\
\text { management facility (ICCTF) and other climate } \\
\text { finance arrangements }\end{array}$ & $\begin{array}{l}\text { Interim arrangements made for management of some donor } \\
\text { support including the Norway grant. Discussions about the design } \\
\text { are ongoing. Options include oversight by the President's Office, an }\end{array}$ \\
$\begin{array}{l}\text { international Advisory Committee or a Steering Committee. A phase- } \\
\text { in approach is likely. Other finance arrangements are also being put } \\
\text { in place to leverage public and private finance. }\end{array}$
\end{tabular}

\section{Decisions and activities related to REDD+ project implementation}

MoF Permenhut P.68/Menhut-II/2008

MoF Permenhut P.30/Menhut II/2009

Selection of pilot province as per agreement with Norway

Demonstration and pilot projects

\section{Reference levels, accounting and MRV}

Development of reference scenario

National accounting system

Monitoring, reporting and verification (MRV)
Regulates demonstration activities for carbon emission reductions from deforestation and forest degradation.

Commits Indonesia to a nested approach and defines approval, criteria, location and forest types eligible for REDD+ projects.

Central Kalimantan announced as pilot REDD+ province by President Yudhoyono during a Cabinet meeting on 10 December 2010.

About 44 demonstration activities and pilot projects underway.

Initial work on development of reference scenario completed and challenges identified, but no comprehensive report has been published on the system with the nested approach.

Work continues to establish a national carbon accounting system, adapted from the Australian accounting system. Director General of Forest Production Development Decision P.3/VI-Set/2010 explains how to monitor, report and verify forest use by concession holders and provides a methodology for carbon accounting for production forests, developed by the MoF.

Letter of Intent with Norway requires Indonesia to establish an independent national MRV agency. The UKP4 has proposed that MRV agency be under international and national steering committees but directly supervised by the national advisory committee; the agency will likely be under the President's Office. 


\section{REDD+, corruption and anti-corruption efforts in Indonesia}

Indonesia has more than 90 million ha of forest cover, as well as extensive peatlands. Deforestation is the largest contributor to Indonesia's greenhouse gas emissions. REDD+ promises to create a potentially significant role for Indonesia's forests in mitigating climate change, as well as a new source of revenue for the country. However, it will operate in the existing forest governance context. The GoI is aware of the risk of corruption and is taking steps to curb it.

\subsection{The potential for corruption in REDD+}

Corruption is generally defined as the abuse of public office or entrusted power for private gain (World Bank 1997, Lambsdorff 2007). In Indonesia, the definition of corruption is slightly wider, as an unlawful act for private gain that results in losses to the state. With this definition, the perpetrators of corruption go beyond government officials and offices. With the emphasis on violation of the law and losses incurred because of that violation, anyone, whether categorised as government official or office, private entity or individual, can be convicted of corruption (Law No. 31/1999).

Corruption can take many forms, including bribes, fraud, favouritism, nepotism, extortion, abuse of power and embezzlement (Graycar and Villa 2011, Morris 2011, Wijayanto 2009). Depending on their scale and outcome, such acts can be classified as petty or grand corruption. Petty corruption is practised on a smaller scale; it usually involves relatively small amounts of money, including bribery (grease money or speed payments). The public servant abuses his/her position by accepting a benefit for what is a routine transaction or approval. The direct victim of this abuse of power is the citizen. Grand corruption is the most dangerous and covert type of corruption, as it compromises policymaking and its design and implementation. It occurs when public officers in high positions, in the process of making decisions of significant economic value, accept bribes or kickbacks for ensuring that decisions benefit specific groups. Grand corruption occurs at financial, political and administrative levels (Bracking 2007, Campos and Bhargava 2007, Wijayanto 2009). Conditions that facilitate corruption are the concentration of decision-making power, closed-door decision-making, large amounts of public capital involved in projects, vested interests and politically connected networks, weak rule of law, poorly paid civil servants and a weak civil society. These conditions are associated with information deficits, weak accountability mechanisms and weak judicial independence, conflicts of interest and others. Corruption also flourishes when rules and laws are complex, confusing or contradictory, and difficult and expensive to implement. Weak institutional capacity facilitates it (Johnston 2005a, 2005b, Karklins 2005, Sarre et al. 2005, Tarling 2005, UNODC and CSD 2005, UNODC 2006).

REDD+ will take shape in 3 principal phases. During the readiness phase, tropical countries build the institutional and policy framework. During the implementation phase, national strategies and measures are put into effect. In the third phase, performance-based payments are made for any carbon emission reductions achieved (UNDP 2010, Bofin et al. 2011). Potential corruption in the readiness phase targets the national policymaking process and is therefore likely to involve powerful individuals and groups, such as politicians, logging companies, agribusiness and possibly the military, that can harness the opportunities presented by REDD+ to 'legalise' corruption (UNDP 2010). Vested interests can do so by influencing the design of REDD+ policies and institutions to maintain flaws and opportunities for benefiting later by legal, semi-legal or corrupt means. Therefore, corruption in the readiness phase will influence the level of risk that corruption will occur in later REDD+ phases. The areas susceptible to corruption include setting baseline levels, reconciling the accounting between project and national credits in a 'nested' approach (a system of national accounting with subnational implementation through projects) and the longterm MRV of REDD+ initiatives. Corruption and fraud in setting baseline levels will affect the 
amounts a country receives for performance in reducing deforestation and forest degradation or pays for carbon. This will primarily affect international transfers and accounting. The reconciliation of project and national accounts is critical for the establishment of the national accounting system. The incentives to tamper with setting baselines, reconciling accounts and MRV could grow as REDD+ develops (Brown 2010). Specific attention is needed to prevent REDD+ being exploited by companies with poor social and environmental track records at the expense of local communities and indigenous people. It is also important to ensure that REDD+ focuses on conservation rather than conversion, and to prevent uncontrolled land grabs (Greenpeace 2010, Guardian 2010, Bonfante, et al. 2010).

The people most harmed by corrupt REDD+ practices may be the indigenous and local communities dependent on forests. The rush to acquire land for REDD+ may further deprive them of their rights and livelihoods. Other victims of corruption are the national economy of the recipient country, the forests themselves, the global climate and the donors funding REDD+.

\subsection{The forestry sector and anti- corruption efforts}

Indonesia is a country rich in tropical forests. Forests and forest land are a vast but declining source of natural resources ranging from timber and minerals to peatland. These resources and wealth are attractive and, when combined with the country's generally weak governance, create opportunities for corruption and fraud. Corruption and money laundering in the forestry sector are associated primarily with illegal logging. The 2010 International Narcotics Control Strategy Report concludes that money laundering in Indonesia is connected to illegal logging and corruption (US Department of State 2010).

The forest-related wealth in Indonesia has created specific factors and interests and has made the forestry sector highly susceptible to corruption in a number of ways. First, large projects involving billions of dollars of public funds or capable of generating considerable wealth operate in the forestry sector. An example from the recent past is the Reforestation Fund (Dana Reboisasi; DR) and its misuse for the enrichment of elites (Barr et al. 2009). Second, concessions and permits for activities in forests offer a significant source of revenues worth billions of dollars. These, although not public funds per se, constitute public wealth that offers enrichment. The magnitude of this wealth and who will use it are decisions made by public officials, who thus become likely targets for bribes to combine 'according to rule' or 'against the rule' corruption with totally legitimate practices. Third, illegal logging and associated corruption have long been acknowledged as a serious problem and driver of deforestation in Indonesia and have resulted in substantial losses of government revenue (Brown et al. 2005, MoF 2007).

Corruption in the forestry sector is rampant and the sector's reputation is tarnished. In the words of Chandra M. Hamzah, a deputy chairman of the Corruption Eradication Commission (KPK), 'The forestry sector is a source of unlimited corruption' (Jakarta Globe 2010b, Lang 2010a) The existence of long-standing close ties between certain companies especially logging companies - and state elites, along with closed-door decision-making in the forestry agencies, has aroused suspicions and produced some evidence that corruption reaches high levels of power (Barr et al. 2009, Eshelman 2010, Jakarta Globe 2010b, Republika 2010b). Conditions facilitating corruption within the forestry system itself are compounded by corruption in other agencies and systems, such as the justice system, which contributes to the high levels of corruption in the forestry sector (MoF 2009).

The success of efforts to curb corruption in the forestry sector specifically depends on anticorruption efforts generally. The Reformasi Era marked the beginning of Indonesia's efforts to improve governance and curb corruption. Early in the era, the People's Consultative Assembly (Majelis Permusyawaratan Rakyat; MPR), Indonesia's highest state institution, issued a decree on clean state administration free from corruption, collusion and nepotism (TAP MPR No. XI/MPR/1998). This and a subsequent decree (TAP MPR No. VIII/MPR/2001 on recommendations for policy directions on the eradication and mitigation of corruption, collusion and nepotism) form the foundation for anticorruption laws in Indonesia. 
Indonesia ratified the United Nations Convention Against Corruption (UNCAC) in 2006, has adopted various laws and regulations and has established agencies to ensure implementation (Annex 3). It has also implemented standards, principles and recommendations by the Financial Action Task Force (FATF). The legal framework covers not only corruption but also money laundering, mutual legal assistance and financial institutions. In 2006, FATF removed Indonesia from the list of high-risk countries (FATF 2006). In 2010, using the FATF guidelines, the US Financial Crimes Enforcement Network recognised Indonesia's high-level political commitment to close regulatory loopholes by criminalising money laundering and terrorist financing and made some recommendations for improvement (FinCEN 2010).

Law No. 20/2001 defines corruption in a broad sense, including both public and private individuals as perpetrators and describing a wide range of offences, including state losses, embezzlement, tax evasion and acceptance and giving of gifts. Indonesia's anti-money laundering laws, first adopted in 2002, were expanded when Parliament included forestry crimes and made proceeds of forestry crimes subject to both anti-money laundering laws and anti-corruption laws (Law No. 8/2010; Gatra 2003).

Indonesia has also created 2 specialised, independent agencies tasked with law enforcement, in addition to existing internal and external audit agencies such as the internal control unit (Inspektorat Jenderal) within ministries and the Supreme Audit Board (Badan Pemeriksa Keuangan; BPK). The Corruption Eradication Commission (Komisi Pemberantasan Korupsi; KPK) and the Financial Intelligence Unit (Pusat Pelaporan dan Analisis Transaksi Keuangan; PPATK) have essential roles in curbing corruption and preventing or limiting money laundering. The role of the BPK as the sole auditor for government agencies at all levels has been strengthened and the BPK carries out regular performance or special purpose audits in the forestry sector. The KPK's mandate is to coordinate and supervise relevant agencies, prevent, investigate and prosecute corruption, and monitor government agencies and officials (Law No. 30/2002). The KPK has made significant achievements, securing conviction in $100 \%$ of cases in the period 2005-2008 (KPK
2008, Bolongaita 2010). However, there are forces attempting to weaken the KPK in carrying out its mandate to spearhead anti-corruption efforts (Box 1).

The PPATK's core functions are to manage data and information, analyse suspicious financial transaction reports, prevent and combat money laundering, and monitor compliance, particularly by financial institutions (Law No. 15/2002; Annex 4). Under a new law issued in 2010 (Law No. 8/2010), the KPK, customs investigators and the National Narcotics Agency, in addition to the National Police and the Attorney General's Office, are eligible to receive 'suspicious transaction report' analyses from the PPATK. The law also gives the PPATK broader authority to prevent money laundering by requesting financial institutions to stop suspicious transactions (Law No. 8/2010; PPATK 2010). Moreover, the PPATK has issued a regulation specifically regarding reporting of money laundering in the forestry sector (PPATK Decree No. Kep-2B/1.02/PPATK04/06 on Guidelines on Providing Information on Money Laundering in Forestry and Biodiversity Conservation Sector of 2006). The guidelines specify the types of predicate crimes in the forestry sector, the kinds of information to be provided to the PPATK and examples of money-laundering activities in the forestry sector.

Indonesia's anti-corruption and anti-money laundering legal and institutional framework has the following characteristics.

1. It closely follows the UNCAC requirements and implements FATF principles and recommendations.

2. It is comprehensive and encompasses a range of aspects, stages and entry points of corruption and associated crime.

3. It has been rapidly evolving, with the most recent law passed in October 2010.

4. New institutions, the KPK and the PPATK, have been created with special mandates to curb corruption and money laundering. However, they are relatively new and are still building their capacity.

5. Regulations linked to UNCAC requirements transparency, reporting and auditing standards to prevent corruption by industry and to encourage civil society participation to help reduce corruption - exist but are relatively weak (see Annex 4). 


\section{Box 1. Challenges to anti-corruption initiatives in Indonesia: The case of the KPK}

Since its establishment, the KPK has encountered numerous challenges, starting from the annulment of articles on the anti-corruption court by the Constitutional Court in 2006 (1) to recent debates in the House of Representatives on the number of candidates for the position of KPK commissioner.

The first major blow to the KPK came in the form of allegations against Antasari Azhar, who was chairman of the KPK from 2007 to 2011. Azhar was charged with arranging the murder of Nasrudin Zulkarnain; the Supreme Court found him guilty and sentenced him to 18 years in prison (2). Azhar has maintained his innocence and submitted new evidence in the hope of proving that he is not guilty of the alleged crime.

This was followed by accusations of misuse of authority and extortion levelled against 2 KPK commissioners, Chandra M. Hamzah and Bibit Samad Rianto, in relation to a case of bribery in the procurement of an integrated radio communication system at the Ministry of Forestry. Anggodo Widjojo, a defendant in the case, testified that Chandra and Bibit received bribes from him. The Indonesian National Police claimed that they had evidence that Chandra and Bibit had received bribes. However, it has been alleged that that evidence was fabricated (3). In December 2009, the State Prosecutor signed 2 decisions (SKPP) to terminate the investigation of Chandra M. Hamzah (4) and Bibit Samad Rianto (5). Anggodo later challenged these SKPPs. In April 2010, the South Jakarta Court ruled in favour of Anggodo, meaning that the case has been reopened.

A recent challenge to the KPK was the rejection by the House of Representatives of the Constitutional Court Decision ruling that Busyro Muqoddas, the new KPK chairman replacing Antasari Azhar, could continue his tenure until 2014. The House of Representatives argued that Busyro, who was appointed in 2010, was only a substitute for Azhar, whose tenure ended in 2011 and so could only serve as a commissioner until 2011. This debate affects the process of electing new KPK commissioners in 2011. Under the law, the House of Representatives chooses 5 commissioners to lead the KPK. To select these 5 commissioners, the President must submit a list of 10 candidates to the House. As one commissioner already is in place, the President submitted only 8 names, which is in line with the Constitutional Court decision. Anti-corruption society also rejected the notion that the President should submit 10 names, because they believe that including the two extra names on the list contravenes anti-corruption efforts in Indonesia. However, the House of Representatives demanded that the President submit 10 candidates instead of 8.

Sources:

1. Constitutional Court Decision No. 012-016-019/PUU-IV/2006, 19 December 2006

2. Supreme Court Decision No. 1429 K/PID/2010

3. $14^{\text {th }}$ International Anti-Corruption Conference 2010 Anti-corruption agencies: achievements, threats and challenges in diverse environments. Bangkok.

4. Surat Keputusan Penghentian Penyidikan (SKPP) No. Tap-01/0.1.14/Ft.1/12/2009

5. SKPP No. Tap-02/0.1.14/Ft.1/12/2009

The banking sector in Indonesia is also involved in efforts to curb corruption and money laundering. It underwent drastic reform after the crisis of the late 1990s. Bank Indonesia, the central bank, gained comprehensive authority over banks, and its supervisory system began to function, as did individual banks' risk management systems and efforts to build risk management capacity (Sato 2005).

Bank Indonesia has adopted regulations for implementing standards for 'know your customer', due diligence and enhanced due diligence, and it has set requirements for adequate staffing and independence of departments responsible for preventing money laundering (e.g. compliance departments, independent control units and legal units) by commercial banks. To ensure the enforcement of these and other provisions, Bank Indonesia has set penalties for a commercial bank's failure to implement them. Its efforts have been strengthened via circulars and rules adopted in 2009 and 2010 (BI Regulations No. 11/28/2009, No. 12/03/2010; BI Circular No. 11/31/DPNP 2009).

Despite the numerous regulations on due diligence, to date there have not been any anti-money laundering cases or convictions in the forestry sector. 
The reason may be that the regulations are relatively new or that the banking sector needs to better identify high-risk customers, politically exposed persons (PEPs) and suspicious financial transactions. However, corruption cases using other instruments and regulations have been brought to court. These corruption cases involved PEPs, such as a governor or a regency head (see Box 2).

In 2010, the KPK announced that it would investigate potential corruption in 4 sectors, one of which was forestry (KPK 2010a). The KPK's review covered $\mathrm{MoF}$ regulations, institutions, operations and human resources (KPK 2010b, 2010c). It found significant regulatory uncertainty and inconsistency, which facilitate mismanagement, misuse and corruption.
In particular, the KPK found uncertainty and conflicting regulations for defining forest areas in 4 laws and regulations affecting the Forest Zone: Law No. 41/1999, Government Regulation No. 44/2004, Minister of Forestry Decree (SK Menhut) No. 32/2001 and Ministry of Forestry Regulation (Permenhut) No. 50/2009. The KPK analysis indicates that companies involved in illegal logging and illegal mining lawsuits can exploit that regulatory uncertainty to successfully defend any charges. Moreover, regulatory uncertainty or conflicting definitions negatively affect spatial planning by provinces and districts.

In recent years, Indonesia has improved its ranking in performance in curbing corruption, as shown by both

\section{Box 2. Curbing corruption in the forestry sector: High-profile cases involving PEPs}

\section{H. Suwarna Abdul Fatah (former governor of East Kalimantan)}

Suwarna was involved in issuing permits to open 1 million ha of land for oil palm plantations in Berau, East Kalimantan, for Martias, the owner of Surya Dumai Group in 2003-2008. His role was in waiving the company's obligation to provide a bank guarantee. The provision of a bank guarantee is a requirement for obtaining a timber use permit for land opened for oil palm development. For this crime, Suwarna was accused of enriching Surya Dumai Group, causing state losses of Rp 346.8 billion.

He was charged with enriching himself, other people or a corporation causing state losses and for abuse of power or authority, in violation of Law No. 31/1999 and Law No. 20/2001 on corruption eradication. He was sentenced to 4 years in prison and fined Rp 200 million.

Tengku Azmun Jaafar (former regent of Pelalawan, Riau)

During 2001-2006, Jaafar issued 15 timber plantation licences in Pelalawan Regency, Riau. A KPK investigation found that the companies that received the licences did not meet the criteria for forestry enterprises. The KPK also found that the owners of 7 of the 15 companies have affiliations or a family relationship with Jaafar. By granting the licences, Jaafar violated Ministry of Forestry Regulation No. 10.1/Kpts-11/2000 on guidance for granting timber plantation permits and Ministry of Forestry Regulation No. 21/Kpts-1I/2001 on Criteria and standards for licensing timber plantations in production forests. In its investigation, the KPK also found that the flow of money to Jaafar amounted to US\$100,000.

Jaafar was charged with enriching himself, other people or a corporation causing state losses and for abuse of power and authority, in violation of Law No. 31/1999 and Law No. 20/2001 on corruption eradication. He was sentenced to 11 years in prison and fined US $\$ 56,000$ by the Supreme Court. He was also sentenced to pay restitution to the state to the amount of $\$ 1.4$ million.

Marthen Renuw (former head of the General Investigation Unit of the Police Office of Papua) Marthen Renuw was accused of receiving bribes in 2002 and 2003. The bribes were given by officials from 2 forestry companies, Marindo Utama Jaya and Sanjaya Makmur. These companies carried out logging in Bintuni-Manokwari with unlicensed heavy equipment. Renuw was supposed to investigate and process the crime. However, the police later found that he received bribes from the companies to the value of approximately US\$110,000 (Rp 1.1 billion). He was charged with receiving bribes in violation of Law No. 31/1999. He was also charged with money laundering, in violation of Laws No. 15/2002 and No. 25/2003. The court found Renuw not guilty of all charges. 
the World Bank's Worldwide Governance Indicators and Transparency International's Corruption Perception Index (Transparency International 2010, World Bank 2010). Nevertheless, corruption permeates all aspects of Indonesian society and is an ongoing challenge for anti-money laundering and counterterrorist financing implementation (US Department of State 2010).
In sum, the GoI has been moving forward with anti-corruption initiatives, with several notable achievements. However, given the deeply rooted weak governance within the forestry sector, the risk of corruption in REDD+ in Indonesia is significant. At least in the short term, REDD+ will operate in a forest governance context that offers many opportunities for corruption. 


\section{REDD+ policymaking}

The REDD+ policy formulation process in Indonesia is highly dynamic and multi-layered, and it has become more so with the signing of the Letter of Intent (LoI) and partnership agreement with Norway. The President has announced his commitment to reversing unsustainable practices and placing Indonesia on a path towards a more secure and sustainable development approach, by adopting 'pro-poor, pro-job, pro-growth and proenvironment' objectives and translating them into national development targets and selected priority implementation programmes (GoI 2010, Jakarta Post 2010f).

Several policies may shift Indonesia's development path towards a more sustainable future and shape the success of the REDD+ readiness phase. Changing direction, however, involves tough decisions that will affect powerful interests and will certainly meet with resistance. Profound reforms are necessary and will not be easy, especially as corruption and fraud may limit or obstruct their introduction and implementation.

The greatest risks in the REDD+ policymaking process are that grand corruption may occur and that policies developed and adopted now will favour specific interests in the long run.

\subsection{Framework strategies and long- term reforms}

Three basic documents establish the framework for REDD+: the draft Readiness Planning Proposal (R-PP), submitted by the MoF to the FCPF in May 2009; the draft National Strategy on REDD Readiness Phase in Indonesia (MoF 2009) and the National Strategy (Nastra), developed by Bappenas in 2010, with the most recent draft released in August 2011 (FCPF 2009, MoF 2009, GoI 2010).

The FCPF review of the R-PP recommended that the GoI carry out a strategic environmental and social assessment of the proposed REDD+ programme; ensure strong coordination amongst stakeholders by involving related ministries and paying special attention to forest communities, indigenous people and smallholders in defining benefit-sharing schemes and carbon, land and asset ownership; harmonise REDD+ implementation with new and existing regulations; and integrate demonstration activities into the wider REDD+ strategy development (FCPF 2009). The government has taken these recommendations seriously and is responding to them, primarily by increased efforts to engage stakeholders and improve cross-sector and crossagency coordination. For example, the Nastra has undergone a series of consultations with stakeholders (interview, Bappenas, January 2011), and the REDD+ Task Force has been formed to strengthen coordination (Presidential Decree No. 19/2010).

The draft National Strategy on REDD Readiness Phase in Indonesia (MoF 2009) acknowledges that the 'sustainability of forest resources is crucial' for Indonesia's development - indeed, that it is a question of survival. The value of forests is defined not only by their role in adapting to climate change but also by the extent to which the population and economy depend on them. About 48 million people live in and around Indonesia's forests, with approximately 6 million directly dependent on forests. Forest commodity exports accounted for US $\$ 5$ billion in 2005, making a notable contribution to GDP (MoF 2009).

The draft of the REDD+ National Strategy (Nastra), originally developed by Bappenas in 2010 and currently under the coordination of the Presidential Working Unit for Supervision and Control of Development (UKP4), outlines ways to improve management of the forestry sector, implement sustainable development and reduce impacts on forests by the timber, oil palm, agriculture and mining sectors. The Nastra is defined as a 'living' document that will incorporate new insights and inputs as REDD+ evolves. It will guide the development of realistic REDD+ action plans. The effectiveness of the Nastra depends on its integration into development planning and policymaking at 
national, provincial and district levels. Its architects acknowledge that success will also depend on broad consensus, support and involvement of all stakeholders (GoI 2010, Kompas 2010b, Lang 2010b, LoI 2010).

The Nastra cites land use and weak spatial planning as key underlying problems leading to deforestation, along with tenure problems, ineffective forest management, poor governance and weak law enforcement. The document includes 5 strategic measures to reduce greenhouse gas (GHG) emissions from land use, land use change and forestry, to increase carbon stocks, to ensure the sustainability of biodiversity and to increase the value and sustainability of forests' economic function. The measures are: to build a REDD+ institution; to review and strengthen policies and regulations; to launch strategic programmes such as sustainable landscape management, implementation of sustainable natural resource use, and conservation and rehabilitation; to change paradigms and the work culture; and to involve stakeholders particularly through free, prior and informed consent (FPIC), implementation of safeguards and benefit sharing. By changing land use patterns, improving land use planning and channelling development, the GoI can help reconcile the seemingly competing targets of $7 \%$ annual economic growth and its emission reduction targets of $41 \%$ below business as usual by 2020 . Implementing these strategies will involve some tough decisions and trade-offs and will require prioritisation.

\subsection{Forest land use}

The implementation of the government's commitment to 'pro-poor, pro-job, pro-growth and pro-environment' objectives and to sustainable development (GoI 2011) is dependent on a range of policies, amongst which land use policies and practices are key. On the one hand, sectors that make important contributions to GDP such as oil palm and mining rely on land. Demographic growth also intensifies pressures on land. On the other hand, sustainable and pro-environment development is unthinkable without the preservation of high-value forests, both for their carbon and for the wide range of other ecosystem services they provide.
Existing forest policies define 3 types of forest according to their use: production forest (butan produksi), a subset of which includes conversion production forest (butan produksi konversi; HPK); protection forest (butan lindung); and conservation forest (hutan konservasi) (Law No. 41/1999). In each type of forest, different activities are permitted, and presumably the condition of forests differs amongst types also. Production forests are areas designated for sustainable forest management and are expected to maintain forest ecosystems within the forest estate. HPK can be converted to other non-forest uses, such as agriculture, estate crops (e.g. coffee, oil palm, rubber) and settlements. The decision to release HPK from the forest estate is subject to an approval from the $\mathrm{MoF}$ based on proposals from industry or government. Once released, converted forest areas become subject to land use decisions that are largely the responsibility of local governments or the National Land Agency (Badan Pertanahan Nasional; BPN) (MoF 2009; Law No. 41/1999).

It is important to note that, at the same time, another process is taking place, which may have implications for forest land use. Law No. 26/2007 on spatial planning required all subnational governments to have prepared their spatial plans by the end of 2010; however, by September 2011, only 10 (out of 33) provinces had issued a Provincial Regulation on spatial planning (Direktorat Jenderal Penataan Ruang 2011). A Coordination Agency for National Spatial Planning (Badan Koordinasi Penataan Ruang Nasional), led by the Coordinating Ministry for the Economy, was established by Presidential Decision No. 4/2009. The MoF is one of the 10 members of the agency. The agency's tasks include aligning regulations on spatial planning, land use and natural resource use. In particular, harmonising provincial governments' proposed spatial plans with existing forest maps is a central issue requiring resolution.

The Nastra proposes reforms designed to change land use by the forestry sector and to reduce pressure on forest land by sectors such as agriculture and mining (GoI 2011). Even though the draft has not yet been adopted and implementation plans are yet to be prepared, the GoI is already taking steps to improve land use decisions in the forestry sector by reviewing and addressing weaknesses that prevent informed decisions and allow corruption, misuse and fraud. 
The KPK review in 2010 found major regulatory uncertainty and inconsistency, which are conducive to mismanagement, misuse and corruption in land use and land allocation decisions (KPK 2010c). Some regulatory inconsistencies and loopholes create conflicting authority between different levels of government and allow for different interpretations and discretionary decision-making. For example, between 2002 and 2009, the Ministry of Home Affairs alone issued some 1840 decrees abolishing regulations by subnational governments (Ministry of Home Affairs 2009). The ministry is currently reviewing a further 2678 decrees (Tempo 2011).

Inconsistencies and loopholes grant governments at different levels a certain amount of discretionary power. For example, decentralisation has given districts the authority to make certain decisions. These decisions by subnational governments frequently lead to forest conversion as they are driven by district governments' desires to raise revenue and support local development, or by pressure from communities or business to accelerate forest exploitation (Contreras-Hermosilla and Fay 2005). Unclear or conflicting authority, associated discretionary decision-making and possibilities for corruption have been known to lead to conversion of protected areas, over-logging, establishment of plantations on areas outside permits and other practices resulting in uncontrolled deforestation (Walhi 2011).

Forest land classification that supports sustainable development must be based on clear criteria for each forest type and for their allocation and conversion. Currently, various government documents and policies provide different sets of criteria for forest land classification, especially for conversion forests. On the one hand, the MoF REDD Readiness Phase strategy suggests that forests for conversion are those in Indonesia's lowlands, because they are more suitable for non-forest uses, such as oil palm development and other agricultural activities (MoF 2009). On the other hand, statements on the moratorium suggest that the intention is to restrict development to degraded land, and the Nastra outlines an agricultural and food security strategy that avoids clearing new forest land and seeks to improve productivity.
Accurate data and information are essential to support policies on REDD+ and development. Data on forest boundaries, forest condition and forest land use are critical for informed decision-making. At the moment, however, there are several incompatible data sets and maps. For example, according to MoF data, the forest cover in Indonesia spans 99 million ha, but according to Ministry of Environment data, it is 77 million ha (Brockhaus et al. 2010, Kompas 2010d). Over the years, Bappenas, regional and district authorities and other agencies have used different methodologies to develop spatial maps, and have consequently generated different information. The government asserts that 40 million ha of degraded land can be used for plantations, but it has never been made clear where this land is located. Independent research suggests that, in 1990, 46 million ha in 7 provinces and 302 districts was eligible for afforestation and reforestation under the Clean Development Mechanism (CDM) established by the Kyoto Protocol. This land was degraded at that time, and most of it probably still is; in fact, the area may have increased (Murdiyarso et al. 2006, Kompas 2010g).

The lack of accurate data on forests and land use and classification of forest areas hampers the formulation and implementation of a policy to protect high carbon value forests and channel investment into degraded forest land. Land classification influences the location and objectives of REDD+ projects as well as of development activities such as oil palm plantations. It defines which forest land is available for conversion and which should be protected, preserved or reforested.

Accurate data are also essential for establishing reliable baselines. In Indonesia, as in all other forestrich developing countries preparing for REDD+, baselines have not been set. The $16^{\text {th }}$ UNFCCC Conference of the Parties (COP 16) in Cancún in 2010 agreed that the CDM Executive Board would continue to develop and improve standardised baselines, including baselines for projects in forestry. These standards are likely to inform baselines set for REDD+, even if they are not directly adopted. COP 16 defined a 'standardised baseline' as a baseline established for a party or a group of parties to facilitate the calculation of emission reductions and 
removals and/or the determination of additionality ${ }^{1}$ (UNFCCC 2010). Therefore, obtaining accurate data on forest status is critical for determining Indonesia's baselines. However, as Indonesia is committed to a nested approach, baselines must also be established for projects. Accurate data and land classification are therefore important for both national and project baselines. Data inaccuracies - or absence - may allow massive deforestation to take place before baselines are established (Brown 2010).

Indonesia's 2nd National Communication to the UNFCCC reports deforestation levels that are significantly lower than those estimated by PEACE and the World Bank (MoE 2010, Verchot et al. 2010). Some concerns have been voiced internationally that forest-rich countries may overestimate deforestation levels before the start of the REDD+ regime. Doing so would enable them to manipulate baselines, overreport emissions and actually increase emissions. This would then allow both countries and project proponents to claim more reductions after REDD+ becomes operational in a compliance market. Indonesia's underestimation of deforestation rates may lead to loss of REDD+ revenues.

On 22 December 2010, the MoF presented its plan to create Guidelines for Forest Area Mapping, Forest Area Maps for Districts/Cities and Forest Management Units and to harmonise regulations (KPK official, interview 2011). The REDD+ Task Force and the MoF have announced that they are compiling forestry data and generating accurate maps but are having difficulties (Bisnis Indonesia 2010b, Kompas 2010d, KPK official, interview 2011). Special attention is being paid to mapping degraded areas and production forests (Jurnal Nasional 2010). Having such data will help accurately identify conversion forests for the expansion of sectors such as oil palm and pulp and paper. It will also support accurate classification of production forests for reforestation and timber plantation development eligible under REDD+.

1 CDM projects have to prove that investment in emission reductions or removals is additional to what the project proponent would have done otherwise. Additionality is also likely to be key in determining the eligibility of projects under a REDD+ regime.
Data on primary and high carbon stock forests are also critical both for establishing accurate baselines and for making decisions on the best places to restrict development.

Closing regulatory loopholes and generating data to support informed land use planning are important steps in changing land use patterns, but they are not sufficient by themselves. Other important and necessary measures in the short term are clarifying authority and adopting clear and consistent forest classification - and reclassification - criteria and processes, and revising spatial plans at all levels. However, land use patterns can change only if policies also adequately change incentives and behaviours in the long run.

Land use decisions in many forest-rich tropical countries occur in situations of insecure governance and corrupt natural resource allocation (Macqueen 2010). Closing regulatory loopholes and generating accurate data and maps are likely to improve security of governance. Making decisions public and improving transparency may be critical in limiting corruption and fraud in forest land classification and setting baselines.

\subsection{Rights and tenure}

Unclear or insecure tenure will be a critical obstacle to REDD+. The Nastra cites tenure issues as amongst the underlying problems leading to deforestation (GoI 2011). The 2009 MoF REDD Strategy for the Readiness Phase also acknowledges that community rights constitute one of the 2 contested areas of governance, the other being clarifying the role of district governments (MoF 2009). Unclear tenure may add to REDD+ transaction costs, increase uncertainty and act as a disincentive for investment. Projects may be compromised or undermined by claims and conflicts (Stern 2006, Cotula and Mayers 2009, Sunderlin et al. 2009). REDD+ benefits may not reach their ultimate intended target, that is, the party that holds the rights to the carbon and forest (Sunderlin et al. 2009).

Large areas of forest land in Indonesia are owned by the state under MoF jurisdiction. However, the state has failed to effectively implement its own regulations 
and laws, calling into question the legality of the forest estate and the jurisdiction and rights over it. For example, MoF Decree No. 32/2001 and MoF Regulation No. 50/2009 define how the MoF will implement the framework forestry law (Law No. 41/1999) and establish the boundaries (temu gelang) of the forest estate. In practice, the MoF has failed to do so in $88.2 \%$ of the forest area (MoF 2004, KPK 2010c). The KPK review also found problems with legal title and location of land claims (KPK 2010a, 2010c). Earlier studies found that legal rights and jurisdiction have not been clarified and are contested (Fay et al. 2000, Fay and Sirait 2005).

The lack of clear rules and titles and the inability of the central government to monitor and enforce the law have translated into local government initiatives that go well beyond their authority and have led to a loss of coherence in tenure policy. Decentralisation has increased the pressure for changes in the districts and intensified struggles for land as well as struggles for authority between central and district governments. The opportunity to establish claims over forest resources at district level has created numerous demands and conflicts (Contreras-Hermosilla and Fay 2005).

However, tenure problems go beyond clarifying the boundaries of forest land under $\mathrm{MoF}$ jurisdiction, recognising community and individual rights, clarifying roles of different government levels and generating data about legal title. They are also about who will ultimately make decisions and who will use and benefit from forests and the resources associated with them. They also concern how the competition for forests and land is resolved and in whose favour.

REDD+ is already competing with conventional sectors that are reliant on expansion into forests, such as oil palm, biofuels or agriculture, as suggested by the conflict surrounding the moratorium. However, REDD + may also encroach upon forests traditionally used by communities or indigenous peoples. The MoF claims that its initiatives to legally strengthen community access to customary land under forests designated as 'village forest' or 'community forest' protect communities against encroachment $(\mathrm{MoF}$ 2009). Experience with large-scale projects in Indonesia, however, provides abundant examples of encroachment leading to competing claims, conflicts or even violence (Sunderlin 2007, Forest Peoples Programme 2009). CDM examples in other countries show how projects intended to promote sustainable development and low-carbon choices led to conflicts with communities over land and rights and even resulted in physical violence against community leaders and destruction of homes and crops (International Rivers 2008). Experience with debt-for-nature swaps - a mechanism that emerged in the 1990s with the objective of preserving natural resources in developing countries, including forests - also indicates that it is essential to include local people in site-specific projects to ensure any degree of success (Deacon and Murphy 1997, Thapa 2000).

There are indications that REDD+ is already limiting indigenous communities' access to forests, according to Friends of the Earth Indonesia (Walhi). Walhi has requested that indigenous peoples be granted the right to reject or accept REDD+ projects in their area (Kompas 2010a). In response, Kuntoro Mangkusubroto, the head of the Presidential Working Unit for Supervision and Control of Development (UKP4), guaranteed that the rights of indigenous communities would be recognised and that they would benefit from REDD+ primarily through community empowerment programmes (Antara News Jawa Timur 2010). Through MoF Regulation P.36/Menhut-II/2009, the MoF has sought to ensure that forest-dependent communities receive a share of the benefits from REDD+ activities; however, the regulation has been challenged.

As past experience and studies show, there is an association between tenure security and livelihoods and incomes. Livelihood benefits are more likely to result from secure rights over land or resources (Deininger and Binswanger 2001, Sunderlin 2007, Larson et al. 2010). Failure to address issues related to rights is likely to lead to elite capture of land and forests and to continued and deeper poverty. A group of more than 100 civil society and indigenous peoples' groups from 38 countries argued that a critical condition for the success of REDD+ is secured and equitable commercial rights to land and resources by forest peoples (Accra Caucus 2010). Such rights are likely to prevent elite capture and to engage communities in REDD+. 
Unclear title can facilitate land grabs. On the other hand, it can also have detrimental effects on REDD+ by creating conflicts, increasing transaction costs or undermining projects. Failure to address rights and tenure issues is likely to lead to elite capture of land and forests. Land grabs and increased deforestation are likely in the period before rights are clarified and regulatory loopholes closed.

\subsection{Limiting forest conversion: The moratorium}

In May 2010, Indonesia's President announced that the government would introduce a 2-year moratorium on conversion of forests as a means of promoting a more sustainable development path and reversing the deforestation trend. In the short term, the moratorium may have significant consequences for major sectors and powerful interests in the Indonesian economy, such as the oil palm, mining and timber industries. Depending on its scope and duration and the ability of the government to enforce it and use the interim period to introduce long-term reforms, the moratorium may support a shift to lowcarbon development, by providing time to introduce long-term policies that shift land use patterns.

After the announcement, several versions of the moratorium plans were circulating, reflecting ongoing efforts amongst interest groups to reach a compromise. The drafts have been prepared by the MoF, UPK4 and the Coordinating Ministry for Economic Affairs. The main differences amongst them concern which forests the moratorium should cover (Carbon Positive 2010, ICTSD 2011, Jakarta Post 2011a).

In May 2011, the President signed Presidential Instruction No. 10/2011, which issued general instructions to the Minister of Forestry, Minister of Home Affairs, Minister of Environment, head of UKP4, head of the National Land Agency, head of the National Spatial Planning Agency, Head of the REDD+ Task Force, governors and ministers. The instruction directs the recipients to take necessary steps in accordance with the tasks, functions and authorities of each agency to support the moratorium on the issuance of new permits on primary natural forests and peatland on conservation, protection, production forests and area for other uses (areal penggunaan lain; APL) as stipulated in the Indicative
Moratorium Map. Also listed were 4 exceptions to the instruction:

1. applications that have received in-principle approval from the Minister of Forestry

2. implementation of vital national development sectors, including geothermal, oil and gas, electricity and land for rice and sugarcane

3. extension of existing forest concessions as long as their permits are still valid

4. ecosystem restoration.

The President also made specific instructions to each of the agencies mentioned above. In particular, he instructed the Minister of Forestry to apply a moratorium on new licences on primary natural forests and peatland in all types of forests and area for other uses based on the Indicative Moratorium Map, to improve the governance on borrow-and-use permits (for the mining sector) and forest concession permits, to improve effectiveness of the management of degraded land, taking into account policies on good peatland management (amongst others, through ecosystem restoration), to revise the Indicative Moratorium Map every 6 months and to determine the final Indicative Moratorium Map after revisions.

However, the Minister of Agriculture and Minister of Energy and Mineral Resources - the sectors known to be the main contributors to deforestation - were not recipients of the instruction.

In the lead-up to the Presidential Instruction, the media reported contradictory actions that might support or undermine the then future moratorium. In January 2011, the MoF ordered logging companies whose permits were issued in 2010 to stop harvesting in primary forests (Jakarta Globe 2011). The MoF also proposed the merger of all state-owned timber plantation companies (BUMN), partly to support a Rp 5.6 trillion government plantation programme (AgroIndonesia 2010a). Two options were under discussion: for the companies to be merged into a new company, or for one of the companies to become the holding company and the others its subsidiaries (Kontan 2010). According to an interview with an MoF official, the second option is more likely; the Ministry of State-Owned Enterprises will set up a restructuring team to follow up on the proposed merger (MoF official, interview May 2011). The MoF has assigned 5 forestry 
BUMNs to rehabilitate conservation and protected forest to make MRV easier (AgroIndonesia 2010b).

However, press reports at the end of October 2010 suggested that the MoF had signed off on the borrow-and-use of forest area (pinjam pakai kawasan hutan) to mining companies for exploration activities to take place in about 1.5 million ha, many in protected areas, contending that underground exploration does not affect forests (Bisnis Indonesia 2010a, Jakarta Globe 2010c). The MoF also promised the South Sumatra government it would allow the rezoning of 600 ha of protected forest in Pantai Air Telang, Banyuasin District, into a production forest (Kompas 2010c). There have been reports that in early 2011, business interest groups petitioned the MoF to announce some 500000 ha of concessions for 2011 in 'degraded forest areas'. More concessions were announced in the first quarter of 2011 than in all of 2010 (ICTSD 2011).

The MoF also issued 2 ministerial regulations that grant special privileges to mining companies with borrow-and-use of forest area and timber use permits (ijin pemanfaatan kayu; IPK). Specifically, Ministerial Regulation P.14/Menhut-II/2011, issued on 14 March 2011, on timber use permits stipulates that mining companies with borrow-and-use permits can harvest and use the timber through an IPK permit. This would allow mining companies to extract timber, and thus obtain profits in addition to revenues from minerals. Ministerial Regulation P.18/Menhut-II/2011, issued on 31 March 2011, on borrow and use of forest areas, stipulates that mining is one of several activities that fall into the category of 'unavoidable strategic objectives' (tujuan strategis yang tidak dapat dielakkan) (Art. 4(2b)). The Indonesian Association of Forest Concession Holders (Asosiasi Pengusaha Hutan Indonesia; APHI) raised concerns about these regulations. Their concerns are related to the stipulation that mining companies that operate within a forest concession are not obliged to coordinate their activities with the forest concessions, and that the timber obtained from land-clearing activities belongs to mining companies rather than to the forest concessions (AgroIndonesia 2011).

These and other decisions are likely to limit the scope of the moratorium or undermine the GoI's ability to enforce it. Indonesia has previously attempted to introduce moratoria on logging. The first moratorium was proposed by then President Megawati in 2002 (Jakarta Post 2002). It never became law, however; as nothing more than a call for reducing the annual allowable cut of primary forests, it was known as a 'soft landing policy' (Barr et al. 2006, Republika 2009). Between 2001 and 2004, the national annual allowable cut was reduced from 11.4 million $\mathrm{m}^{3}$ to 5.7 million $\mathrm{m}^{3}$. Another attempt at a moratorium took place in 2007, when the governor of Aceh introduced a logging moratorium in the province with mixed results (Governor Instruction No. 5/2007; Tempo 2007, Waspada Online 2007, World Bank 2008, Medan Bisnis Daily 2009). These and other experiences and the 2-year timeframe of the current moratorium raise questions about its potential effectiveness to limit largescale forest conversions in the long term.

\subsection{Risk of corruption in REDD+ policymaking}

The risks of corruption occurring in REDD+ policymaking in Indonesia are significant because conditions in the policymaking process facilitate corrupt practices. Both interim measures such as the moratorium and longer-term reforms will limit expansion into forests and threaten those who benefit from the status quo and who are politically strong (Fernandez and Rodrik 1991). Indonesia's forestrelated wealth, although declining, is still vast, and planned or draft policy decisions will affect powerful vested interests. Resistance, opposition, pressure and corruption, therefore, can be expected from those who see the reforms and measures as a threat.

Restrictions on forest conversion have implications for the mining, oil palm and pulp and paper industries, amongst others. The oil palm and mining industries reacted swiftly to the announcement of the moratorium, calling a series of meetings (BMI 2010, Info Sawit 2010, 2011a, Jakarta Globe 2010b). Their main view, which seems to be shared by the MoF, is that a moratorium on both primary and secondary forests would hinder industrial expansion and harm Indonesia’s economic development (ICTSD 2011; Info Sawit 2011b). World Growth, an organisation closely associated with and funded by Malaysian palm oil and timber businesses, directly accused the President of making costly commitments and called for the moratorium to be put aside (Jakarta Post 
2010e). More direct - or indirect - opposition and influence can be expected from these and other sectors traditionally connected with political elites in forestry.

Other conditions that facilitate corruption in the policymaking process include a lack of - or at least limited - transparency. During the past few decades, citizens all over the world have consistently demonstrated their unwillingness to tolerate secretive, closed-door decision-making. They insist that governments should disclose more information on many grounds, 3 of which are especially relevant to policy decisions regarding REDD+. First, demands for open and transparent government often accompany any attempt to crack down on corruption. Especially in resource-rich countries, transparency is increasingly viewed as central to curbing corruption and other dysfunctions. The proponents of greater disclosure also argue that transparency is critical in achieving public policy effectiveness and efficiency. Apart from the practical considerations, transparent decisionmaking is critical for informed consent, the essence of representative democracy (Florini 2007, Kolstad and Wiig 2009). Indonesia adopted Law No. 14/2008 on access to information in April 2008, which secures the public's right to public information generated, stored and managed by executive, legislative and judicial bodies. However, many strategic decisions on REDD+ are being made without sufficient transparency or inclusion. For example, the MoF's submission of the R-PP to the FCPF in May 2009 was followed by criticism from civil society for insufficient consultation and transparency (Down to Earth 2009). The GoI has also been criticised for not informing or consulting small-scale farmers, indigenous people and broader civil society prior to making international commitments such as the deal with Norway. The GoI has been warned that such international deals, made without consultation with affected or interested groups, or release of relevant information to them, may 'turn into unworkable activities on the ground due to complex conflicts and tension' (Jakarta Post 2010c).

However, simply making information available will not prevent corruption if other aspects of a society, such as education and the media, are weak. Increasing transparency must be accompanied by measures to strengthen citizens' capacity to act upon the available information - only then can transparency really help to combat corruption. Further, transparency reform should focus on the areas with the greatest impact on reducing the risks of corruption associated with natural resource wealth (Fung et al. 2003, Florini 2007, Kolstad and Wiig 2009, Lindstedt and Naurin 2010).

Policy confusion, inconsistency and gaps, competing objectives and interests, missing or inaccurate data and information, unclear titles to areas of land and other conditions are all major loopholes that allow discretionary decision-making and corruption by vested interests. These create a governance environment that is easy for those interests to manipulate for their own protection. The GoI is taking steps to address governance weaknesses; however, various reports and contradictory developments cast doubt on their success. NGOs have warned that the Norway-Indonesia REDD+ partnership could potentially fail because timber and oil palm companies might try to undermine the moratorium (Greenpeace 2010, Jiwan 2010). Oil palm companies have voiced concerns that the LoI would reduce oil palm expansion from an average 350000 ha to 200000 ha annually (Slette and Wiyono 2011). However, some companies do not appear to be affected by the moratorium, particularly large oil palm companies that have not fully planted their land banks. For example, Gozco Plantations has 124000 ha of land banks, of which only 35000 ha has been planted. Another large company, Wilmar International, has more than 570000 ha of land banks, of which only about 235000 ha has been planted (Widhiyanto 2011).

In addition to the risk of corruption enabled by general governance weaknesses and gaps in the forestry sector, some specific risks are associated with the emerging REDD+ architecture. REDD+ is concerned with sustainable forest land use and reductions of emissions in the forestry sector, and the objective of sustainable development is defined in GoI strategy documents. However, REDD+ does not necessarily guarantee sustainable development, forest conservation or reforestation. REDD+ may or may not support sustainable development depending on its rules and structure. In this way, REDD+ can learn from and avoid the mistakes and structural weaknesses that emerged in other efforts under the UNFCCC such as the CDM. 
One of the CDM's 2 main goals is to promote sustainable development in developing countries (UNFCCC 1998). Its initial aim was to do so by spurring low-carbon energy infrastructure in developing countries. However, by providing perverse incentives and allowing manipulation, the CDM has failed in this regard. Until 2006 at least, the supply of certified emission reductions (CERs) in the CDM market was dominated by large projects in relatively obscure chemical industries. The situation has changed somewhat since then with an increased share of renewable energy, but the biggest share of CERs continues to be generated for reductions of non- $\mathrm{CO}_{2}$ GHGs in the chemical industry (Wara 2006, International Rivers 2008). Thus, the CDM has failed to support a shift to a low-carbon energy path in developing countries and to contribute to host countries' sustainable development, or any contribution it has made is relatively small (Wara 2006, Schneider 2007).

The CDM experience further indicated that manipulation of baselines and increases in emissions can occur. During the establishment of baselines, data can be manipulated and emissions can be over-reported or even actually increased. Project proponents might increase emissions prior to the establishment of baselines so that they can show higher emissions ex ante and thus claim more reductions ex post (Brown 2010). One of the reasons CDM projects were concentrated in the chemical industry in 2005-2007 was the opportunity to manipulate baselines and increase emissions before a project started. Other incentives to invest primarily in projects reducing HFC-23 and adipic/nitric N20 acid during that period included the price spike in 2005, when the price of CERs climbed to its peak of more than 20 euros per $\mathrm{CO}_{2} / \mathrm{t}$ and the fact that the revenues from CERs may be considerably higher than the market price for HCFC-22 and thus also higher than production costs (Wara 2006, Schneider 2007, European Energy Exchange, www.eex.com). Chemical plants took advantage of the CDM's structural flaws to increase production HFC-23 - a GHG - so they could then destroy it and be eligible to sell emission reductions through the CDM. HCF-23, however, is a by-product of HCFC-22 - another GHG. To increase HFC-23 production and removal, industries had to increase HCFC-22 production. Thus, they increased the global GHG emissions, in addition to manipulating baselines. In REDD+, inaccurate land classification and absence of data on permits and boundaries may allow illegal or unlawful deforestation and manipulation of baselines. It could lead to grabbing land that is attractive for deforestation now and easy credits, or to the establishment of REDD+ projects that do not necessarily support sustainable development objectives.

In sum, the main risks for REDD+ in the policymaking process are increased deforestation and manipulation of baselines, unsustainable land use practices and encroachment on forest communities and their lands and rights. Corruption and manipulation of the policymaking process may prevent a shift in development paths and undermine REDD+ in its goals of reducing deforestation and forest degradation. 


\section{Improving coordination}

The REDD+ readiness phase in Indonesia already involves large and growing amounts of public, primarily donor, funds and private investment. Successful use of these funds for policy reform and a shift to low-carbon development will require cooperation amongst agencies (Verchot et al. 2010). The LoI between Indonesia and Norway states that ensuring coordination with all other REDD+ initiatives is one of the general approaches and principles in the cooperation between two countries (LoI 2010).

Poor or non-existent coordination creates immediate risks of misuse of donor funding as well as the risk that individual agencies will adopt policies that favour specific interests. In the latter case, it is likely to constitute grand corruption, whilst in the former it may be petty corruption, depending on the scale of the funds misused.

\subsection{Coordinating agencies and efforts}

Since 2007, the GoI has set up several new mechanisms to coordinate the REDD+ policy development, amongst them the Indonesia Forest Climate Alliance (IFCA), the National Climate Change Council (Dewan Nasional Perubahan Iklim; DNPI), the REDD+ Working Groups and the REDD+ Task Force (see Table 1). The REDD+ Task Force/UKP4 under the President is currently taking the lead in coordinating measures and policies for the implementation of the LoI with Norway.

Many agencies and stakeholders are involved in these coordinating mechanisms. Bappenas has led the development of the Nastra and made significant investment in consultations with stakeholders. Other agencies outside the forestry sector have carried out activities that may have relevance for REDD+. For example, the KPK and the BPK are playing important roles in reviews and audits of the forestry sector and in identifying necessary measures to curb corruption.

It is evident, then, that efforts to improve coordination are underway. However, such efforts are hampered by several weaknesses and possible bottlenecks. Whereas some agencies have a stake in the outcome of the process, others may be motivated only by the prospect of funding. Some major sectors that have encouraged deforestation and forest degradation, such as mining and agriculture, are still not formally represented in any of the mechanisms designed to coordinate cross-agency efforts. The involvement of the financial sector is critical for the transparent management of large funds for REDD+ readiness and transfers and payments during implementation. Furthermore, Bank Indonesia is not involved - or even considered - in any of the coordinating mechanisms.

Indonesia has been criticised for concentrating 'ownership' of REDD+ in the MoF, as this creates the possibility that conflicting forest legislation, such as in relation to plantations and peatlands, will continue to drive deforestation (Down to Earth 2009). Despite improvements to coordination, the involvement of more agencies in the REDD+ policymaking process has led to multiple proposals, drafts, plans and other measures. In some instances, measures and plans go beyond the mandates of the proposing agency, which potentially undermines their implementation.

Some of the coordinating mechanisms are led by a line ministry - the MoF - and others are under the President's office. Bappenas led the development of the Nastra, but the MoF created the draft readiness plan, and the 2 documents partially overlap.

Further, the presence of numerous coordinating mechanisms creates confusion. According to a member of the Indonesian delegation to COP 16, it is unclear which agency is leading international negotiations the REDD+ Working Group, the MoF or the DNPI (Jakarta Post 2010d). The Ministry of Foreign Affairs also has a role to play in international negotiations and deals, such as the arrangement with Norway, which introduces further confusion about leadership. 


\subsection{Risks for REDD+ related to coordination}

An aspect likely to obstruct or at least hamper coordination is the existence of established areas of authority and mandates by the various agencies and their desire to protect them. Turf battles may lead to stalemates and undermine policy efforts, as indicated by the disagreement and the stalemate between the MoF and the Ministry of Finance over which department should be making decisions on the distribution of REDD+ revenues.

Conflict and competition between central agencies and regional governments have also emerged. The participation of Aceh, Papua and the increasing number of provinces joining the Governor's Climate and Forest Task Force (GCF) has sparked opposition from central government officials who feel they have been bypassed. Tensions between central and subnational levels of government are increasingly apparent in relation to issuing permits and concessions, where each level of government seeks to protect its territory (MoF official, interview 2011, Jakarta Post 2011a). ${ }^{2}$
Indonesia is not unusual in this regard - agencies throughout the world protect their mandates - but such turf battles create a barrier to the cross-agency and cross-sectoral cooperation needed for REDD+, as does the omission of critical sectors from the coordinating mechanisms. Turf battles and failure to involve all stakeholders undermine governmental effectiveness and create opportunities and entry points for corruption.

The lack of clarity of roles and the confusion regarding leadership may open entry points for vested interests to exert their influence. Furthermore, it is unclear how the shift in ownership and the creation of new institutions will influence the ability to make decisions and pass legislation. Overhauling long-standing governance conditions, institutional culture and individual networks is a daunting task. Competing mandates, turf battles, confusing roles and efforts to build new institutions make this task even more difficult.
2 The 1999 Forestry Law stipulates that forest use permits should be issued by the MoF in Jakarta. Regional autonomy laws, however, allow local administrations to issue permits for small-scale companies, but they still need to obtain approval or be verified by the MoF or its technical implementing units in the region. 


\section{Climate finance}

The main idea behind REDD+ is that developed countries can offset their emissions by paying developing countries and project developers for reducing emissions from deforestation and forest degradation. A wide array of arrangements is emerging to manage donor pledges (WRI 2010) or developing countries' own forest- and climate-related funding allocations.

One of the main questions in both international and national discussions on REDD+ finance today is how the finance can be effectively delivered to and within countries. The main concerns are that REDD+ finance will not be coordinated, not owned by the respective national governments and not aligned with national governments' systems (Brown and Peskett 2011). Other concerns are that REDD+ finance will focus exclusively on the design, implementation and monitoring of REDD+ without paying attention to such underlying conditions for success as tenure security, the presence of institutions in forest areas to absorb carbon payments and governance reform to combat corruption (Macqueen 2010).

In Indonesia, REDD+ funding mechanisms are evolving to support the readiness phase in terms of policy and institutional development as well as onthe-ground investment in REDD+ demonstration projects. With significant donor support already pledged to Indonesia, it is important to understand the potential bottlenecks and risks of misuse and corruption and learn from experience in forest finance or from more recent efforts in climate finance. Currently, grand corruption may shape the way in which financing mechanisms work and ensure that special interests have access to REDD+ finance. It may also create loopholes, which may later allow for both grand and petty corruption, when the mechanism is tied to a carbon market and performance in reducing emissions.

\subsection{Climate finance in Indonesia}

Indonesia is one of the first countries to be building institutions to manage and distribute climate finance.
Much of this finance is associated with donor funding or soft loans. Climate funds in Indonesia include the Climate Change Program Loan (CCPL), the Indonesia Climate Change Trust Fund (ICCTF) and the Indonesia Green Investment Fund (IGIF), as well as direct project and programme support. Of these, the CCPL, ICCTF and IGIF, which operate at national level, coordinate, or aim to coordinate, financing from various sources.

The CCPL is managed by the Ministry of Finance and is part of the general budget allocations. The CCPL is a concessional loan financed by Japan (Japan International Cooperation Agency; JICA) and France (Agence Française de Développement; AFD) since 2008, with the World Bank joining in 2010, to support the GoI's efforts to develop a lower-carbon, more climate-resilient growth path. It allows the GoI to reduce the fiscal deficits of the agencies (recipients of the loan) and presumably creates incentives to adhere to climate policies already planned. A Steering Committee and Joint Monitoring Meeting review respective agencies'/loan recipients' progress in implementing policies (Brown and Peskett 2011). In this way, the CCPL supplements regular agency budgets; it is unclear how and to what extent it directly supports emission reductions in forestry.

The aim of the ICCTF is 'to contribute effectively and efficiently to mainstreaming climate change issues in government planning and the implementation of climate change activities across Indonesia. The ICCTF was created by Bappenas as a national managed trust fund with 3 funding windows: energy; forestry and peatlands; and adaptation and resilience. Its objectives are to increase the Gol's effectiveness in achieving Indonesia's goals of a low-carbon economy and better resilience and adaptation to climate change. In September 2009, the UN Development Programme (UNDP) was appointed to administer the ICCTF on an interim basis. ICCTF management includes a Steering Committee composed of donors and development partners, a technical committee and a secretariat. A GoI Ministerial Steering Committee provides policy 
guidance. Three donors currently contribute to it: UKaid, AusAID and Norway (see www.icctf.org and http://www.undp.or.id). This may represent an early step in improving coordination of donor climate funds to Indonesia, although most of the donors already involved do not channel their funds through the ICCTF.

The plan to establish the IGIF, a new national climate fund, was announced by President Yudhoyono in Copenhagen in 2009. The IGIF aims to catalyse infrastructure development that could speed up economic growth, boost food and clean water production and help cut GHG emissions. Indonesia's Government Investment Unit has allocated US $\$ 400$ million into the fund, with a further US\$900 million expected from donor governments and institutional investors (Jakarta Globe 2010a; Brown and Peskett 2011). The AFD, UKaid, JICA, Korea and the Islamic Development Bank have expressed an interest in contributing to the fund but the amounts are not yet clear. IGIF financing will comprise a blend of grants, concessional loans and equity to develop low-carbon business models at scale, primarily in energy and sustainable land use. The idea is to blend private and public - and national and international - financial resources for climate mitigation. IGIF is not a fund per se but an association of individual accounts managed by contributors using different rules but at the same intermediary bank (Brown and Peskett 2011).

\subsection{Experience with management and distribution of forest funds in Indonesia}

The potential effectiveness of public funding for climate change mitigation in Indonesia is likely to be influenced by the ability of existing and new institutions to address a number of challenges, one of which is the prevention of corruption or mismanagement of REDD+ funds. Past experience with forest finance and forest funds can provide lessons for REDD+ finance in Indonesia.

The current forest revenue distribution system is regulated by Law No. 33/2004 on revenue sharing between the central government and the regions, and its implementing regulations stipulate that revenues be shared across levels of government. The share received by each level of government differs according to the revenue source, as does their eligibility. Approval and disbursement involves the MoF, the Ministry of Finance and, in some cases, the Ministry of Home Affairs (Figure 1).

Any mechanism for the distribution of REDD+ revenues is likely to be different because it will distribute revenues amongst government departments, developers and communities, not just amongst different levels of government.

Decisions on who will receive and manage revenues have not yet been made, and it is unclear how a future system would operate. However, a REDD+ payment mechanism may have similarities with the current forest revenue distribution system because it will need to work across scales, distribute different shares of the revenue amongst entities, establish eligibility criteria and define approval and disbursement processes.

The disbursement and management of revenues across scales present several challenges. One is delays in disbursement and spending - a frequent problem in the distribution of large funds when financial management capacity is poor (Subarudi and Dwiprabowo 2007). Delays in disbursement in turn cause delays in implementation of subnational governments' development programmes. To avoid delays, provincial and district governments either directly lobby the MoF and Ministry of Finance, or indirectly lobby the national members of parliament who represent their respective regions (Resosudarmo et al. 2006). The approval and allocation process also involves a lot of back and forth amongst districts, provinces and central agencies, which causes further delays.

Revenues from the Forest Concession Fee (IHPH) and Forest Resource Rent Provision (PSDH) are transferred into an MoF bank account; from this account, revenues are further distributed to local level. At province and district levels, the funds are integrated into the provincial and district budgets, which means that the revenues may or may not be used for forest-related activities. In many cases, the shared forestry revenues are insufficient to cover the budget of provincial or district forestry offices (Dermawan 2004). 


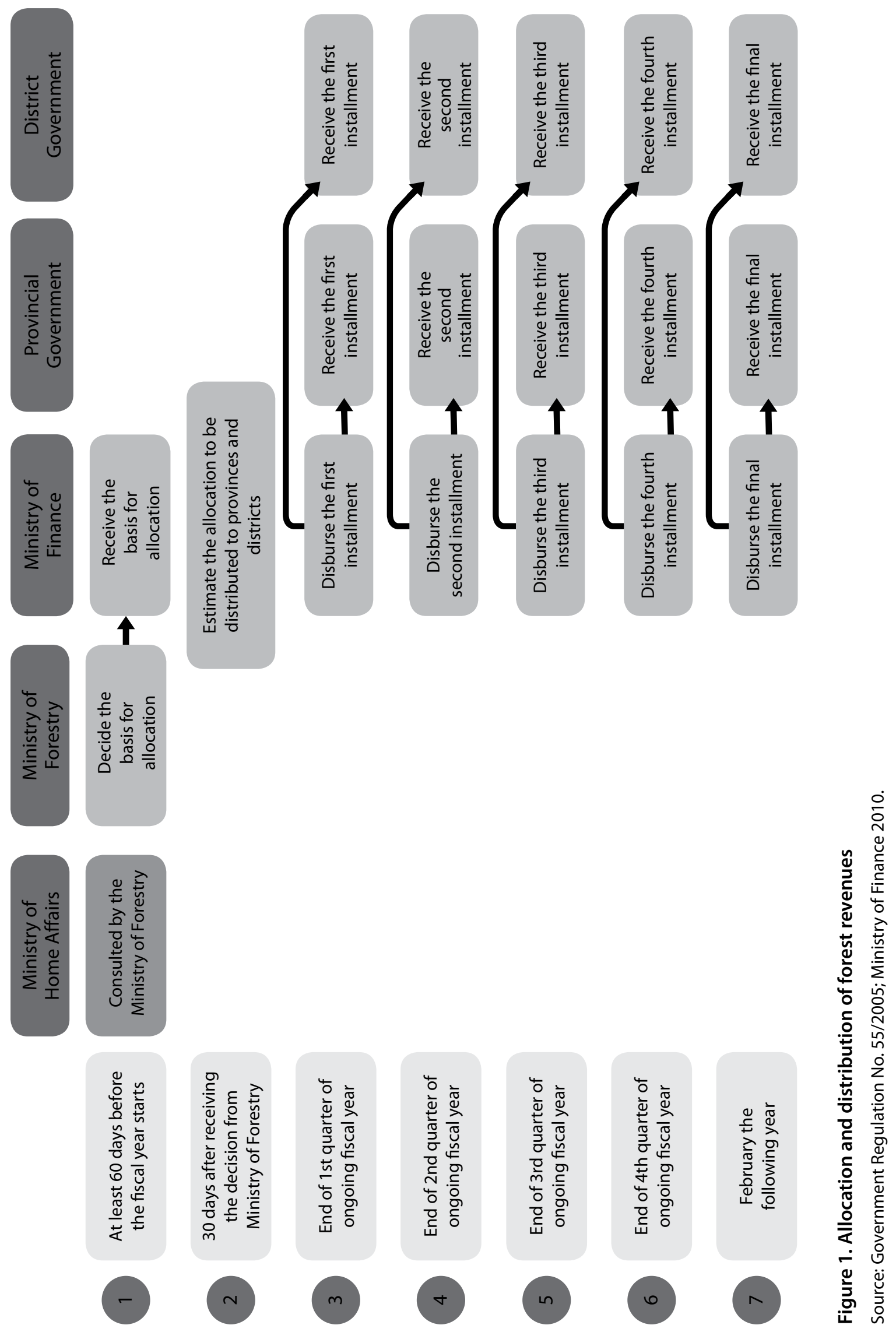


However, perhaps the most important challenge is how the government uses the revenues. Media reports and BPK audits for some provinces that were recipients of the DR indicate that, even though some DR funds were earmarked for certain projects, they were frequently diverted to ineligible activities or to non-existent projects. Although the DR was intended to promote reforestation and forest rehabilitation, it was used by the Soeharto regime to finance politically favoured projects and allowed politically connected or family networks to capture large transfer rents. The transfer of the DR to the Ministry of Finance and its integration into the state budget in 1998-1999 introduced important checks and balances but some weaknesses remained, such as disbursement problems, inability to manage funds effectively (especially by provincial and district governments), weak internal controls and poor reporting (Barr et al. 2010). Two agencies - the BPK and the KPK - have played significant roles in improving the transparency and accountability of the DR fund and reducing risks of corruption. The BPK has identified weaknesses and steps for improvement in its numerous audits of the DR. The KPK has successfully prosecuted high-profile DR corruption cases (Barr et al. 2010). However, poor financial management, accountability, transparency and capacity persist, and many of the officials and the powerful politically connected groups that directly benefited have gone unpunished (BPK 2008).

\subsection{The role of banks in the Reforestation Fund}

The relationship between the MoF and the intermediary banks may partly explain the DR's poor performance in achieving its stated objectives and offer a lesson for REDD+. One reason banks failed to support the appropriate use of the DR was the contradictory, unclear lines of authority. A 2008 audit report noted that the banks had generally failed to enforce conditions on defaulted loans from the DR (BPK 2008). The MoF expected the banks to enforce the conditions of the loans, but the banks maintained that they could do so only after authorisation by the MoF. Another reason for the banks' failure may have been the lack of incentives to call in the loans and enforce contracts; in fact, they had incentives not to. They received a percentage of the money disbursed from the DR, but paid-off debts reduced this percentage. Therefore, they had financial incentives to disburse

\section{Box 3. The Reforestation Fund}

The introduction of the Reforestation Fund (Dana Reboisasi; DR) and subsequent increases in the fee rate, triggered a substantial increase in the state's capture of timber rents. During the final decade of the Soeharto era, the government of Indonesia collected approximately US\$2.6 billion in nominal receipts to the Reforestation Fund, whilst interest accrued on the principal amounted to an additional US\$1 billion. On an annual basis, DR receipts and interest during the last 5 fiscal years of the New Order period ranged from US\$395 million in 1997/8 to US\$540 million in 1995/6.

During the Soeharto era, the Ministry of Forestry used the DR to promote the development of industrial timber and pulpwood plantations, allocating more than US\$1 billion in cash grants and discounted loans to commercial plantation companies. The ministry distributed a substantial portion of the DR funds and forest conversion licences to companies with close ties to state elites, allowing a few well-connected actors to capture sizeable forest rents. Ten companies, all directly connected to the Soeharto regime by either family or political ties, received US\$635 million, or about two-thirds of the DR funds allocated for timber plantation development. In addition, the ministry disbursed US\$600 million to finance politically favoured projects that had little to do with the DR's mandate of promoting reforestation and forest rehabilitation.

DR subsidies for developing plantations encouraged overharvesting of logging concessions and clearing of 'degraded' natural forests. Timber companies had a strong incentive to mismanage the forests in their concession sites so that they would be eligible for subsidies to convert these areas to timber or pulpwood plantations. The current administration is using DR funds to promote the development of 9 million ha of new plantations by 2016 to 'revitalise' the nation's commercial forestry sector. 
the funds but not to call in the loans or enforce them (Barr et al. 2010).

Selecting an appropriate intermediary bank is an important step in ensuring efficiency in management of funds. A 2008 analysis showed that the Indonesian banks most efficient in managing funds were the large 'state-owned' banks, and the least efficient were 'regional government-owned' banks (Hadad et al. 2008). However, as the DR example shows, even large, efficient Indonesian banks cannot enforce contracts or prevent misuse if their relationship with the government is not adequately structured.

\subsection{Learning from finance in forestry, climate and the environment}

Of the numerous initiatives aiming to protect tropical forests in the context of climate change, 16 are funds that manage or have been pledged more than or close to US\$50 million (Macqueen 2010). Of these, 7 major bilateral and multilateral funding initiatives have been created explicitly to fund REDD+ (Caravani et al. 2010). Most of the large, donor-pledged, multilateral REDD+ funds are managed by the World Bank or other regional development banks, the Global Environment Facility or UN agencies such as the UNDP and FAO (Food and Agriculture Organization). Other funds, such as the Global Climate Change Alliance (GCCA) or the Hatoyama Initiative (HI), are managed by the respective developed-country governments. Only 1 country-level climate fund operates outside of Indonesia - the Amazon Fund (FA), which is administered by the Brazilian Development Bank (BNDES) and involves the Amazon Fund Guidance Committee (COFA), a 3-block committee composed of state government, federal government and civil society representatives (Macqueen 2010).

The number of REDD+ funds is growing rapidly. Most have been established since 2007; they tend to be forestry sector-driven, government channelled, often controlled by a governmental or intergovernmental organisation (such as the UNDP) and self-monitored. Their approach is to reduce transaction costs and to compensate financial opportunity costs for keeping the forests standing (Macqueen 2010). Many of the existing funds coordinate the support from donors. In many ways, however, they fail to or only partly address other important concerns - ownership by recipient governments or tenure security, building institutions in forest areas to absorb carbon payments and reforming governance to combat corruption (Macqueen 2010, Brown and Peskett 2011).

Other past initiatives that may provide useful lessons for REDD+ are debt-for-nature swaps. Similarly to how REDD+ is currently developing in Indonesia, debt-for-nature swaps are bilateral arrangements between developed and developing countries. In the 1990s, debt-for-nature swaps were considered a new strategy to control the exploitation of natural resources, including forests, without ignoring the economic needs of developing nations. By 2000, more than US $\$ 1.5$ billion in transactions had been exchanged in debt-for-nature or debt-forenvironment swaps amongst more than 19 countries (Thapa 2000).

Even though debt-for-nature swaps are fundamentally different from a REDD+ scheme - as the former are linked to growing debt in developing countries - the 2 mechanisms do have similarities and shared objectives. Very much like REDD+, debtfor-nature swaps aim to reduce the exploitation of natural resources - forests in the case of REDD+. As in REDD+, several actors are involved in each debt-for-nature swap - the government of the indebted country, a donor (government or private), a bank and, in many cases, an international and a national NGO.

Debt-for-nature swaps provide several relevant lessons for REDD+. With few exceptions, most swaps occurred in forest- and biodiversity-rich developing countries, characterised by weak enforcement of legal claims to environmental resources, high costs for delineating and monitoring environmental outcomes and nominal government ownership of the resources involved (Deacon and Murphy 1997). Their success required local involvement and support by communities, as well as programmes to build local capacity to implement projects as part of the financing under the swaps. Swap projects also demonstrated the difficulty and costs associated with monitoring outcomes. 


\subsection{Risks related to REDD+ finance}

As current experience with climate finance in Indonesia and globally indicates, efforts are being made to address issues related to donor coordination. However, experience with forest, environment and climate finance and debt-for-nature swaps, as well as emerging climate finance schemes in Indonesia, indicates several outstanding issues also.

Most emerging or existing climate finance arrangements fail to fully address concerns about ownership by a recipient country and alignment with national governance systems. There seems to be little understanding of the financing needs for effective climate change mitigation actions (Brown and Peskett 2011). The high costs of monitoring environmental outcomes and weak enforcement and ownership arrangements, as demonstrated by debt-for-nature swaps, require up-front investment in governance beyond the preparation for REDD+. However, currently no or little attention is being paid to address issues related to the clarification of state and community forest boundaries and to building the capacity of subnational forest-related institutions. Failure to attend to these issues could threaten the effectiveness of REDD+ donor funding as well as the equity and effectiveness of REDD+ in the future. Further, most existing funds are self-monitored and do not have built-in plans for independent audits or oversight. Given past experience in Indonesia, the absence of independent financial monitoring and investment in capacity for financial management clearly heightens the risk that REDD+ funds will be misused.
These various weaknesses create risks of corruption and mismanagement of climate finance in several ways. Past problems with the effectiveness of donor financing may be replicated. The underlying causes of mismanagement, such as capacity of government and local institutions, may not be adequately addressed. Well-connected international and national networks may receive the greatest benefits. Or the climate finance may have no effect on reducing carbon emissions from forests because the funds are used for purposes other than that for which they were intended.

As international and Indonesian experience indicates, several steps can be taken to reduce these risks and address current weaknesses. National institutions entrusted with fighting corruption and money laundering such as the KPK, PPATK and BPK should be involved in creating checks and balances and ensuring financial and other monitoring of climate funds as well as of the people and organisations associated with or benefiting from them. Attention should also be paid to processes to ensure all agencies involved in managing and disbursing funds or in enforcing conditions are held accountable. Independent oversight and public information disclosure are likely to mitigate the risks of corruption in REDD+ finance. The capacity of the national government and especially of local institutions should be boosted so that they can effectively and appropriately manage, account for, disburse in a timely manner and/or use REDD+ funds. The government's relationship with intermediary banks should be structured to avoid mismanagement. In addition, as debt-for-nature swaps and many existing climate finance arrangements suggest, local ownership is also critical for success. 


\section{REDD+ benefit sharing}

An important - and in the long run critical element of a REDD+ regime will be the distribution of benefits across scales and amongst participants. Several factors determine the importance of a revenue distribution mechanism. REDD+ is intended to be performance-based, which implies that payments are contingent on performance or on the amount of additional, real and measurable reductions in carbon emissions from deforestation and forest degradation. A distortion of the contingency of the payments for performance in terms of emission reductions or structural flaws that fail to ensure additionality or real emission reductions would lead to underperformance or even malfeasance, perverse incentives and general failure of the mechanism. Second, to function as an incentive for a pro-poor, pro-environment, lowcarbon development path, REDD+ must create jobs and incomes. If it fails to do so, it will face on-theground opposition. It will also be unable to compete with conventional development. Finally, as some authors assert and examples from other countries suggest, REDD+ is unlikely to succeed if forestdependent communities and indigenous peoples do not benefit from it and support it (Cronkleton et al. 2011, Reed 2011).

Therefore, it is important to identify any bottlenecks in the emerging plans for distribution of REDD+ benefits and to determine whether the plans are likely to provide incentives for additional REDD+ projects or contribute to sharing benefits with the communities and people living in the forests.

As the benefit-sharing mechanism is yet to be discussed and developed, the main current risks are that grand corruption will occur, with the objective of shaping the mechanism in order to later receive a share of REDD+ payments without performing or ensuring additional and real emission reductions. A benefit-sharing mechanism will also provide incentives - or not - for investment in REDD+ and determine where such investment goes - towards preserving high carbon value forests and peatlands or towards other activities. Depending on how it is shaped, such a mechanism may even provide incentives to increase deforestation at particular points in the evolution of REDD + to the benefit of special interests.

\subsection{Distribution of REDD+ revenue and benefits}

The Nastra and other REDD+ strategies acknowledge the need to make decisions on benefit sharing but do not provide specific guidance on how benefits will be shared (GoI 2010). Discourses in the media suggest that equity issues and benefit sharing are not a priority for the national government. They also suggest that the perspectives and positions of the various actors in the national debate and of governments at all scales differ significantly (Cronin and Santoso 2010).

MoF has issued a regulation on sharing anticipated benefits from REDD+ under a voluntary carbon market mechanism (Ministerial Decree P.36/MenhutII/2009). The Ministry of Finance has challenged the regulation, but no revision had taken place at the time of writing this report. The regulation sets out the shares of revenues for the government, developers and communities (Table 2). The distribution differs for each type of REDD+ project and is subject to change, depending on the resolution reached between the MoF and the Ministry of Finance.

The distribution amongst actors may change if a new regulation is ultimately approved. However, as the table indicates, the current proposal for revenue distribution introduces a complex system: different types of permits involve different percentages for government, communities and developers.

The most important feature of the proposed revenue distribution relates to the types of REDD+ activities it encourages. Developers have the most incentive to establish REDD+ through the 3 types of concessions - logging, restoration and timber plantations - where they will receive the highest percentage of the revenue. Logging, timber and ecosystem restoration concessions are large-scale 
Table 2. Distribution of REDD+ revenues amongst actors

\begin{tabular}{|c|c|c|c|}
\hline \multirow{2}{*}{ Licence holder or developer } & \multicolumn{3}{|c|}{ Distribution (percentage) } \\
\hline & Government & Communities & Developer \\
\hline IUPHHK-HA (logging concession) & 20 & 20 & 60 \\
\hline IUPHHK-HT (timber plantations) & 20 & 20 & 60 \\
\hline IUPHHK-RE (ecosystem restoration concession) & 20 & 20 & 60 \\
\hline IUPHHK-HTR (community timber plantation) & 20 & 50 & 30 \\
\hline Hutan rakyat (private forest) & 10 & 70 & 20 \\
\hline Hutan kemasyarakatan (community forest) & 20 & 50 & 30 \\
\hline Hutan adat (indigenous forest) & 10 & 70 & 20 \\
\hline Hutan desa (village forest) & 20 & 50 & 30 \\
\hline Kesatuan Pemangkuan Hutan (forest management unit) & 30 & 20 & 50 \\
\hline Kawasan Hutan Dengan Tujuan Khusus (special use forest) & 50 & 20 & 30 \\
\hline Hutan lindung (protection forest) & 50 & 20 & 30 \\
\hline
\end{tabular}

Source: Ministry of Forestry Decree No. 36/2009

plantation projects. Currently, they occupy millions of hectares of forest land (see Table 3). Several initiatives, including subsidies, are already in place to support reforestation efforts. The MoF aims to add 5 million ha to timber plantations by $2016(\mathrm{MoF}$ 2009). The implications - and possible outcomes of the current proposal for distribution of REDD+ revenues are that REDD+ in Indonesia will primarily focus on reforestation. Alternatively, the intention may be to provide sufficient, competitive incentives to the large concessionaires that hold some of the high carbon value, high conservation value forests to encourage them to preserve the forests rather than develop them.

There are several problems with this approach. One is the issue of additionality and the validity of claimed emission reductions. As with the CDM, REDD+ will require that projects are additional and emission reductions are real. The CDM experience suggests that some structural flaws provide incentives to projects without valid additionality or emission reductions. Even though estimates vary, both scientists and activists have provided ample examples of questionable additionality for $33 \%-75 \%$ of all CDM projects registered before 2008 (Schneider 2007, International Rivers 2008, Victor and Wara 2008). It is also questionable whether these projects' emission reductions are real (Nova 2010). In June
2010, in a joint submission to the UNFCCC, NOE21 (Economie, Energie et Société), the German NGO Forum on Environment and Development and CDM Watch stated: 'Analysis of monitoring data from all registered HFC-23 destruction projects revealed that CDM HCFC-22 plants are intentionally operated in a manner to maximize the production of offset credits. The analysis indicates that because of the extra CDM revenue more HCFC22 is produced and far more HFC-23 generated than would occur without the CDM.'

Experience suggests that there may be reason to doubt whether timber plantations in Indonesia can guarantee additionality and real emission reductions. For example, current MoF figures on timber plantation development have been challenged, and there is evidence that only half of the current cumulative estate, reported at 4 million ha, is actually fully planted and productive (Verchot et al. 2010). It is questionable whether plantations that are already planned, subsidised and supported by government programmes, as large-scale timber plantations in Indonesia are, can prove additionality.

Given the poor performance of plantations and reforestation efforts supported by the government, reported emission reductions may not be real either. There have been instances when a national 
agency or a local government awards licences allowing companies to develop plantations in forests where such development is restricted by existing regulations. In most cases, such a decision by a government agency is likely connected to corruption. In a REDD+ regime, the concessionaire can claim REDD+ payments by increasing deforestation prior to establishing a baseline by cutting the trees and can then report emission reductions by planting new trees. For example, Asia Pulp \& Paper is now launching a REDD+-type project for about 15600 ha in a concession in Kampar Peninsula allegedly awarded in violation of the law (Businesswire 2010, Lang 2010c). In such cases, the concessionaire fails to meet 2 critical requirements of a future REDD+ regime additionality and real measurable emission reductions. Rather, its claims can be fraudulent, likely involving corruption. Therefore, timber plantation development within the rubric of REDD+ may replicate the additionality problems demonstrated in the CDM.

The regulation currently under discussion indicates that local communities and indigenous people in Indonesia will benefit most from REDD+ by using permits for community timber plantations, community forests, indigenous forests, village forests and private forests, for which they will receive $50 \%-$ $70 \%$ of the payments. However, developers are not likely to be interested in REDD+ projects established in such forests, because their share is relatively small. For example, communities will obtain $70 \%$ of the payments generated by REDD+ projects in private forests, but developers will receive only $20 \%$. In this way, the proposed regulation creates disincentives for developers to invest in community and indigenous forests, meaning the communities will have to engage in REDD+ directly.

One way to engage small-scale concessionary models in REDD+ would be through markets for environmental services and payment for environmental services (PES) schemes. However, this approach is highly unlikely to eventuate, given past (albeit limited) experience ${ }^{3}$ and the serious barriers to the development of a voluntary market for environmental services, including carbon. Such barriers include (1) the absence of a regulatory

3 In 2004, 81 such projects existed in Indonesia (Suyanto et al. 2005). framework to promote such markets; (2) the small size of holdings; (3) unclear tenure rights, in particular the absence of commercial rights; and (4) absence of data to determine additionality (Suyanto et al. 2005, Huang and Upadhyaya 2007, Accra Caucus 2010, Pirard and Bille 2010). In addition, communities in Indonesia are unlikely to have the capacity to participate in voluntary carbon markets, which seem to support smaller projects, especially projects in forestry (Syngellakis 2011).

Furthermore, small-scale projects and PES-like arrangements for REDD+ in Indonesia are unlikely to be attractive in a compliance market similar to the CDM market, which is dominated by large-scale projects (Wara 2006).

Experience with timber plantations in Indonesia suggests that the current benefit-sharing proposal may replicate some of the structural flaws of the CDM - which provides incentives to large-scale projects with questionable additionality, doubtful emission reductions and unlikely contribution to sustainable development. Even if the REDD+ design and architecture address these structural flaws, future benefit-sharing proposals still need to clarify the role of communities and how they can contribute towards emission reductions in order to receive their share of the benefits. Barriers to direct participation by communities in REDD+ in Indonesia include issues of both scale and capacity, but current carbon finance mechanisms do not incorporate plans to build their capacity.

The proposed regulation is not accompanied by instructions for implementation, and therefore the mechanism by which the funds will be distributed remains unclear. The regulation does not provide details of the conditions under which actors will be eligible to receive a share of REDD+ revenues, what reports or performance indicators will trigger transfers or how transfers will be linked to performance.

The proposed regulation is also unclear about how the price of carbon will be set at national level and whether transfer pricing rules will apply. Transfer prices will influence the taxes that the GoI will receive from carbon revenues. As shares of the revenues will be distributed amongst various participants, the 
transfer price will determine the actual amount each participant will receive. Transfer prices may be set either as the original price of the carbon bought or at a reduced rate. Transfer pricing includes setting, analysing, documenting and adjusting charges made between related parties (or components of an enterprise) for goods, services or use of property (including intangible property). Transfer prices may be used to reflect allocation of resources amongst parties or components of an enterprise, when they are treated as separately run entities, or for other purposes. The OECD Transfer Pricing Guidelines state that 'Transfer prices are significant for both taxpayers and tax administrations because they determine in large part the income and expenses, and therefore taxable profits, of associated enterprises in different tax jurisdictions' (OECD 2010). In the case of REDD+, the revenue of all participants along the chain of a carbon deal and revenue distribution - brokers, the GoI, communities and developers - will be influenced by how transfer prices are set.

Depending on how the market will operate, brokers of carbon deals or the GoI, or both, may end up determining transfer prices. The level of the transfer price relative to the actual price of carbon and the agency that sets that price will determine how much revenue is left for distribution (even the government's share, if the price is set by brokers) and how much developers and communities receive as absolute amounts. Depending on who sets the transfer price, REDD+ may enrich some parties that have done little or nothing to preserve the forests. Finally, transfer pricing is also likely to have a significant influence on the competitiveness of REDD+ compared with other forest uses.

An illustration of this risk is a recent sale and transfer of rights to the sale and marketing of carbon credits generated by forests in Aceh's Ulu Masen block, which spans 700000 ha. According to The Jakarta Post, the Aceh government signed an agreement in July 2008, giving Carbon Conservation of Australia - a carbon brokerage - exclusive rights in marketing and trading Aceh's forest carbon credits (Jakarta Post 2011c). The press has since reported that Carbon Conservation has sold off the rights as well as a significant amount of credits to a Canadian mining firm, East Asia Minerals. Press reports suggest that the contract gave East Asia Minerals exclusive rights to sell and market any credits generated by the project (Hasan 2011). In both cases, there is an exclusive relationship that allows the company marketing the carbon credits to manipulate the price and set it at levels significantly lower than the market price. In addition, in an exclusive buyer relationship, as was the case with the mining company, the buyer may be willing to pay an even lower price. Thus, the risks of price manipulation are even higher in an exclusive relationship, especially when both the brokerage and the buyer have exclusive rights.

\subsection{Lessons and risks for benefit sharing in REDD+}

A lot is at stake with the distribution of benefits, and numerous actors and stakeholders are involved. As benefit-sharing decisions will influence choices on REDD+ investments (i.e. their type, objectives and locations), it is important that these decisions be made in a transparent and inclusive way. However, few public discussions have been held to try to clarify positions and issues, and it is unclear which agency will ultimately be responsible for managing the distribution. These conditions may facilitate closeddoor deals.

Several risks are associated with benefit distribution, some of which are implicit in current proposals; others must be anticipated and addressed in the final mechanism.

As the current proposal for the distribution of benefits and past experience with reforestation and afforestation suggest, there is a risk that REDD+ projects will not provide additionality and/or the validity of their emission reductions will be doubtful. These risks compound the existing risk that additionality will be manipulated, as occurred in some CDM projects. If such risks materialise, they will lead to de facto fraudulent payments and REDD+ will be ineffective.

The proposal also foresees incentives for activities such as logging and timber concessions associated with companies that have traditionally benefited from the forestry sector and forest finance schemes, are politically connected and have a poor track record in meeting contractual obligations (Barr et al. 2010). If past patterns are repeated, despite current efforts to 
reduce opportunities for fraudulent gain, companies associated with these patterns will not only obtain undeserved benefits from REDD+ but will do so by violating the spirit of the regime. In addition, some international organisations currently involved in REDD+ projects or with the stated intention of running such projects have been involved in other schemes to reduce exploitation of natural resources and conserve forests in tropical countries. Review of their performance in achieving their objectives can help to mitigate risks. Risks also arise in relation to the exclusion of communities from direct participation in REDD+. 


\section{The REDD+ project implementation framework}

Many entities - the GoI, provincial governments, donors, companies, NGOs and communities - are involved in a wide range of REDD+ demonstration or pilot projects in Indonesia. More than 30 such projects were underway by mid-2010 (see Table 1 ), and their number has been growing rapidly (Kanninen 2010). How these projects are licensed under REDD+ is another area susceptible to potential, likely petty, corruption.

\subsection{Forest concessions and licensing}

Regulations and authorities for issuing licences and permits function as instruments to implement land use policies. According to MoF Regulation P.30/ Menhut-II/2009, REDD+ developers can - and should - use the existing licensing processes and apply for existing types of concessions and permits. The concession type depends on the type of forest management activity, which in turn depends on the forest function (Law No. 41/1999). All types of forest-related activity such as logging, timber plantations, ecosystem restoration and others are allowed in production forests. Protection forests cannot be used for timber or non-timber production. Conservation forests are regulated separately.

Protection and production are linked to 4 basic types of concession with multiple variations and rules (Table 3). A range of permits or concessions for forest use are available, based on the definitions of forest management and use: area use permit (IUPK), environmental services use permit (IUPJL), timber concession permit (IUPHHK), non-timber concession permit (IUPHHBK), timber collection permit (IPHHK) and non-timber collection permit (IPHHBK). The first 4 permits are basically largescale concessions, and the last 2 - the collection permits - are issued for smaller businesses, smaller areas and shorter durations. Some types of concession have variations. For example, logging concessions (IUPHHK-HA), ecosystem restoration permits (IUPHHK-RE) and timber plantation concessions (IUPHHK-HT) are variations of the timber concession permit.

Large-scale concessions generate most of the forest revenue for the government. Although the number of logging concessions has been in decline since the mid-1990s, currently most concessions in Indonesia are large-scale logging concessions; in total, there are 304 such concessions covering more than 25 million ha of production forests (Table 3).

A concession is granted in response to an application by a company or community. The process does not involve tenders. Concession areas are not identified by the issuing authority but by applicants.

The rules specifying which level of government is authorised to approve each type of concession have changed several times since 1999. The current regulations authorise 3 levels of government to issue permits. The MoF can approve and grant largescale plantation permits. A governor (gubernur, the head of a province) can issue permits for non-

Table 3. Forest concessions in Indonesia

\begin{tabular}{lccl}
\hline Type of licence & Number & Area (thousand ha) & Notes \\
\hline IUPHHK-HA (logging, natural forest) & 304 & 25041.9 & $\begin{array}{l}\text { Large-scale concessions with long } \\
\text { timeframes } \\
\text { Generate the most revenue for Gol }\end{array}$ \\
IUPHHK-HT (timber plantation) & 236 & 9356.3 & $\begin{array}{l}\text { Issued for smaller businesses and } \\
\text { smaller areas }\end{array}$ \\
\hline IUPHHBK-HT (non-timber, plantation forest) & 1 & 40.7 & \\
IUPHHK-HTR (community timber plantation) & 42 & &
\end{tabular}


timber concessions. A bupati (head of a district) can issue small-scale community permits. MoF-issued permits require a technical recommendation by the relevant subnational government. Concessions issued by subnational governments require approval or verification by the $\mathrm{MoF}$ or its technical implementing units. Depending on the type of permit and the autonomy or decentralisation laws in effect for a given province or district, concessions are issued at the discretion of forestry officials in the MoF or the respective government (head of province or district). It is important to note that although the stated aim for delegating the authority to award permits is to simplify the licensing process, a long process is involved with a bupati or a gubernur issues a permit.

Currently, there are 4 basic models for REDD+ pilot projects, depending on the developers, status of the concession (existing or applied for) and ability or aim to generate carbon credits. These models are (1) concession model, either using traditional logging or timber plantations or using ecosystem restoration concessions; (2) land user partnerships, where a proponent makes an agreement with existing land users to develop and share the carbon credits from a pilot; (3) government partnership, where a proponent enters into partnership with the government; and (4) no carbon rights, where a proponent supports government programmes without seeking a share of the carbon rights (Madeira et al. 2010). Of 17 assessed REDD+ pilot projects in Indonesia in 2009, 8 applied for a new concession; of these, 7 were applications for an ecosystem restoration concession or its provincespecific equivalent in Papua (model 1). The ecosystem restoration system allows the establishment of longterm $(60+35$ years) tenure security and is likely to be most attractive for REDD+.

However, the basic models above do not reflect the rich variety of arrangements evident in current REDD+ pilot projects. Different projects use different pieces of legislation operating at different scales. For example, in 2007 the government of Aceh, Carbon Conservation and Fauna \& Flora International started a REDD+ pilot with a provincial licence (permit for ecological service use) using the laws granting autonomy to the province of Aceh.

Applicants for a REDD+ permit are required to have existing concessions and permits (see Table 3) for areas that meet REDD+ location criteria, REDD+ implementation plans and, depending on the concession, recommendations from the relevant subnational governments. Criteria and requirements, including identification of threats to forests, absence of competing claims, clear tenure, annual MRV of concessions, are defined in MoF regulations P.30/ Menhut-II/2009 and P.36/Menhut-II/2009.

Approval of a REDD+ permit involves the Minister of Forestry and the Commission on REDD+. The commission has a mandate to analyse the application and submit a report, with recommendations, to the minister. Based on this report, the minister has the authority to approve or reject the request. The process does not include the full involvement of third parties but is nevertheless more open than the concession approval process.

\subsection{Risk of corruption in REDD+ licensing}

The current licensing processes for forest concessions can create conditions that are conducive to corruption and fraud. First, there is no tendering procedure or third-party involvement in the review and approval of applications. Decisions are concentrated amongst individual forestry officials at various levels. This allows the Minister of Forestry or other civil servants (depending on the permit) to exercise broad discretion in a process that is not transparent.

Second, the system of concessions and permits involves a range of functions, scales, durations and other variables. This complexity creates a barrier to transparency.

Regulations require applicants to determine the forest condition and ascertain that the area is free from any existing rights. However, there are no mechanisms to ensure that these criteria are met. Although timber plantation and ecosystem restoration concessions and permits should be issued only for degraded forests that are free from competing rights claims, many are located on land with good forest conditions. Even some REDD+ proponents fail to meet all criteria. For example, the Fauna \& Flora International application is for an area in West Kalimantan already occupied by oil palm plantation and timber concessions. 
Difficulties in land identification and missing data may also prevent applicants from meeting the criteria for land suitable for specific types of permits and allow misuse and manipulation, which may involve bribes.

The Nastra establishes a technical carbon threshold for land suitable for low-carbon development, as well as for land meriting conservation purely for its carbon storage potential (GoI 2010). However, specific areas have not been identified. It is much more profitable to establish a timber or ecosystem restoration concession on land with standing trees and good forest condition, either because it can be logged to provide additional revenue and then replanted, or because much less investment will be needed for planting. Incentives exist to establish REDD+ projects in forests that are in good condition but are identified in the permit as degraded.

Further, licensing regulations contain numerous loopholes. The KPK identified 17 systemic weaknesses that allow abuse and open the way for illegal logging, forest conversion and other destructive activities (Jakarta Post 2010b, Kompas 2010e, KPK 2010c). Some loopholes are related to the licensing role of district and provincial governments, whose technical recommendation is required for some concessions but not others; although forestry regulations state that $\mathrm{MoF}$ approval is required, other general laws give these governments autonomy and discretion. These contradictions and inconsistencies confuse mandates and allow discretionary decisionmaking. Subnational governments can use their mandate to slow down or avoid approval by the MoF. Data from a recent review of concessions and permits in Central Kalimantan by a cross-agency team show that an overwhelming number of plantation and mining companies operate without $\mathrm{MoF}$ approval or permits. The team found that of the total 967 plantation and mining firms in the province, only 76 companies had legal permits. Only 67 of 325 plantation companies, operating over a total area of 4.6 million ha, had permits from the MoF. Only 9 of the 615 registered mining companies in the province held permits to convert forests on an area totalling 30000 hectares (Anti-Judicial Mafia Taskforce 2011, Jakarta Post 2011b). In addition to the questionable legality of these operations on vast areas of land, it is also highly likely that the activities compete with legally established or traditional claims on those lands.

Further, the existence of multiple authorities, concentrated amongst specific individuals, prevents the screening of proponents. Various media reports suggest that all kinds of companies, individuals and groups - some of which may not have clean environmental track records - are either already involved or seeking to get involved in REDD+ (Coelho 2010, Ecologist 2010, Guardian 2010).

A recent survey indicates that large international NGOs and charities are involved in more demonstration activities than any other type of actor. First amongst them are the World Wide Fund for Nature (WWF), Conservation International and Flora \& Fauna International (Cerbu et al. 2011), which derived the greatest benefits and were most heavily involved in achieving the environmental objectives of swaps. Three NGOs, WWF, The Nature Conservancy and Conservation International, received the bulk of the debt-for-nature subsidies in 5 Latin American countries (Occhiolini 1990, Thapa 2000). Checking their track record may be useful for informing REDD+.

Corruption, bribery and fraud in the licensing process are facilitated by the absence of attention to conflicts of interest (Tanzi 1998, KPK 2009, Bappenas official, interview 2011). Companies currently licensed to operate in forests obtain unwarranted permit renewals, conduct unlicensed activities or encroach on areas not covered by the permit (private sector, interview 2011). There are indications that logging and other companies operate without licences by bribing forestry officials in the field to obtain their cooperation. This pattern could be replicated in REDD+, where companies licensed to develop REDD+ projects can conduct unlicensed activities or encroach on areas beyond their permit area. Corruption at local level can facilitate such practices.

The main characteristics that facilitate corruption and fraud in licensing, therefore, are closed-door decisionmaking, lack of transparency and accountability, high transaction costs caused by long and complex procedures, different levels of decision-making authority, opportunity for decisions favouring self- 
interest, failure to manage conflicts of interest and dependence of officials and their departments on vested interests. One outcome of corruption in the licensing process is the failure to meet the criteria for forest condition in concession areas. Related risks are failure to ensure additionality and real emission reductions. Such structural flaws are of critical importance for REDD+ because they will allow proponents to manipulate reference levels and accounts, encourage them to deforest before the start of the accounting period and/or receive payments for non-performance. A second outcome may be the violation of existing tenure rights and incitement of tenure conflict. 


\section{Forest revenues and reconciliation of accounts}

REDD + offers potentially large inflows of money from conserving remaining forests and rehabilitating degraded forests. Assuming a carbon price of US $\$ 5$ per ton, Purnomo et al. (2007) estimate that a 5\% reduction in the deforestation rate from the businessas-usual level could potentially generate annual REDD+ payments to the value of US\$765 million. This is about twice the size of the MoF's 2009 annual budget (Republik Indonesia 2009). If the targeted emission reductions and associated payments actually materialise, the amounts would be sufficient to offset the potential loss in ministry revenues incurred from cessation of activities associated with the exploitation of forests. However, past experience points to several weaknesses in financial management and administration of forestry revenues (Barr et al. 2010).

An area of REDD+ in which corruption and fraud are possible - and likely - is the reconciliation of accounts between project credits and national credits in a nested approach (Brown 2010). The REDD+ carbon emission reductions accounting system has not yet been set but will involve the reconciliation of project reports into a national account. Because REDD+ is performance-based, it will be particularly important to reconcile performance and payment records at all levels. In this sense, REDD+ will involve bottom-up (performance), top-down (payments) and horizontal (performance and payments) report reconciliation. Architects of the REDD+ accounting system can learn from past experience with tax and production report reconciliation.

Several questions arise: Is the system clear, straightforward and relatively easy to implement? Is it transparent? Are there accountability mechanisms in place and does it create opportunities for rentseeking? Are the transaction costs high? Are there incentives to comply with the law? (Noordwijk et al. 2008).

\subsection{Report reconciliation across scales}

Forest concessions in Indonesia are subject to taxation. ${ }^{4}$ The MoF listed 8 types of revenue from forest fees and taxes in its 2009 statistics report $(\mathrm{MoF}$ 2009); 5 of these, the 3 main sources of government revenue from the forestry sector are the forest concession licence fee (Iuran Ijin Usaha Pemanfaatan Hutan; IIUPH ${ }^{6}$ ), the Reforestation Fund (Dana Reboisasi; DR) and the forest resource rent (Provisi Sumber Daya Hutan; PSDH). All concession types must pay all 3 fees, although at different rates. These 3 taxes and fees have accounted for an average of $99.95 \%$ of the government's annual revenue in the forestry sector since 2004, but the absolute amount has been steadily declining: in 2009, it was less than half of the 2004 amount.

In addition, forest concession holders are subject to taxes imposed by other ministries. For example, they are required to pay land and building taxes and corporate income taxes, which are administered by the Ministry of Finance. Concession holders also pay fees to provincial and district governments, for purposes that vary across regions, and a fee for community development (Pembangunan Masyarakat Desa Hutan; PMDH).

The rules that define how taxes are paid and collected and reports are reconciled have changed several times since they were first introduced. Currently, forestry taxes and fees are defined in

4 In Indonesian public finance systems, these are classified as 'non-tax state revenue' (penerimaan negara bukan pajak), although in practice they are similar to taxes.

5 These are: revenues from fixed charges (Pendapatan Iuran Tetap), Reforestation Fund (Dana Reboisasi), Forest Resource Rent Provision (Provisi Sumber Daya Hutan), Forest Concession Fee (Iuran Hak Pengusahaan Hutan), Forest Security Fund (Dana Pengamanan Hutan), Penalty Fee for Violations in Forest Exploitation (Denda Pelanggaran Eksploitasi Hutan) and Fee for Transporting Wild Animals and/or Plants (Iuran Mengangkut Satwa Liar atau Tumbuhan Alam).

6 The IIUPH was formerly called Iuran Hak Pengusahaan Hutan (IHPH). 
MoF Regulation P.18/Menhut-II/2007 (Figure 2). Nine entities and offices at various scales and in various agencies are involved in paying, collecting and reconciling tax and, in some cases, production reports: (1) the company; (2) the tax collection officer (pejabat penagih); (3) the head of the district forestry office; (4) the head of the provincial forestry office; (5) the head of the technical implementing unit under the directorate general of forest

production at the MoF; (6) the treasurer of the MoF; (7) the secretary-general of the MoF; (8) the director general of forest production at the MoF; and (9) banks. In addition, other actors outside the forestry sector are involved in the forest finance system, amongst them the companies that generate the reports, commercial banks, the Ministry of Finance at central government level and the government secretariat at provincial and district levels. The $\mathrm{MoF}$ has to reconcile the forest revenues in its bank account with the budget reports that districts and provinces submit to the Ministry of Finance. The process of report reconciliation involves 11 steps from the appointment of a tax collector by the head of the district forestry office to the point where the director general of forest production receives the consolidated report of actual tax receipts.

Many of the same reports from different sources are reconciled in one office; other reports are not submitted from lower to higher levels (e.g. quarterly reports are reconciled at district level). Still other reports, such as annual reports, are submitted to higher levels but not to middle levels (e.g. annual reports from companies) or top levels (e.g. annual reports are submitted by companies to the technical unit but not passed on to the MoF secretary-general). Some links are totally missing. For example, the treasurer checks the balance at the bank but does not receive any reports. Companies generate production reports on an annual basis and submit them, along with their annual tax reports, only to the district and provincial offices and the technical unit. Only monthly tax reports are reconciled into quarterly and semi-annual reports, and only monthly reports are circulated through the whole MoF chain. The MoF is responsible for reconciling company and provincial reports with its own timber production data, but the system does not reconcile company production with tax reports or those reports with the permits. Some of these gaps are illustrated in Figure 2.
Gaps in the system prevent the full reconciliation of reports and allow avoidance of payments and violations of permits. Further, reconciliation is a cumbersome process, and the BPK found some cases in which reconciliation was not done on a regular basis, if at all (BPK 2008). Having duplicate and triplicate submissions of the same reports increases both the company's transaction costs and the administrative costs borne by the MoF.

\subsection{Risks of corruption in REDD+ accounting}

The current system for collecting forest concession fees and taxes and reconciling reports allows unlicensed activities in forest areas and manipulation of production and tax reports. Although the regulations on forest taxes are very detailed, loopholes remain, as suggested by findings from the BPK from 2004 to 2008. Examples indicate contradictions in several regulations, for example, between the regulations that establish penalties for late payment (PP.59/1998, PP.74/1999, PP.92/1999; Ministerial Decree P.18/Menhut-II/2007).

Inconsistencies create opportunities for different interpretations by forest authorities and manipulation by companies (e.g. manipulation of the exchange rate or bank guarantees). The complexity of the reporting structure and the changing regulations constitute a barrier to transparency and accountability: it is difficult to build a system of transparency and accountability across agencies and scales and for a variety of payments. It is also difficult to monitor and ensure that all fees are paid and reports are fully reconciled. The system allows companies to falsify documents, evade taxes and cover up illegal logging or other violations of the permits. ${ }^{7}$

The BPK has found that the MoF does not regularly reconcile balance sheets with the Ministry of Finance. Because the MoF does not have the control systems to ensure that all due payments have been made, the revenue reports are not reliable, and neither are the production reports (BPK 2008). Invoices and proof of payment can be manipulated for the purpose of

7 One example is the case of Nirwan Rangkuti and Susilo Setiawan in 2007, in which a forest product transportation permit was falsified. 

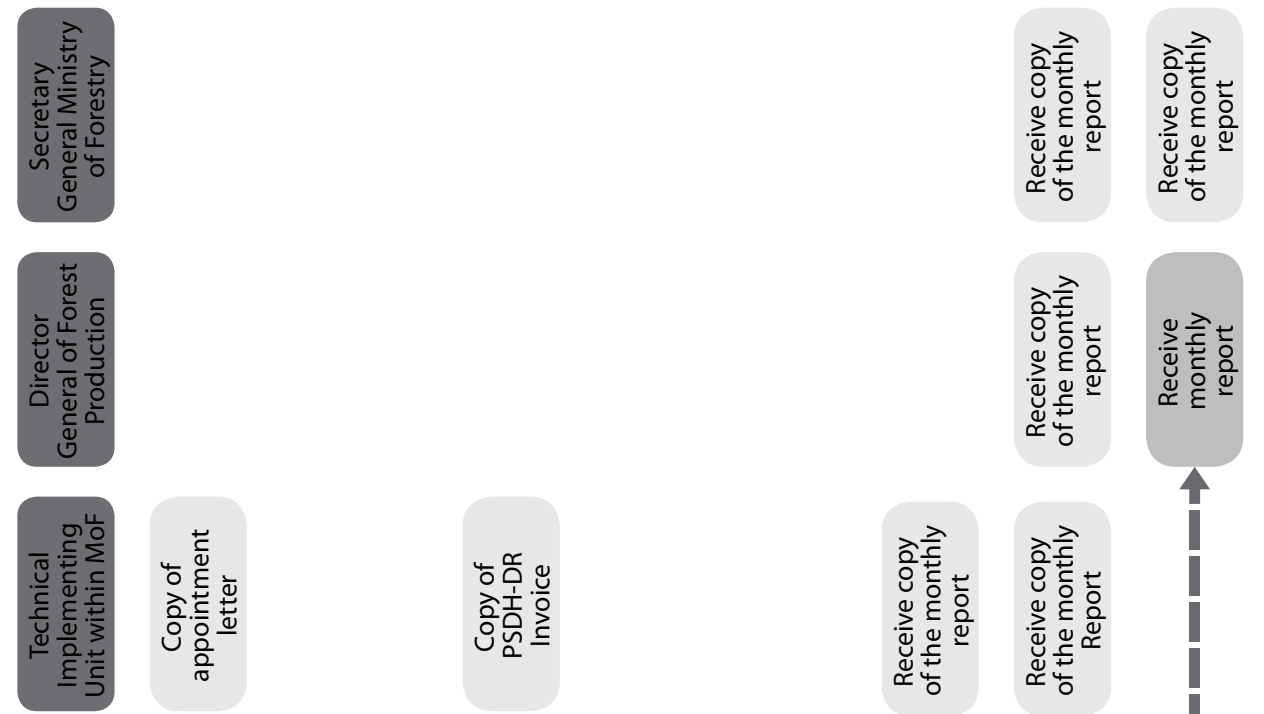

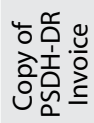
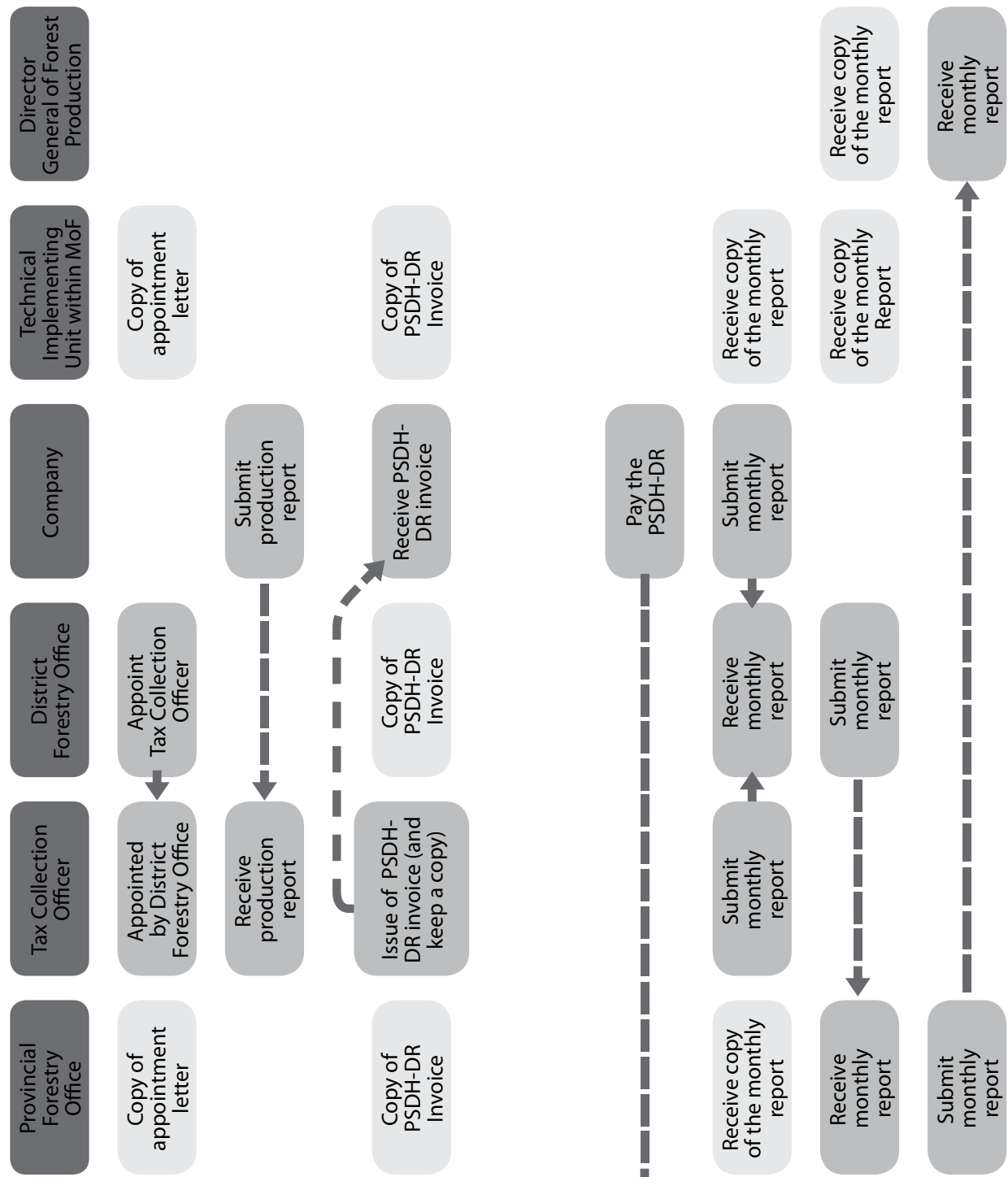

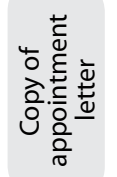
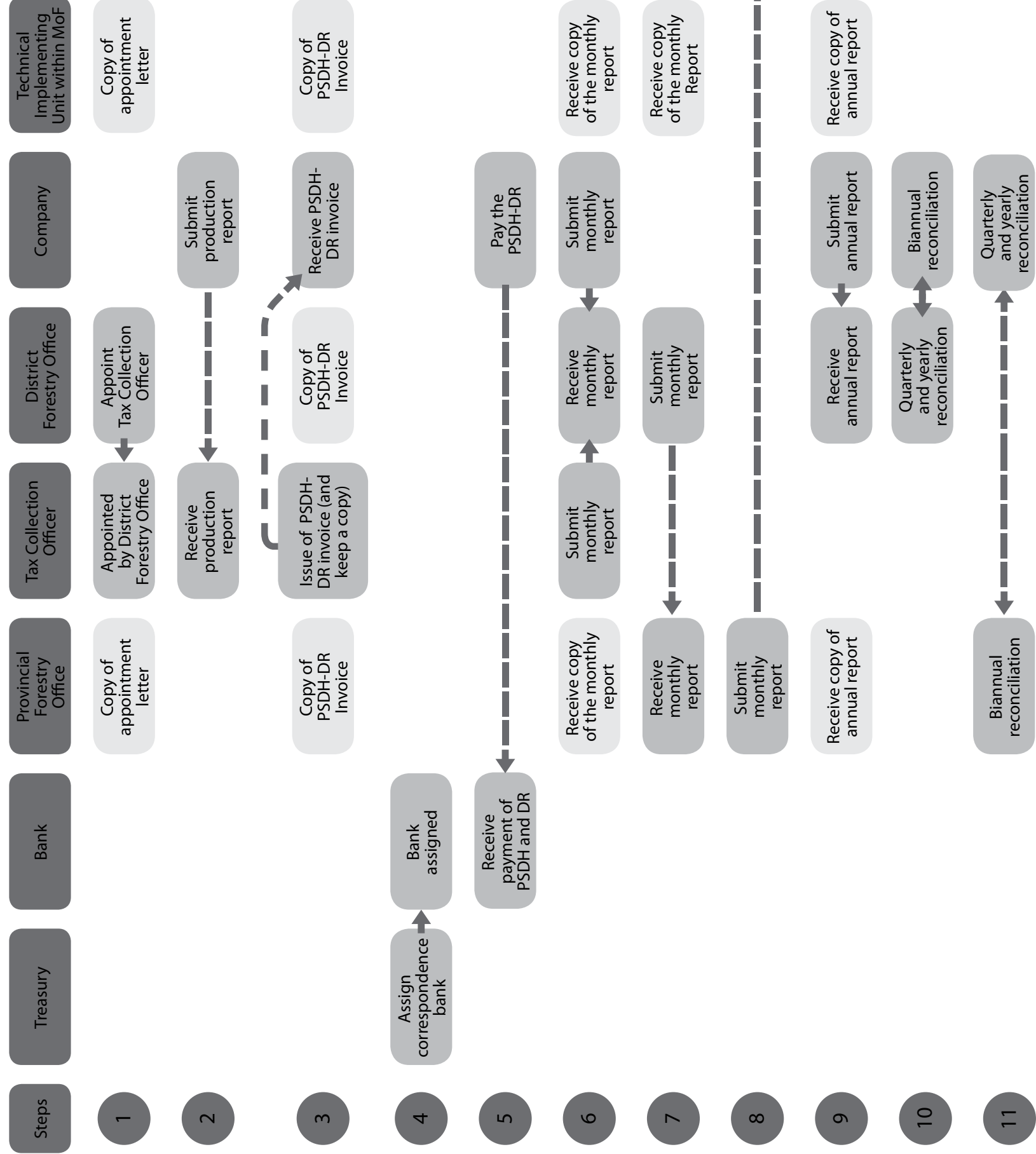

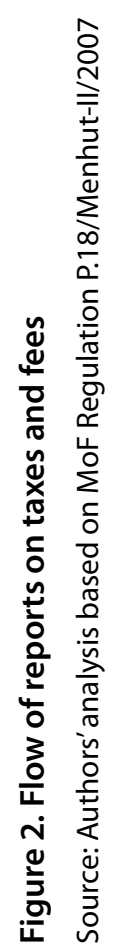


evading taxation. Corruption is also possible during reconciliation and administrative monitoring of invoices and production reports.

Cumbersome and inconsistent regulations, high transaction costs attributable to multiple levels of reconciliation and reporting, missing links in report reconciliation, absence of monitoring of performance and other problems, if replicated, will create risks for REDD+ by allowing proponents to over-report emission reductions and create discrepancies between national and project accounts and/or skew national accounts. 


\section{Conclusions and recommendations}

The GoI has made significant progress in preparing for REDD+ by introducing policies and regulations, creating coordinating mechanisms and initiating demonstration projects. The GoI is taking steps to curb corruption and money laundering generally and in the forestry sector specifically by strengthening legislation and involving independent agencies in monitoring forest-related activities and institutions. Nevertheless, the risk of corruption in REDD+ remains. Efforts to curb corruption are relatively recent in Indonesia, and the nation's legal framework and institutions - such as the KPK and the PPATK - are still young.

The readiness phase in Indonesia involves a wide range of reforms and decisions. Some of these will have long-term impacts on the winners and losers from forest-related activities. Other initiatives are trying to establish clearer regulatory procedures for REDD+. Both will influence how successful REDD+ will be during the implementation phase, and how it will function in practice. Therefore, corruption - or its prevention now - will influence who will benefit from REDD+ later and how it will be implemented.

As Section 4, 'REDD+ policymaking', suggests, corruption in the REDD+ policy arena is likely to undermine efforts to reduce forest conversion through, for example, manipulating land classification, misclassifying intact forest as degraded land so that it can be legally destroyed for commercial purposes and manipulating land titles. It is also likely to influence the design of new policies and institutions, so that corrupt practices can continue under REDD+. If the risks of corruption materialise, it is likely that little long-term land use change will occur and tenure problems will not be addressed. Failure to address these issues will compromise the government's sustainable development objectives and prevent the national strategy on REDD+ from aligning development and climate change mitigation goals. In the short term, baselines may be skewed and, in the absence of geographical information about forest conditions and boundaries for permitted activities, decisions and practices may lead to illegal deforestation and land grabs.
The main determining factor for corruption in policymaking is the presence of vested interest groups with powerful connections with much to lose or gain. Ambiguous authority, leadership, roles and mandates, inconsistent policies, opportunities for discretionary decision-making and a lack of accurate or clear data are all features of the Indonesian system and facilitate corruption or allow undue influence on decision making.

In the past, poor financial management capacity, elites that act outside the law and the absence of accountability mechanisms, including monitoring and verification of reports and financial transactions, have led to corruption and misuse of forest funds. If replicated or not adequately addressed, these conditions could engender significant risks of corruption in climate finance in Indonesia. These risks are compounded by threats to the effectiveness of REDD+ as emerging climate finance schemes in Indonesia inadequately address tenure issues and capacity building of local institutions.

Corruption and fraud could also affect the distribution of revenues. Experience shows that connected networks of vested interests in the private and public sectors have poor track records in meeting contractual obligations and administering forest revenues. As explained in Section 7, if past practices and patterns are replicated, REDD+ projects' additionality will be compromised and payments will be distributed despite non-performance. The current proposal, even though it allocates significant revenue shares to communities for some types of REDD+ activities, does not foresee measures to make effective participation possible. In addition, there is the risk of manipulation of transfer prices and loss of revenues for both forest-dependent communities and the government.

Corruption in the REDD+ licensing process is most likely to occur when determining whether concession areas meet the specified forest condition criteria. This risk is of critical importance for REDD+ because, should it materialise, it will allow REDD+ concession holders to deforest before the accounting period begins, 
thereby altering baselines and skewing national carbon accounts. Corruption in the licensing process may also lead to large-scale land grabs, violation of existing tenure rights and conflicts over land, where the main losers will be traditional communities governed by customary law and people who depend on forests.

The current system for reconciling forest production and payment reports is inadequate. If it is replicated within the REDD+ mechanism, it will undermine accurate credit accounting and foster corruption, allowing proponents to claim undeserved credits. It may even allow proponents to continue with business as usual whilst profiting from carbon credits. Ultimately, this will skew national accounts and have implications for the integrity of the global REDD+ regime.

The main conditions for corruption in the readiness phase and its likely outcomes are set out in Figure 3.

The risks of corruption associated with REDD+ arise, therefore, in several ways. One is undue influence by politically connected networks both in the policy arena and at project level. Policy coopting can affect, for instance, forest land use, the issuance of permits, additionality, the distribution of funds and access to and profits from carbon markets or even the accounting of emission reductions from projects.

REDD+ is likely to be associated with increasing funds and opportunities for both profit and corruption. There is always a risk of corruption when monetary sums are huge and the markets and mechanisms that money will flow through, such as REDD+, are young, untested and evolving (Transparency International 2011).

Both the international negotiations under the UNFCCC and the progressive shifts in centres of power and leadership in the domestic REDD+ debate in Indonesia are characterised by high levels of uncertainty. Confusing regulations, missing information and data and competition over authority, rights and land have created a complex landscape

\section{Readiness phase in Indonesia}

REDD+ policies and measures

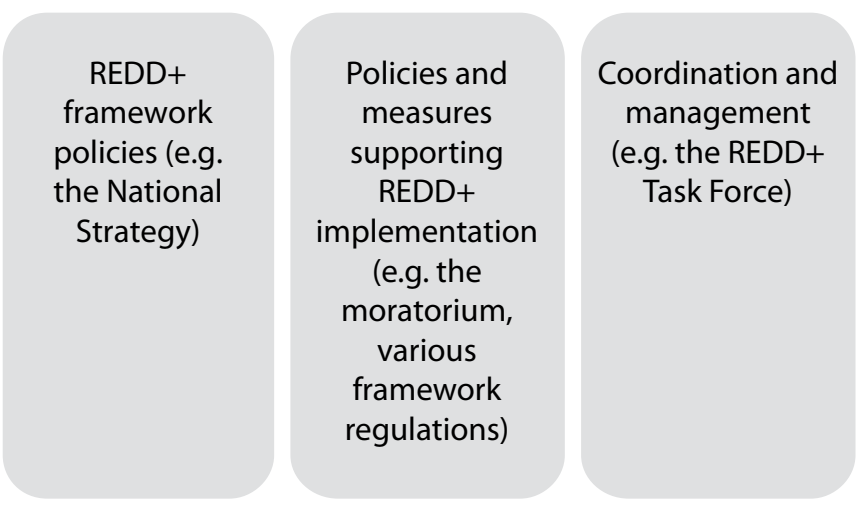

REDD+ demonstration projects

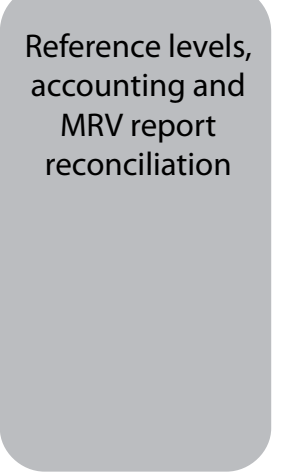

Policies and
measures
related to
REDD+ project
implementation
(e.g. licensing)
Decisions and activities related to REDD+ project implementation (e.g. selection of pilot provinces, REDD+ demonstration projects)

Conditions for corruption: regulatory loopholes and inconsistencies; closed-door, discretionary decision making allowing undue influence; powerful, connected networks of vested interests; lack of transparency and accountability mechanism; flawed process; absence of data and information to support decisions; insufficient coordination

Outcomes: elite capture, violation of existing rights and conflicts over land, land grabbing, and increased deforestation, skewed performance and payment reports in a nested system

Figure 3. Corruption risks and outcomes in the REDD+ readiness phase 
and increased the uncertainty. Such complexity and uncertainty heighten the risk of corruption, which could influence the REDD+ design, thereby ensuring vested interest groups continued access to forest resources. This will also undermine trust $-\mathrm{a}$ critical condition for any market.

In developing and instituting policies, licensing and benefit-sharing rules, there is a risk of creating structural flaws and perverse incentives that allow inventive accounting, projects that produce no additionality, reporting of fictitious emission reductions, double counting, manipulation of baselines, misrepresentation of projects and other ways to factor in undeserved profit. These are likely to involve some degree of corruption as well.

The critical policy issues that need to be addressed to limit corruption and manipulation of decisions relate to:

1. clarifying state forest boundaries and recognising forest and land tenure of community and indigenous people

2. integrating the objectives outlined in the National Strategy into land use policies

3. clarifying and consistently applying criteria for conversion of forests

4. closing regulatory loopholes

5. generating data and making that data publicly accessible to support informed policymaking.

The GoI is already working to address some of these issues. Other issues have been recognised but no decisions have been made. Many of these decisions are difficult to make and cannot be implemented overnight. Therefore, it is important to prioritise and establish clear timeframes and deadlines. Such prioritisation is important both for the government and its ability to monitor its own progress as well as for donors, business interests and the public. It will create a predictable policy environment that nevertheless adjusts to the dynamic REDD+ environment, including a REDD+ market. Creating systems to monitor progress in introducing policies and achieving objectives is an important step in ensuring accountability and reducing the risk of corruption. In doing so, consideration should be given to key questions such as the following.
1. What are the benefits and risks of engaging existing agencies versus creating new institutions?

2. What capacity is needed for each issue, and are there cost-effective ways to build that capacity?

3. Which is the right level or agency to perform each task associated with REDD+?

4. What risks and opposition are likely for each decision option?

Addressing the issues listed above will help create a predictable and stable policy environment and reduce turf battles, opposition and risks.

Apart from ensuring a stable, predictable and clear policy environment, the GoI can take several other measures to prevent or limit corruption. One is transparency. A fully transparent and inclusive process that clearly defines development options and stakeholder positions will reduce opportunities for closed-door deals on policies and rules.

Curbing corruption also requires clearly defined leadership, decision-making and implementation roles for the various agencies involved, clear priorities for action with set timeframes and publicly accessible, geo-referenced, up-to-date information about forest locations, conditions and activities. The GoI can take specific steps to address these issues and improve transparency.

Many of these steps will also help increase agencies' accountability. Introducing processes for accountability and independent oversight and review is important for various ongoing efforts across the board. This requires that checks and balances are built into REDD+ core structures, be they ones that implement policies or manage REDD+ funds, accounts or reports. A clear separation of mandates and functions is also recommended. Given past experience with forest finance in Indonesia, special consideration should be given to the introduction of systems for independent financial monitoring and oversight as well as to significant investment in building financial management capacity and strengthening national government ownership. Reviewing systems for report reconciliation and streamlining will also limit opportunities for manipulation and corruption. National institutions 
entrusted with combating corruption and money laundering should be involved in financial monitoring and audits of climate finance.

Accurate and updated data supporting forest land classification for different uses inside and outside the forest estate and a stronger focus on high-value forests and their demarcation, combined with transparency and accountability, will limit corruption and manipulation of current efforts. Reporting progress to the public will further strengthen accountability.

Anti-corruption safeguards should be integrated as core elements in REDD+ design in Indonesia. Clarifying the roles and involving Indonesia's Corruption Eradication Commission, Financial Intelligence Unit and the Supreme Audit Agency in REDD+ will ensure that existing anti-corruption and anti-money laundering policies and rules are appropriately implemented and will help monitor processes, practices and key companies and individuals defined as politically exposed. However, different corruption risks require different measures and degrees of urgency. The current risks of corruption are highest in relation to policymaking and licensing. Policymakers are currently undertaking reforms to limit forest conversion. Land demarcation, generation of accurate data and closure of regulatory loopholes are likely targets for efforts to curb corruption as they will influence future land use and may inform more profound reforms. Licensing rules legitimise the numerous projects already underway and therefore also need urgent attention. As REDD+ evolves, the risk of corruption will increase in the distribution of REDD+ funds and the reconciliation of project reports.

The GoI cannot handle all of these issues on its own. International donors can play key roles in assisting it with its efforts. Donors could be involved not only in forestry - and related technical issues such as development of forestry maps or revenue administration within the technical agencies - but also in increasing the capacity of government staff at subnational levels and of the audit and anticorruption agencies. One particular focus could be to assist the GoI in meeting UNCAC requirements as well as providing the technical assistance and capacity building needed to implement them. 


\section{References}

Accra Caucus 2010 Realising rights, protecting forests: an alternative vision for reducing deforestation. Rights and Resources Initiative, Washington, DC. http://www. rightsandresources.org/documents/files/doc_1590. pdf (23 October 2011).

AgroIndonesia 2010a BUMN Hutan Cari Bentuk Baru. 15 November. http://agroindonesia. co.id/2010/11/15/bumn-hutan-cari-bentuk-baru/ (23 October 2011).

AgroIndonesia 2010b BUMN Hutan Dikerahkan Tanam. 23 November. http://agroindonesia. co.id/2010/11/23/bumn-hutan-dikerahkan-tanam/ (23 October 2011).

AgroIndonesia 2011 APHI Siap Gugat Menteri Kehutanan. 18 April. http://agroindonesia. co.id/2011/04/18/aphi-siap-gugat-menterikehutanan/ (23 October 2011).

Angelsen, A., Streck, C., Peskett, L., Brown, J. and Luttrell, C. 2008 What is the right scale for REDD? The implications of national, subnational and nested approaches. Infobrief No. 15. CIFOR, Bogor, Indonesia.

Antara 2010a US partnering with Indonesia to stem deforestation. 29 November. http://www. antaranews.com/en/news/1291029514/uspartnering-with-indonesia-to-stem-deforestation (23 October 2011).

Antara 2010b RI named facilitator at climate change conference. 7 December. http://www.antaranews. com/en/news/1291735602/ri-named-facilitator-atclimate-change-conference (23 October 2011).

Antara 2010c Indonesia gets $\$ 45$ million from Australia to address climate change. 9 December. http://www.antaranews.com/en/ news/1291869453/indonesia-gets-45-millionfrom-australia-to-address-climate-change (23 October 2011).

Antara 2010d Australia strong supporter of RI's climate change initiatives. 10 December. http:// www.antaranews.com/en/news/1291968737/ australia-strong-supporter-of-ris-climate-changeinitiatives (23 October 2011).
Antara News Jawa Timur 2010 Kuntoro jamin akui masyarakat adat pada REDD. 7 December. http://www.antarajatim.com/lihat/berita/50010/ kuntoro-jamin-akui-masyarakat-adat-pada-redd (4 November 2011).

Anti-Judicial Mafia Taskforce 2011 Penegakan hukum pada pelanggaran di kawasan hutan di Kalimantan Tengah (Press release). 1 February. http://www.satgas-pmh.go.id/?q=node/179 (23 October 2011).

Badan Pemeriksa Keuangan (BPK) 2008 Laporan hasil pemeriksaan atas laporan keuangan Departemen Kehutanan tahun 2007. BPK, Jakarta, Indonesia.

Barr, C., Dermawan, A., Purnomo, H. and Komaruddin, H. 2009 Financial governance and Indonesias Reforestation Fund during the Soeharto and Reformasi Periods, 1989-2009: a political economy analysis of lessons for REDD. CIFOR and World Bank, Bogor, Indonesia.

Barr, C., Resosudarmo, I.A.P., Dermawan, A. and Setiono, B. 2006 Decentralization's effects on forest concessions and timber production. In: Barr, C., Resosudarmo, I.A.P., Dermawan, A. and McCarthy, J. (eds) Desentralization of forest administration in Indonesia: Implications for forest sustainability, economic development and community livelihoods. CIFOR, Bogor, Indonesia.

Bisnis Indonesia 2010a Menhut lepas, 15 juta ha untuk pertambangan. 18 November. http://www. fkkm.org/web/artikel/menhut-lepas-15-juta-hauntuk-pertambangan/ (23 October 2011).

Bisnis Indonesia 2010b Kemenhut hanya lepas 24 juta ha. 24 November. http://bataviase.co.id/ node/468971 (4 November 2011).

Bofin, P., du Preez, M.-L., Standing, A. and Williams, A. 2011 REDD integrity: addressing governance and corruption challenges in schemes for reducing emissions from deforestation and forest degradation (REDD). U4 Anti-Corruption Resource Centre, Bergen, Norway. 
Bolongaita, E. 2010 An exception to the rule? Why Indonesia's anti-corruption commission succeeds where others don't. U4 Issue, August 2010.

Bonfante, T. M., Voivodic, M., and Filho, L. M. 2010 Developing social and environmental safeguards for REDD+: A guide for a bottomup approach. Imaflora, Sao Paulo, Brazil. http:// www.rainforest-alliance.org/sites/default/files/ publication/pdf/Developing_REDD_safeguards_ guide_ENGLISH.pdf (4 November 2011).

Bracking, S. 2007 Political development and corruption: why 'right here, right now!'? In: Bracking, S. (ed.) Corruption and development: the anticorruption campaigns. Palgrave Macmillan, Hampshire, UK.

Brockhaus, M., Obidzinski, K., Dermawan, A., and Laumonier, Y. 2010 Forest and land allocation policies in Indonesia - is the current framework sufficient to meet REDD+ needs? Paper submitted to International Conference-Forum 'Emerging Economic Mechanisms: Implications for ForestRelated Policies and Sector Governance', Rome, 5-7 October 2010.

Brown, M.L. 2010 Limiting corrupt incentives in a global REDD regime. Ecology Law Quarterly 37(1): 237-267.

Brown, J. and Peskett, L. 2011 Climate finance in Indonesia: lessons for the future of public finance for climate change mitigation. Working paper 11. European Association of Development Research and Training Institutes, Bonn, Germany.

Brown, T.H., Simangunsong, B.C.H., Sukadri, D., Brown, D., Sumirta, S., Dermawan, A. and Rufiie. 2005 Restructuring and revitalization of Indonesia's wood-based industry: synthesis of three major studies, industry restructuring synthesis. Ministry of Forestry, CIFOR and Department for International Development Multistakeholder Forestry Programme (MFP), Jakarta, Indonesia.

Business Monitor International (BMI) 2010 Indonesia mining report, includes 5 -year forecasts to 2014. BMI, London.

Businesswire 2010 Carbon conservation and APP introduce the world's first pulpwood plantation to carbon reserve REDD-plus initiative. 3 October. http://www.businesswire.com/news/ home/20101003005120/en/Carbon-Conservation-
APP-Introduce-World\%E2\%80\%99s-PulpwoodPlantation (23 October 2011).

Campos, J.E. and Bhargava, V. 2007 Introduction: tackling a social pandemic. In: Campos, J.F. and Pradhan, S. (eds.) The many faces of corruption: tracking vulnerabilities at the sector level, 1-25. World Bank, Washington, DC.

Caravani, A., Bird, N. and Schalatek, L. 2010 REDD-plus finance. Briefing paper, November. Overseas Development Institute, London.

Carbon Positive 2010 Indonesia moves on forest clearing moratorium. 20 October. http://www. carbonpositive.net/viewarticle.aspx?articleID $=2151$ (23 October 2011).

Cerbu, G.A., Swallow, B.M. and Thompson, D.Y. 2011 Locating REDD: a global survey and analysis of REDD readiness and demonstration activities. Environmental Science and Policy 14: 168-180.

Coelho, R.S. 2010 REDD: fuelling corruption and climate change. http://cooltheearth.wordpress. com/2010/11/02/redd-fuelling-corruption-andclimate-change/ (23 October 2011).

Contreras-Hermosilla, P. and Fay, C. 2005 Strengthening forest management in Indonesia through land tenure reform: issues and framework for action. Forest Trends, Washington DC.

Cotula, L. and Mayers, J. 2009 Tenure in REDD - Start-point or afterthought? Natural Resource Issues No. 15. International Institute for Environment and Development, London.

Cronin, T. and Santoso, L. 2010 REDD+ politics in the media. A case study from Indonesia. Working paper 49. CIFOR, Bogor, Indonesia.

Cronkleton, P., Bray, D.B. and Medina, G. 2011 Community forest management and the emergence of multi-scale governance institutions: lessons for REDD+ development from Mexico, Brazil and Bolivia. Forests 2: 451-473.

Deacon, R.T. and Murphy, P. 1997 The structure of an environmental transaction: the debt-for-nature swap. Land Economics 73: 1-24.

Deininger, K. and Binswanger, H. 2001 The evolution of the World Bank's policy. In: de Janvry, A., Gordillo, G., Platteau, J. and Sadoulet, E. (eds) Access to land, rural poverty, and public action, 406-440. Oxford University Press, Oxford, UK. 
Dermawan, A. 2004 Has the big bang hit the trees and people? The impacts of Indonesia's decentralization on forest conservation and the livelihood of communities. Unpublished M.Sc. Thesis, Agricultural University of Norway, Aas, Norway.

Direktorat Jenderal Penataan Ruang 2011 Status Perda RTRW. http://www.penataanruang.net/ (23 October 2011).

Down to Earth 2009 REDD concerns deepen. http:// dte.gn.apc.org/82acl.htm (23 October 2011).

Ecologist 2010 Shell funding of forest protection scheme could result in 'largest land grab of all time'. 8 September. http://www.theecologist.org/News/ news_round_up/589136/shell_funding_of_forest_ protection_scheme_could_result_in_largest_land_ grab_of_all_time.html (23 October 2011).

Eshelman, R. 2010 Indonesia’s Billion-dollar climate experiment: can rich nations pay a corruptionriddled government to protect its rainforests? Slate, 7 December. http://www.slate.com/id/2277046/ (23 October 2011).

Fauna \& Flora International (FFI) 2010 FFI and palm oil.www.fauna-flora.org/docs/FFI_and_Palm_Oil. pdf (23 October 2011).

Fay, C., Sirait, M. and Kusworo, A. 2000. Getting the boundaries right: Indonesia's urgent need to redefine its forest estate. Southeast Asia Policy Research Working Paper, No. 25. World Agroforestry Centre Southeast Asia, Bogor, Indonesia.

Fay, C. and Sirait, M. 2005. Kerangka hukum negara dalam mengatur agraria dan kehutanan Indonesia: mempertanyakan sistem ganda kewenangan atas penguasaan tanah. In: Tanah masih di langit: penyelesaian masalah penguasaan tanah dan kekayaan alam di Indonesia yang tak kunjung tuntas di era reformasi, 713-723. Yayasan Kemala, Jakarta, Indonesia.

Fernandez, R. and Rodrik, D. 1991 Resistance to reform: status quo bias in the presence of Individual specific uncertainty. The American Economic Review 81: 1146-1155.

Financial Action Task Force (FATF) 2006 Chairman's summary. FATF, Cape Town, South Africa.

Financial Crime Enforcement Network (FinCEN) 2010 Guidance to financial institutions based on the Financial Action Task Force publication on anti-money laundering and counter-terrorist financing risks. 18 March. US Department of Treasury, Washington, DC. http://www.fincen.gov/ statutes_regs/guidance/html/fin-2010-a003.html (23 October 2011).

Florini, A. 2007. The right to know: transparency for an open world. Columbia University Press, New York.

Forest Carbon Partnership Facility (FCPF) 2009 Readiness plan assessment note on environmental and social safeguards for a proposed REDD+ readiness program in Indonesia. Advisory Panel Review Participants Committee Meeting (FCPF PC3), Montreux, Switzerland, 16-18 June. http:// www.bicusa.org/en/Document.101276.aspx

(23 October 2011).

Forest Peoples Programme 2009 Indonesia: indigenous peoples and the Kampar Peninsula. Rights, forests and climate briefing series, October. http://www.ienearth.org/docs/Indonesia_rights_ briefing_oct09_low_res_eng.pdf (22 March 2011).

Fung, A., Graham, M. and Weil, D. 2003 The political economy of transparency: what makes disclosure policies sustainable? Faculty Research Working Papers Series RWP03-039. John F. Kennedy School of Government, Harvard University, Cambridge, MA.

Gatra 2003 CIFOR: UU pencucian uang, selamatkan hutan Indonesia. 18 September. http:// www.gatra.com/2003-09-18/artikel.php?id=31217 (23 October 2011).

Greenpeace 2010 REDD+ alert: protection money. Greenpeace International, Amsterdam, The Netherlands.

Government of Indonesia 2010 National strategy REDD (Revised 23 September). National Planning Development Agency, Jakarta, Indonesia http://www.un.or.id/sites/default/files/ COMPLETEStranas1RevisedEng\%20final $\% 20$ version.pdf (8 January 2011).

Government of Indonesia 2011 National strategy REDD (Published 17 August). UKP4. http://www.ukp.go.id/informasi-publik/doc_ download/12-draft-final-strategi-nasional-redd (23 October 2011).

Graycar, A. and Villa, D. 2011 The loss of governance capacity through corruption. Governance: An International Journal of Policy, Administration, and Institutions 24: 419-438. 
Guardian 2010 Massive corruption undermines forest protection plan. 27 October. http://www. guardian.co.uk/global-development/povertymatters/2010/oct/27/corruption-underminesforest-protection-plan (23 October 2011).

Hadad, M.D., Hall, M.J., Kenjegalieva, K., Santoso, W., Satria, R. and Simper, R. 2008 Efficiency in Indonesian banking: recent evidence. Discussion Paper Series 13. Department of Economics, Loughborough University, Leicestershire, UK.

Hasan, N. 2011 Aceh angry over sale of carbon credits to miner. The Jakarta Globe, 7 May. http:// www.thejakartaglobe.com/home/aceh-angryover-sale-of-carbon-credits-to-miner/439627 (23 October 2011).

Huang, M. and Upadhyaya, S.K. 2007 Watershedbased payments for environmental services in Asia. Working Paper No 06-07. Sustainable Agriculture and Natural Resource Management Collaborative Research Support Program, Blacksburg, Virginia, USA.

Indonesia Forest Climate Alliance (IFCA) 2010 REDD Indonesia: where are we now? Newsletter, May. http://www.dephut.go.id/files/IFCA_ newsletter2010.pdf (23 October 2011).

Info Sawit 2010 Regulasi moratorium harus jelas. July. p. 36.

Info Sawit 2011a Tujuh hambatan industri sawit 2011. February. p. 36.

Info Sawit $2011 \mathrm{~b}$ Ekspansi tersumbat moratorium. July. p. 10-13.

International Centre for Trade and Sustainable Development (ICTSD) 2011 Future of forest deal unclear as Indonesia fails to meet deadline. 24 January. http://www.illegal-logging. info/item_single.php?it_id=5178\&it=news (23 October 2011).

International Rivers 2008 Rip-offsets: the failure of the Kyoto Protocol Clean Development Mechanism. Case studies: dirty CDM hydros. http://www.internationalrivers.org/featured/85/461 (23 October 2011).Investor Daily 2010 Indonesia ditunjuk jadi fasilitator KTT iklim. 8 December. http://www.investor.co.id/international/ indonesia-ditunjuk-jadi-fasilitator-ktt-iklim/1350 (23 October 2011).

Jakarta Globe 2010a Indonesia readies \$1b 'green' fund to spur clean investments, reduce emissions.
27 January. http://www.thejakartaglobe.com/ home/indonesia-plans-1-billion-green-investmentfund/354921 (23 October 2011).

Jakarta Globe 2010b KPK: corruption jeopardizes lucrative climate-change deals. 17 September. http://www.thejakartaglobe.com/home/kpkcorruption-jeopardizes-lucrative-climate-changedeals/396726 (23 October 2011).

Jakarta Globe 2010c Indonesia sees no moratorium conflict in allowing mining in protected forest. 26 November. http://www.thejakartaglobe.com/ home/indonesia-sees-no-moratorium-conflictin-allowing-mining-in-protected-forests/408589 (23 October 2011).

Jakarta Globe 2010d Australia boosts support for REDD scheme with $\$ 45 \mathrm{~m} .10$ December. http:// www.thejakartaglobe.com/nvironment/australiaboosts-support-for-redd-scheme-with- $45 \mathrm{~m} / 411091$ (23 October 2011).

Jakarta Globe 2011 No more cutting natural forests, minister orders. 18 January. http://www. thejakartaglobe.com/home/no-more-cuttingnatural-forests-minister-orders $/ 417570$

(23 October 2011).

Jakarta Post 2002 Mega calls for logging moratorium. 13 May. http://www.rainforestrelief.org/ documents/Indo_Pres_Calls_Moratorium.pdf (23 October 2011).

Jakarta Post 2010a KPK warns ministry about problematic loopholes. 4 December. http://www. thejakartapost.com/news/2010/12/04/kpk-warnsministry-about-problematic-loopholes.html (23 October 2011).

Jakarta Post 2010b RI among 'main catalysts' in climate summit. 4 December. http://www. thejakartapost.com/news/2010/12/04/ri-among$\%$ E2\%80\%98main-catalysts\%E2\%80\%99climate-summit.html (23 October 2011).

Jakarta Post 2010c Weighing Indonesia's roles in emissions cut. 4 December. http://www. thejakartapost.com/news/2010/12/04/weighingindonesia $\% \mathrm{E} 2 \% 80 \% 99$ s-roles-emissions-cut.html (23 October 2011).

Jakarta Post 2010d Global climate deal under serious threat. 5 December. http://www.thejakartapost. com/news/2010/12/05/global-climate-deal-underserious-threat.html (23 October 2011). 
Jakarta Post 2010e Forestry and climate change: Cancun changes the game. 15 December. http:// www.thejakartapost.com/news/2010/12/15/ forestry-and-climate-change-cancun-changes-game. html (23 October 2011).

Jakarta Post 2010 f A victory for climate and the world's forests. 27 December. http://www. thejakartapost.com/news/2010/12/27/a-victoryclimate-and-world $\% \mathrm{E} 2 \% 80 \% 99$ s-forests.html (23 October 2011).

Jakarta Post 2011a RI risks businesses, forests with US $\$ 1 \mathrm{~b}$ forest moratorium delay. 6 January. http:// www.thejakartapost.com/news/2011/01/06/ri-risksbusinesses-forests-with-us 1 b-forest-moratoriumdelay.html (23 October 2011).

Jakarta Post 2011b 967 forestry firms under govt scrutiny. 2 February. http://www.thejakartapost. com/news/2011/02/02/967-forestry-firms-undergovt-scrutiny.html (23 October 2011).

Jakarta Post 2011c Greenomics alleges Aceh forest used as collateral in deal. 7 May. http://www. thejakartapost.com/news/2011/05/07/greenomicsalleges-aceh-forest-used-collateral-deal.html (23 October 2011).

Jiwan, N. 2010 Deforestation moratorium is not panacea? Jakarta Post, 1 July. http:// www.thejakartapost.com/news/2010/07/01/ deforestation-moratorium-not-panacea.html (23 October 2011).

Johnston, M. 2005a Syndromes of corruption: wealth, power and democracy. Cambridge University Press, Cambridge, UK.

Johnston, M. (ed.) 2005b Civil society and corruption: mobilizing for reform. University Press of America, Lanham, Maryland, USA.

Jurnal Nasional 2010 Menhut: konversi lahan adil bagi rakyat. 19 October. http://www.jurnas.com/ jurnas $/$ show $/$ breakingnews?page $=84$ \&rubrik=Ekon omi\&berita=37232_(23 October 2011).

Kanninen, M. 2010 REDD+ in Indonesia - research approaches, early findings, and preliminary results. Presented at the NORAD Civil Society Meeting. Bogor, Indonesia, 20-21 May 2010.

Karklins, R. 2005 The system makes me do it: corruption in post-communist societies. M.E. Sharpe, Armonk, NY.
Kolstad, I. and Wiig, A. 2009 Is transparency the key to reducing corruption in resource-rich countries? World Development 37: 521-532.

Komisi Pemberantasan Korupsi (KPK) 2008 Optimalizasi pelayanan publik - Public Services Optimized: Annual Report 2008. KPK, Jakarta, Indonesia.

Komisi Pemberantasan Korupsi (KPK) 2009 Panduan penanganan konflik kepentingan bagi penyelenggara negara. KPK, Jakarta, Indonesia.

Komisi Pemberantasan Korupsi (KPK) 2010a KPK fokus pada 4 sektor rawan korupsi (Press release). 2 March. http://www.kpk.go.id/modules/news/ article.php?storyid=1231 (23 October 2011).

Komisi Pemberantasan Korupsi (KPK) 2010b Paparan hasil kajian KPK tentang kehutanan (Press release). 3 December. http://www.kpk. go.id $/$ modules $/$ news $/$ article.php?storyid $=1726$ (23 October 2011).

Komisi Pemberantasan Korupsi (KPK) 2010c Matriks temuan dan saran perbaikan kajian sistem perencanaan dan pengelolaan kawasan hutan pada ditjen planologi kehutanan kementerian kehutanan Republik Indonesia. http://www.kpk. go.id/uploads/PDdownloads/matriks_temuan_ dan_saran_perbaikan_kajian_kehutanan.pdf (23 October 2011).

Kompas 2010a Posisi masyarakat adat harus jelas. 13 September. http://cetak.kompas.com/ $\mathrm{read} / 2010 / 09 / 13 / 04274580 /$ posisi.masyarakat. adat.harus.jelas (23 October 2011)

Kompas 2010b Penyumbang emisi gas rumah kaca terbesar. 1 October. http://sains.kompas.com/ $\mathrm{read} / 2010 / 10 / 01 / 06311126 /$ Penyumbang.Emisi. Gas.Rumah.Kaca.Terbesar (23 October 2011).

Kompas 2010c Izin pelepasan hutan lindung terhambat lagi. 19 November. http://cetak.kompas. $\mathrm{com} / \mathrm{read} / 2010 / 11 / 19 / 03461281 /$ izin.pelepasan. hutan.lindung..terhambat.lagi (23 October 2011).

Kompas 2010d Perlindungan hutan terancam. 24 November. http://cetak.kompas.com/ $\mathrm{read} / 2010 / 11 / 24 / 03401267 /$ perlindungan.hutan. terancam (23 October 2011).

Kompas 2010e Ada kelemahan sistemik. 4 December. http://nasional.kompas.com/ $\mathrm{read} / 2010 / 12 / 04 / 0250502 / A d a . K e l e m a h a n$. Sistemik (23 October 2011). 
Kompas $2010 \mathrm{f}$ Indonesia gets USD45 million to address climate change. 9 December. http://english. kompas.com/read/2010/12/09/1021042/Indonesia. Gets.USD45.Million.to.Address.Climate.Change-5 (23 October 2011).

Kompas $2010 \mathrm{~g}$ Pengusaha tanya lahan terdegradasi. 11 December. http://cetak.kompas.com/ $\mathrm{read} / 2010 / 12 / 11 / 04033777 /$ Pengusaha.Tanya. Lahan.Terdegradasi (23 October 2011).

Kontan 2010 Kemeneg BUMN akan restrukturisasi BUMN kehutanan. May 6. http://nasional.kontan. co.id/v2/read/1273134833/35932/KemenegBUMN-akan-Restrukturisasi-BUMN-Kehutanan(4 November 2011).

Lambsdorff, J.G. 2007 The institutional economics of corruption and reform: theory, evidence, and policy. Cambridge University Press, Cambridge, UK.

Lang, C. 2010a Corruption allegations cloud the Indonesia-Norway billion dollar deal. 21 September. http://www.redd-monitor. org/2010/09/21/corruption-allegations-cloud-theindonesia-norway-billion-dollar-deal

(23 October 2011)

Lang, C. 2010b Comments invited on Indonesia's Draft National REDD+ Strategy, 19 October. http://www.redd-monitor.org/2010/10/19/ comments-invited-on-indonesias-draft-nationalredd-strategy/ (23 October 2011).

Lang, C. 2010c Carbon Conservation gets into bed with Asia Pulp and Paper, one of Indonesia's biggest forest destroyers. 5 October. http:// www.redd-monitor.org/2010/10/05/carbonconservation-gets-into-bed-with-asia-pulp-andpaper-one-of-indonesias-biggest-forest-destroyers/ (23 October 2011).

Letter of Intent (LoI) 2010 Letter of Intent between the Government of Kingdom of Norway and the Government of the Republic of Indonesia on Cooperation on Reducing Greenhouse Gas Emission from Deforestation and Forest Degradation. 26 May. Oslo, Norway. http://www.dephut.go.id/files/LoI_Norwegia_ DirjenBPK_04062010.pdf (23 October 2011).

Lindstedt, C. and Naurin, D. 2010 Transparency is not enough: making transparency effective in reducing corruption. International Political Science Review 3: 301-322.
Macqueen, D. 2010 Review of funds which aim to protect tropical forests. International Institute for Environment and Development, Edinburgh, UK.

Madeira, E.M., Sills, E., Brockhaus, M., Verchot, L. and Kanninen, M. 2010 What is a REDD+ pilot? A preliminary typology based on early actions in Indonesia. CIFOR Info Brief No. 20. CIFOR, Bogor, Indonesia.

Medan Bisnis Daily 2009 Aceh logging moratorium has not made any progress. 17 September. http://www.medanbisnisdaily.com/news/ $\mathrm{read} / 2010 / 09 / 17 / 420 /$ moratorium_logging_di_ aceh_jalan_di_tempat/ (23 October 2011).

Ministry of Environment (MoE) 2010 Indonesia's second national communication under the United Nations Framework Convention on Climate Change (UNFCCC) (rev. 16 January 2010). Ministry of Environment, Government of Indonesia, Jakarta, Indonesia.

Ministry of Finance 2010 Pelengkap buku pegangan penyelenggaraan pemerintahan dan pembangunan daerah 2010 - sinergi pusat dan daerah dalam pelaksanaan desentralisasi fiskal. Ministry of Finance, Jakarta, Indonesia.

Ministry of Forestry (MoF) 2004 Pemantapan kawasan hutan melengkapi 5 target sukses Menteri Kehutanan 2004-2009. Press release S.662/II/PIK-1/2004. MoF, Jakarta, Indonesia. http://www.dephut.go.id/INFORMASI/ HUMAS/2004/662_04.htm (23 October 2011).

Ministry of Forestry (MoF) 2007 Road map revitalisasi industri kehutanan Indonesia. In-house Expert Working Group, Revitalisasi Industri Kehutanan. MoF, Jakarta, Indonesia.

Ministry of Forestry (MoF) 2009 National strategy on reducing emissions from deforestation and forest degradation in Indonesia: readiness phase. Draft (August). MoF, Jakarta, Indonesia.

Ministry of Forestry (MoF) 2010 Rencana aksi tindak lanjut fase I LOI Indonesia dengan Norwegia, 11 June. http://www.dephut.go.id/ files/LoI_Norwegia_DirjenBPK_11062010_0.pdf (23 October 2011).

Ministry of Home Affairs 2009 Daftar peraturan daerah dan keuputusan kepala daerah yang dibatalkan, data tahun 2002-2009. Ministry of Home Affairs, Jakarta, Indonesia. http://www. depdagri.go.id/media/documents/2010/03/05/d/a/ 
daftar_kepmen_pembatalan_perda_data_20022009.pdf (23 October 2011).

Morris, S.D. 2011 Forms of corruption. CESifo DICE Report 2/2011. http://www.ifo.de/DocDL/ dicereport211-forum2.pdf (23 October 2011).

Murdiyarso, D., Puntodewo, A., Widayati, A. and van Noordwijk, M. 2006 Determination of eligible lands for A/R CDM project activities and of priority districts for project development support in Indonesia. CIFOR, Bogor, Indonesia.

Noordwijk, M.V., Purnomo, H., Peskett, L.P. and Setiono, B. 2008 Reducing emissions from deforestation and forest degradation (REDD) in Indonesia: options and challenges for fair and efficient payment distribution mechanisms. ICRAF Working Paper No 81. World Agroforestry Centre, Bogor, Indonesia.

Nova, J 2010 Corruption for dinner, anyone? The carbon market scandal. 25 August. http:// joannenova.com.au/2010/08/corruption-fordinner-anyone-the-carbon-market-scandal/ (21 April 2011).

Occhiolini, M. 1990 Debt-for-nature swaps. Policy, research and external affairs. Working Paper. World Bank, Washington, DC.

Organisation for Economic Co-operation and Development (OECD) 2010 OECD transfer pricing guidelines for multinational enterprises and tax administrations. OECD, Paris.

Pirard, R. and Bille, R. 2010 Payments for environmental services (PES): a reality check (stories from Indonesia). IDDRI Analyses No. 03. Institut du développement durable et des relations internationales, Paris, France.

Purnomo, H., van Noordwijk, M., Peskett, L. and Setiono, B. 2007 Payment mechanisms, distribution and institutional arrangements. Indonesian Forest Climate Alliance (IFCA), Jakarta, Indonesia.

Pusat Pelaporan dan Analisis Transaksi Keuangan (PPATK) 2010 Striker bertambah, gol diharapkan menjadi lebih banyak. 10 November. (14 March 2011).

Rainforest Foundation Norway 2010 Norway and Indonesia agree a US\$ 1 billion partnership on forests: This could be an important step towards the preservation of Indonesia's rainforest. Press release. 26 May. http://www.redd-monitor. org/2010/05/27/norway-and-indonesia-sign-us1billion-forest-deal/\#rfns (4 November 2011).

Reed, P. 2011 REDD+ and the Indigenous Question: A Case Study from Ecuador. Forests 2: 525-549.

Republik Indonesia 2009 Nota keuangan dan anggaran pendapatan dan belanja negara tahun anggaran 2009. Republik Indonesia, Jakarta, Indonesia.

Republika 2009 Mega and SBY did not stop logging. 17 June. http://rol.republika.co.id/berita/56784/ Mega_dan_SBY_Tak_Hentikan_Penebangan_ Hutan (23 October 2011).

Republika 2010 Indonesia galang satu suara ASEAN untuk iklim. 11 December. http:// www.republika.co.id/berita/breaking-news/ lingkungan/10/12/11/151690-indonesia-galangsatu-suara-asean-untuk-iklim (23 October 2011).

Republika 2010b KPK Tahan Mantan Staf Ahli Menteri Kehutanan. 22 October. http:// www.republika.co.id/berita/breaking-news/ hukum/10/10/22/141775-kpk-tahan-mantan-stafahli-menteri-kehutanan (4 November 2011)

Resosudarmo, I.A.P., Barr, C., Dermawan, A. and McCarthy, J. 2006 Fiscal balancing and the redistribution of forest revenues. In: Barr, C., Resosudarmo, I. A. P., Dermawan, A. and McCarthy, J. (eds) Decentralization of forest administration in Indonesia: implications for forest sustainability, economic development and community livelihoods, 58-86. CIFOR, Bogor, Indonesia.

Reuters 2008 Factbox: forest preservation-carbon credit schemes in Asia. 29 October. http://www. reuters.com/article/idUSTRE49S0NA20081029 (23 October 2011).

Sarre, R., Das, D.K. and Albrecht, H.J. (eds) 2005 Policing corruption: international perspectives. Lexington books, Lanham, MD, USA.

Sato, Y. 2005 Bank restructuring and financial institution reform in Indonesia. The Developing Economies 43: 91-120.

Schneider, L. 2007 Is the CDM fulfilling its environmental and sustainable development objectives? An evaluation of the CDM and options for improvement. Report prepared for WWF, 5 November. Oko-Institut, Berlin, Germany.

Slette, J. and Wiyono, I.E. 2011 Indonesia forest moratorium 2011. GAIN Report No. ID 1127. 
June 8. US Department of Agriculture Foreign Agricultural Service, Jakarta, Indonesia.

Stern, N. 2006 The Stern review: the economics of climate change. Cambridge University Press, Cambridge, UK.

Subarudi and Dwiprabowo, H. 2007 Otonomi daerah bidang kehutanan: implementasi dan tantangan kebijakan perimbangan keuangan. CIFOR, Bogor, Indonesia.

Sunderlin, W. 2007 Poverty, rights and tenure on forest lands: the problem, and priority actions to achieving solutions. Background paper for the conference 'Towards achieving a new global forest agenda'. Rights and Resources Institute, Washington, D.C.

Sunderlin, W.D., Larson, A.M. and Cronkleton, P. 2009 Forest tenure rights and REDD. In: Angelsen, A. (ed.) Realising REDD+: national strategy and policy options. CIFOR, Bogor, Indonesia.

Suyanto, S., Leimona, B., Permana, R. P., and Chandler, F. J. C. 2005 Review of the development of environmental services market in Indonesia. ICRAF, Bogor, Indonesia.

Syngellakis, K. 2011 Voluntary carbon market opportunities for Pacific countries.. Presentation at workshop for policy and decision makers on the implementation of CDM. Suva, Fiji, 24 January.

Tanzi, V. 1998 Corruption and the budget: problem and solutions. In: Jain, A.K. (ed.) Economics of corruption. Kluwer Academic Publishers, Norwell, MA, USA.

Tarling, N. (ed.) 2005 Corruption and good governance in Asia. Routledge, London and New York.

Tempo 2007 Paska moratorium, pencurian kayu di Aceh turun. 7 December.

Tempo 201110 besar provinsi yang perdanya dibatalkan. 26 January. http://www. tempointeraktif.com/hg/hukum/2011/01/28/ brk,20110128-309675, id.html (23 October 2011).

Terra Global Capital 2010 An Integrated REDD Offset Program (IREDD) for nesting projects under jurisdictional accounting. Developed for the California Governors' Climate and Forest Task Force. Terra Global Capital, San Francisco, CA, USA.
Thapa, B. 2000 The relationship between debtfor-nature swaps and protected area tourism: a plausible strategy for developing countries. In: McCool, S.F., Cole, D.N., Borrie, W.T. and O'Loughlin, J. (eds.) Wilderness science in a time of change conference. Volume 2: Wilderness within the context of larger systems. Missoula, MT, 23-27 May 1999. Proceedings RMRS-P-15VOL-2. Ogden, UT, 268-272. US Department of Agriculture, Forest Service, Rocky Mountain Research Station.

The Nature Conservancy and Baker \& McKenzie 2010 A nested approach to REDD+: structuring effective and transparent incentive mechanisms for REDD+ implementation at multiple scales. Forest Carbon Portal. 1 June. http:// www.forestcarbonportal.com/resource/nestedapproach-redd-structuring-effective-andtransparent-incentive-mechanisms-redd-implem (23 October 2011).

Transparency International 2010 Corruption perception index 2010 results. http://www. transparency.org/policy_research/surveys_indices/ cpi/2010/results (23 October 2011).

Transparency International 2011 The global corruption report: climate change. Transparency International, Berlin, Germany.

United Nations Development Programme (UNDP) 2010 Staying on track: tackling corruption risks in climate change. UNDP, New York.

United Nations Framework Convention on Climate Change (UNFCCC) 1998 The Kyoto Protocol to The United Nations Framework Convention on Climate Change. http://unfccc.int/resource/docs/ convkp/kpeng.pdf (23 October 2011).

United Nations Framework Convention on Climate Change (UNFCCC) 2007 The Bali Action Plan. 2/cp13. UNFCCC, Bali, Indonesia. http://unfccc. int/files/meetings/cop_13/application/pdf/cp_bali_ action.pdf (23 October 2011).

United Nations Framework Convention on Climate Change (UNFCCC) 2009 Methodological guidance for activities relating to reducing emissions from deforestation and forest degradation and the role of conservation, sustainable management of forests and enhancement of forest carbon stocks in developing countries. 4/ cp15. UNFCCC, Copenhagen, Denmark http:// 
unfccc.int/resource/docs/2009/cop15/eng/11a01. pdf\#page $=11$ (23 October 2011).

United Nations Framework Convention on Climate Change (UNFCCC) 2010 Report of the Conference of the Parties serving as the meeting of the Parties to the Kyoto Protocol on its sixth session, held in Cancun from 29 November to 10 December 2010. UNFCCC, Cancun, Mexico. http://unfccc.int/resource/docs/2010/cmp6/ eng/12a02.pdf (23 October 2011).

United Nations Office on Drugs and Crime (UNODC) 2006 Assessment of justice system integrity and capacity in two Indonesian provinces. Technical assessment report. UNODC, Vienna, Austria, and Jakarta, Indonesia. http://www. unodc.org/documents/eastasiaandpacific// Publications/Projects/indonesia/e-assessment.pdf (23 October 2011).

United Nations Office on Drugs and Crime (UNODC) and Center for the Study of Democracy (CSD). 2005 Workshop on measuring and monitoring corruption and anti-corruption. UNODC and CSD. Sofia, Bulgaria http://www. unodc.org/pdf/corruption/publication_sofia_ workshop.pdf (23 October 2011).

United States Department of State 20102010 International narcotics control strategy report (INCSR) - volume II: money laundering and financial crimes country database - Indonesia through Mongolia. Bureau of International Narcotics and Law Enforcement Affairs, Washington, DC.

Verchot, L.V., Petkova, E., Obidzinski, K., Atmadja, S., Yuliani, E.L., Dermawan, A., Murdiyarso, D. and Amira, S. 2010 Reducing forestry emissions in Indonesia. CIFOR, Bogor, Indonesia.

Victor, D. and Wara, M. 2008 A realistic policy on international carbon offsets. Program on Energy and Sustainable Development Working Paper \#74. Stanford Unicersity, Stanford,USA.

Wahana Lingkungan Hidup Indonesia (Walhi) 2011 Illegal logging corruption in forestry sector. UNODC Anti-Corruption Talk Series with Special Focus on Forest. www.unodc.org/ documents/eastasiaandpacific/2011/02/1sttalk-series/presentation._Illegal_Logging_and_ Corruption_in_Forestry_Sector_WALHI.pdf (23 October 2011).
Wara, M. 2006 Measuring the Clean Development Mechanism's performance and potential. Working Paper \#56. Stanford University, CA, USA. http:// iis-db.stanford.edu/pubs/21211/Wara_CDM.pdf (23 October 2011).

Waspada Online 2007 Meski moratorium, masih terjadi penebangan hutan. 22 August. http://www. waspada.co.id/index.php?option=com_content\&view $=$ article $\&$ id $=2280$ : meski-moratorium-masih-terjadipenebangan-hutan\&catid $=13$ : aceh \&Itemid $=26$ (23 October 2011).

Widhiyanto, F. 2011 Mereka yang 'basah' oleh minyak sawit. Investor, February. pp. 44-47.

Wijayanto 2009 Memahami korupsi. In: Wijayanto and Zachrie, R. (eds) Korupsi mengorupsi Indonesia: sebab, akibat dan prospek pemberantasan. Gramedia, Pustaka Utama, Jakarta, Indonesia.

World Bank 1997 Helping countries combat corruption: the role of the World Bank. World Bank, Washington DC.

World Bank 2008 An innovative forest project in Indonesia creates alternatives for illegal loggers. http://web.worldbank.org/WBSITE/EXTERNAL/ COUNTRIES/EASTASIAPACIFICEXT/INDONE SIAEXTN/0,,contentMDK:21576161 pagePK:1497 618 piPK:217854 -theSitePK:226309,00.html (23 October 2011).

World Bank 2010 The worldwide governance indicators: methodology and analytical issues. World Bank Policy Research Working Paper No. 5430.

World Resources Institute (WRI). 2010 Summary of developed country fast-start climate finance pledges. http://pdf.wri.org/climate_finance_ pledges_2010-10-02.pdf (23 October 2011).

\section{Interviews}

Interview with private sector staff. 2011, 8 January. Association for Forest Concession Holders (APHI; Asosiasi Pengusaha Hutan Indonesia).

Interview with Bappenas officials. 2011, 5 January. Directorate of Forestry and Water Resources Conservation; National Planning Development Agency, Bappenas Office, Jakarta, Indonesia.

Interview with KPK official. 2011, 14 January. KPK Office, Jakarta, Indonesia 
Interview with Ministry of Forestry official. 2011, 6 January. Directorate General of Forest Production Development, Ministry of Forestry, Manggala Wanabhakti, Jakarta, Indonesia.

Interview with Ministry of Forestry official. 2011, 7 January. Directorate General of Forest Production Development, Ministry of Forestry, Manggala Wanabhakti, Jakarta, Indonesia.

Interview with Ministry of Forestry official. 2011, 8 April. Directorate General of Forest Production Development, Ministry of Forestry, Manggala Wanabhakti, Jakarta, Indonesia.

\section{Laws and regulations}

Bank Indonesia Regulation No. 3/10/PBI/2001 on the Implementation of Know-YourCustomer Principles.

Bank Indonesia Regulation No. 11/28/PBI/2009 on the Implementation of Anti-Money Laundering and Terrorism Financing Prevention of Commercial Banks.

Bank Indonesia Circular No. 11/31/DPNP/2009 on Standard Guidelines for Implementation of AntiMoney Laundering and Combating the Financing of Terrorism Programme for Commercial Banks.

Bank Indonesia Regulation No. 12/3/PBI/2010 on the Application of Anti-Money Laundering and Prevention of Terrorism Financing for Bank Foreign Exchange Traders, 1 March. http://www. bi.go.id/web/en/Peraturan/Moneter/pbi_120310. htm (22 October 2011).

Directorate General of Forest Production Development. 2010 Peraturan Direktur Jenderal Bina Produksi Kehutanan No. 3/VI-Set/2010 mengenai Pedoman Pengukuran, Pelaporan dan Verifikasi Kegiatan Pemanfaatan Hutan Lestari pada Areal Kerja Izin Usaha Pemanfaatan Hasil Hutan Kayu. Kementerian Kehutanan, Jakarta, Indonesia.

Government Regulation No. 44/2004 on Forest Area PlanningGovernment Regulation No. 55/2005 on Balancing Fund.

Government Regulation No. 6/2007 on Forest Planning, Management and Use.
Governor of Aceh Instruction No. 5/2007 on Logging Moratorium on Natural Forests

Law No. 41/1999 on Forestry.

Law No. 31/1999 on Eradicating Corruption.

Law No. 20/2001 on Revision of Law No. 31/1999 on Eradicating Corruption.

Law No. 15/2002 on Money Laundering.

Law No. 30/2002 on the Establishment of Corruption Eradication Commission.

Law No. 25/2003 on Revision of Law No. 15/2002 on Money Laundering.

Law No. 33/2004 on Fiscal Balance between Central Government and Local Government.

Law No. 7/2006 on the Ratification of United Nations Convention Against Corruption 2003.

Law No. 26/2007 on Spatial Planning.

Law No. 14/2008 on Access to Information .

Law No. 8/2010 on Preventing and Eradicating Money Laundering.

Majelis Permusyawaratan Rakyat (MPR). 1998 Ketetapan Majelis Permusyawaratan Rakyat Republik Indonesia Nomor XI/MPR/1998 tentang Penyelenggara Negara yang Bersih dan Bebas Korupsi, Kolusi, dan Nepotisme. Jakarta. 13 November 1998.

Majelis Permusyawaratan rakyat (MPR). 2001 Ketetapan Majelis Permusyawaratan Rakyat Republik Indonesia Nomor VIII/MPR/2001 tentang Rekomendasi Arah Kebijakan Pemberantasan dan Pencegahan Korupsi, Kolusi, dan Nepotisme. Jakarta. 9 November 2001.

Ministry of Forestry Regulation No. 10.1/KptsII/2000 on Guidance for Granting Timber Plantation Permits.

Ministry of Forestry Regulation No. 21/Kpts-II/2001 on Criteria and Standards for Licensing Timber Plantations in Production Forests.

Ministry of Forestry Decree SK.32/Kpts-II/2001 on Standards and Criteria for Forest Area Affirmation.

Ministry of Forestry Decree P.30/Menhut-II/2009 on Implementation Procedures for Reducing Emission From Deforestation and Forest Degradation (REDD+).

Ministry of Forestry Decree P.36/Menhut-II/2009 on Procedures for Licensing of Commercial Use of Carbon and Storage in Production and Protection Forests. 
Ministry of Forestry Regulation P.18/MenhutII/2007 on Technical Guidelines for Collecting and Payment of Forest Resources Provision and Reforestation Fund.

Ministry of Forestry Regulation P.36/MenhutII/2009 on Procedures for Licensing for Carbon Sink and Sequestration on Production and Protection Forests.

Ministry of Forestry Regulation P.50/MenhutII/2009 on Affirmation on Forest Area Function and Status.

Ministry of Forestry Regulation P.14/MenhutII/2011 on Timber Use Permits.

Presidential Decree No. 4/2009 on Coordination Agency for National Spatial Planning.
Presidential Decree No. 19/2010 on REDD+ Task Force.

Pusat Pelaporan dan Analisis Transaksi Keuangan (PPATK) Decree No. Kep-2B/1.02/PPATK04/06 on Guidelines on Providing Information on Money Laundering in Forestry and Biodiversity Conservation Sector.

\section{Court rulings}

Court Decision No. 04/PID.B/2006/PN.JPR

Court Decision No. 6/PID/TPK/2008/PN.JKT.PST

Supreme Court Decision No. 380 K/Pid.Sus/2007 


\section{Annex 1. REDD+ pilot project in Aceh}

Information in this annex was derived from the presentation by Fauna \& Flora International in 2009: REDD pilot projects in West Kalimantan, Indonesia, and from Provincial Government of Nanggroe Aceh Darussalam (Aceh) 2009 Reducing carbon emissions from deforestation in the Ulu Masen ecosystem, Aceh, Indonesia (A triple-benefit project design note for CCBA Audit). Aceh, Indonesia. http://www. climate-standards.org/projects/files/Final_Ulu_ Masen_CCBA_project_design_note_Dec29.pdf (23 October 2011).

\section{Fact sheet}

Name of project:

Reducing Carbon Emissions from Deforestation in the Ulu Masen Ecosystem, Aceh, Indonesia

Start year: REDD+ concept developed in early 2007 by the government of Aceh and Carbon Conservation with technical assistance from Fauna $\&$ Flora International (FFI). REDD+ project to achieve CCBA certification. Detailed timeline of the project based on the project document is as follows.

Phase 1: Information gathering, technology and skills transfer and development of project structures, institutional framework and financing (6 months, July-December 2007).

Phase 2: Develop benefit-sharing mechanisms; implement planning processes, implement legislative and regulatory changes, set up a system for forest and carbon stock monitoring, preparation for community forestry, reforestation and agroforestry projects (18 months, July 2007 to December 2008).

Phase 3: Ongoing forest and carbon monitoring; promotion of sustainable community forest management, forest product value-adding, reforestation and community agroforestry; monitoring 'virtual' carbon funding (ODA funds) disbursed through incentive mechanisms (5 years, January 2008 to December 2012). Financed through the sale of voluntary verified emission reductions (VERs), or earlyaction credits.

Phase 4: Transfer to 2nd commitment period REDD+ credits or appropriate outcome of UNFCCC negotiations post-Kyoto commercial market mechanisms (Years 4 and 5).

Location: The project is located in the 4 northernmost districts or kabupaten of Aceh Province: Aceh Besar, Aceh Jaya, Aceh Barat and Pidie. The Ulu Masen ecosystem is situated between $4^{\circ} 20^{\prime} \mathrm{N}$ and $53^{\circ} 0^{\prime} \mathrm{N}$ between $95^{\circ} 20^{\prime} \mathrm{E}$ and $96^{\circ} 30^{\prime} \mathrm{E}$.

Size (ha): This project will focus on contiguous forests within the Ulu Masen ecosystem, a 750000 ha block of forest.

Population (number, indigenous-not): Approximately 130000 indigenous people of Aceh live in communities adjacent to forest areas of the Ulu Masen ecosystem. They live in 61 mukim surrounding the Ulu Masen ecosystem.

\section{Legal status and regulations under which registered:} Some related regulations form the basis of the project:

1. The government of Indonesia's new legislation on forest planning, management and use (Government Regulation PP.6/2007) provides a key legal basis for the implementation of this project. This regulation authorises provincial and district governments to issue licences (Izin Usaha Pemanfaatan Jasa Lingkungan; Permit for Ecological Service Use) for storing and absorbing carbon in both production and protection forests.

2. The Special Autonomy Law for the Province of Aceh, passed in 2006 following the cessation of the armed conflict between GAM and the government of Indonesia and the holding of free elections in Aceh, provides a further important legal basis for the retention and equitable sharing of funds generated through REDD+ carbon financing within the province. 
The project comes under the umbrella of two main national regulations on REDD+ issued in 2009:

1. Ministry of Forestry Decree P.30/MenhutII/2009 on Implementation Procedures for Reducing Emissions from Deforestation and Forest Degradation (REDD+).

2. Ministry of Forestry Decree P.36/MenhutII/2009 on Licensing Procedures for Commercial Use of Carbon and Storage in Production and Protected Forests

\section{Project proponents (organisations involved in one} way or another): The proposal has been submitted for review to the National Working Group on Climate and Forests as a pilot project for reducing emissions from deforestation and degradation (REDD+). The project is supported by a partnership of non-governmental and civil society organisations (NGOs/CSOs) led by Fauna \& Flora International (FFI). Carbon Conservation Pty Ltd is the lead private company assisting with project design, development, start-up and carbon finance.

Investors: Carbon Conservation Ltd

\section{Financiers (local banks, national banks,} government, etc.) Project involves Aceh government, the Carbon Conservation of Australia, Merrill Lynch and international non-profit NGO Fauna \& Flora International. Merrill Lynch has signed a multimillion dollar agreement to buy voluntary carbon credits in a deal running from 2008 to 2013.

The project is closely associated with, and builds on, the work of the World Bank Multi-Donor Fund's Aceh Environment and Forest Project (AFEP), which called for, amongst other tasks, development of sustainable ecosystem service finance (including carbon credits) to be developed for Aceh.

Stated objectives: The project estimates proposed activities will reduce deforestation in the area by $85 \%$ and 3369848 tonnes of $\mathrm{CO}_{2}$ emissions can be avoided each year. The project proponents can, with adequate carbon finance, institute measures that will reduce legal and illegal deforestation, promote reforestation and foster sustainable community forest management. Carbon-finance funds will be established to offset all, or most, of the opportunity costs of avoiding deforestation as well as support project activities and operations. A substantial portion of carbon finance will be deposited into these funds and will directly benefit local communities and forest guardians. By preventing deforestation, project proponents will help Aceh achieve a sustainable future that also preserves critical and highly threatened habitat for biodiversity and develop a sustainable community model for the use and conservation of forest.

Other stated facts: The net carbon emission reductions from the project are conservatively estimated to be 27546438 tonnes over 30 years.

Under the baseline assumptions at the end of 30 years there would be 108364096 tonnes of carbon. Under the project scenario, where $85 \%$ of all deforestation is stopped, there would be 135910534 tonnes of carbon. Thus, the project expects to generate 27546438 tonnes of avoided carbon credits over 30 years (the difference between the baseline scenario and the project scenario). This is equal to $101095427 \mathrm{CO}_{2}$ credits, using (22/6) to convert from carbon to carbon dioxide. Assuming linear deforestation and avoided deforestation, this equates to 3369848 tonnes of $\mathrm{CO}_{2}$ avoided (VERs) per year.

At the current market price of US $\$ 5$, the credits from the Ulu Masen project are forecast to be valued at approximately US\$16.5 million each year.

In the business community, Ulu Masen is known as the world's first commercially financed REDD+ project, where Bank of America Merrill Lynch purchased carbon credits from $7690 \mathrm{~km}^{2}$ of protected forest (Jakarta Post 2010 Carbon credits for Aceh forest. 1 June. http://www.thejakartapost.com/ news/2010/06/01/carbon-credits-aceh-forest.html. 4 November 2011). 


\section{Annex 2. REDD+ pilot project in West Kalimantan}

\section{Fact sheet}

Flora \& Fauna International received an AusAID grant to develop a concept for creating financial incentives to protect High Conservation Value Forests (HCVFs) threatened by conversion to oil palm across West Kalimantan. They are in the preparation stages of a project to pilot the reduced emissions from deforestation and degradation (REDD+) mechanism on land owned by oil palm concessionaires. This initiative will coordinate closely with FFI's existing REDD+ collaboration with Australian investment bank Macquarie within the voluntary carbon market. As stated by FFI, the project will involve detailed carbon and biodiversity mapping, intensive consultation with communities and engagement with local government decisionmakers in order to design the most effective REDD+ project possible (FFI 2010).

The project in West Kalimantan is part of an agreement between FFI and Australia's Macquarie Group to invest in 6 REDD+ projects globally, 3 of them in Indonesia. Two are in West Kalimantan, for which MoUs have been signed with the local government, and the third is in Papua Province. The other 3 projects are in Cambodia, Liberia and Ecuador (Reuters 2008).

The project title is 'Conservation of the Upper Kapuas Lakes System, Kapuas Hulu District, West Kalimantan'. Proposed project activities are as follows. (1) For conversion forest areas: reclassification of conversion forest areas to protection forest or limited production forest, mapping of customary forest, development of multistakeholder forest management units, development of community forest management, capacity building and sustainable financing, development of performance-based alternative livelihood programme, development of local benefit-sharing mechanism. (2) For forest on non-state land (APL): mapping of customary forest, development of community institutions, development of community forest management, capacity building and sustainable financing, development of performance-based alternative livelihood programme, development of local benefit-sharing mechanism.

\section{The current stage of this project: FFI and}

Macquarie are preparing and approaching the Ministry of Forestry to obtain an IUPHH restorasi ekosistem (HPH RE) permit as the legal framework of the REDD+ project in West Kalimantan. The Project Design Document is scheduled to be ready at the end of 2010 .

Name of project: Conservation of Upper Kapuas Lakes System, Kabupaten Kapuas Hulu, West Kalimantan

Start year: FFI has been working since 2008 in the Kapuas Hulu and Ketapang District as part of the $\mathrm{REDD}+$ project preparation.

Location: Kapuas Hulu District and Ketapang District, West Kalimantan Province, Indonesia

Size (ha); Kapuas Hulu District: 57000 ha; Ketapang District: 157000 ha (from secondary sources as the project design document is not yet available). Other information mentioned that, in West Kalimantan, the project will cover 44000 ha of peatlands.

\section{Population (number, indigenous or not):}

Unknown; no information about the number but the community involved in the REDD+ area seem to be indigenous people of West Kalimantan, Dayak in Kapuas Hulu and Malay in Ketapang District.

\section{Legal status and regulations under which registered:} FFI is in the process of obtaining an IUPHH Restorasi Ekosistem permit from the Ministry of Forestry; however, based on an FFI presentation at CIFOR in 2009, some regulations appear to form the significant policy framework:

1. Ministry of Forestry Decree P.30/MenhutII/2009 on Implementation Procedures for Reducing Emissions from Deforestation and Forest Degradation (REDD+) (as the basic REDD+ legal framework)

2. Ministry of Forestry Decree P. 36/MenhutII/2009 on Licensing Procedures for Commercial Use of Carbon and Storage in Production and Protected Forests) 
- REDD+ project proponents are national companies, state companies or cooperatives (international partners may include international investors and NGOs)

- REDD+ project holders must have clear tenure (IUPHHK-HA, IUPHHK-RE, IUPHHKHT, Hutan Desa, Hutan Adat, Hutan Kemasyarakatan)

- REDD+ project holders have to obtain an IUPJL (environmental services payment licence)

- REDD+ project holders have to obtain a REDD+ business licence (IU-PAN)

\section{Project proponents (organisations involved in one} way or another): FFI, PT Macquarie Capital Securities Indonesia. FFI is also working with local NGOs, including Perkumpulan Kaban, Yayasan Riak Bumi in Kapuas Hulu District and Yayasan Diantama in Ketapang District.

Investors: Macquarie Bank

Financiers (local banks, national banks, government, etc.): Macquarie Bank and FFI

Stated objectives: FFI has stated the following general objectives for the REDD+ project:

1. Reduce emissions from forest conversion in West Kalimantan in Ketapang and Kapuas Hulu Districts

2. Identify and secure high conservation value forests

3. Encourage the palm oil industry to operate with the lowest possible impact on biodiversity

4. Secure economic benefits for local communities to protect high conservation value forests

Other stated facts: According to FFI, the proposed project activities are:

1. For conversion forest areas: reclassification of conversion forest areas to protection forest or limited production forest, mapping of customary forest, development of multi-stakeholder forest management units, development of community forest management, capacity building and sustainable financing, development of performance-based alternative livelihood programme, development of local benefitsharing mechanism.

2. For forest on non-state land (APL): mapping of customary forest, development of community institutions, development of community forest management, capacity building and sustainable financing, development of performance-based alternative livelihood programme, development of local benefit-sharing mechanism.

Overlapping land tenure: Overlapping land tenure in the proposed REDD+ site is one of the main challenges for the project. Most of the proposed location for the REDD+ project overlaps with a forest concession $(\mathrm{HPH})$ and palm oil plantation permit.

FFI identified the following threats to the REDD+ project area:

1. Illegal logging

2. Unsustainable logging by forest concessionaire ( $\mathrm{HPH})$

3. Agricultural encroachment (rubber and rice)

4. Forest conversion to oil palm/pulp and paper

5. Forest fire

Based on a presentation by FFI, the project preparation included some activities related to social aspects and public consultation using Participatory Rural Appraisal (PRA) and Rapid Rural Appraisal (RRA) and initial REDD+ public awareness in 10 surrounding villages. Below are some of the findings.

Key findings: Coastal Malay communities claim no forest tenure; forest dependency is limited to a few families dependent on illegal logging. Forests are subject to small-scale conversion to swamp rice and rubber gardens. Communities offer in-principle support for a REDD+ scheme that reduces the need for illegal logging and forest conversion by providing incentives for community-based forest protection and finance for alternative livelihoods.

Initial public consultation with all relevant stakeholders (community representatives, NGOs and relevant district and provincial government agencies), which will be followed by an ongoing consultation process throughout the project cycle.

Review of the legal and institutional framework for carbon finance distribution mechanisms. Decree 36 (Permenhut) mandates profit sharing with local communities and government.

Monitoring socio-economic indicators in collaboration with CIFOR (full socio-economic baseline survey) and monitoring distribution of performance-based REDD+ payments. 

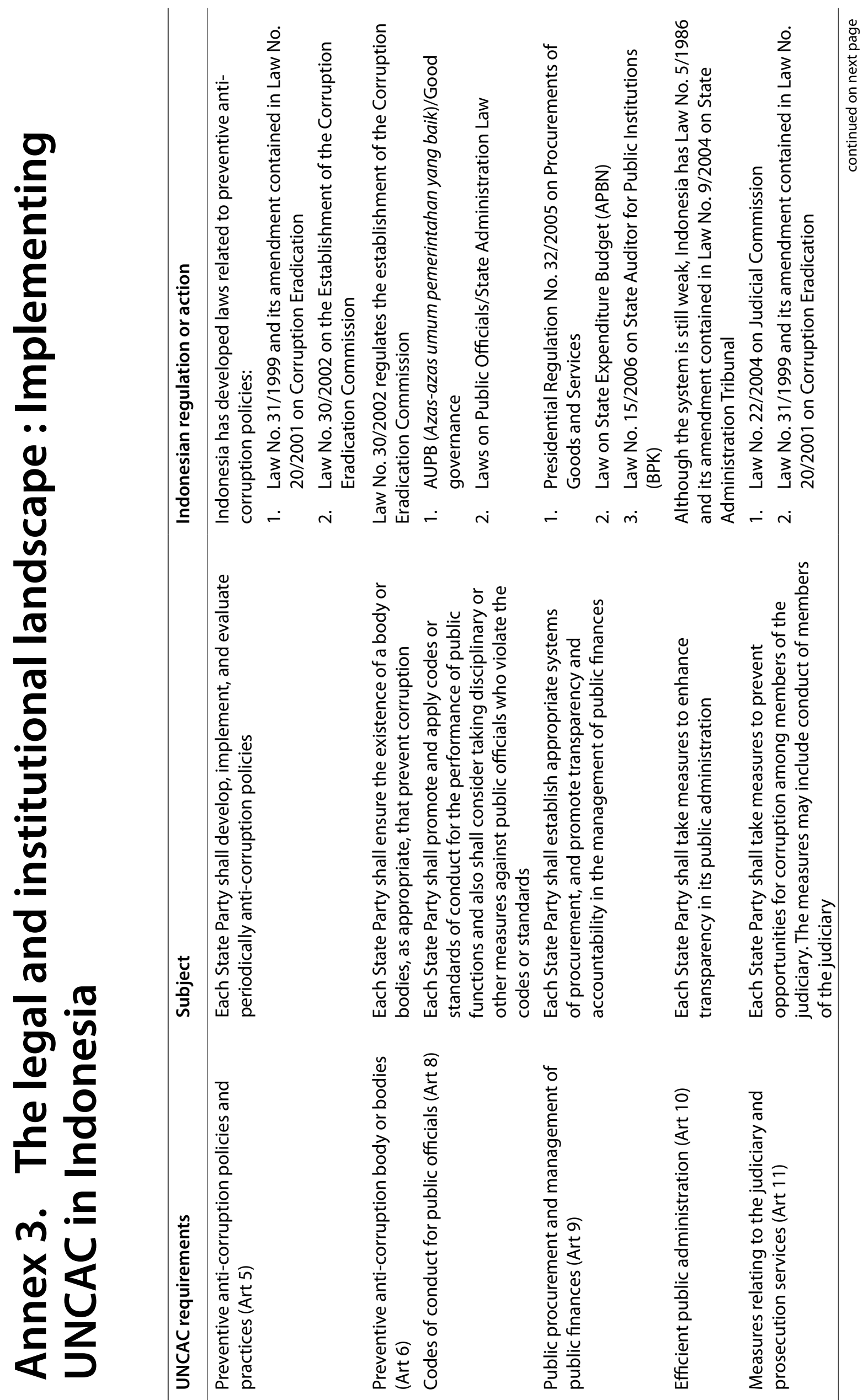


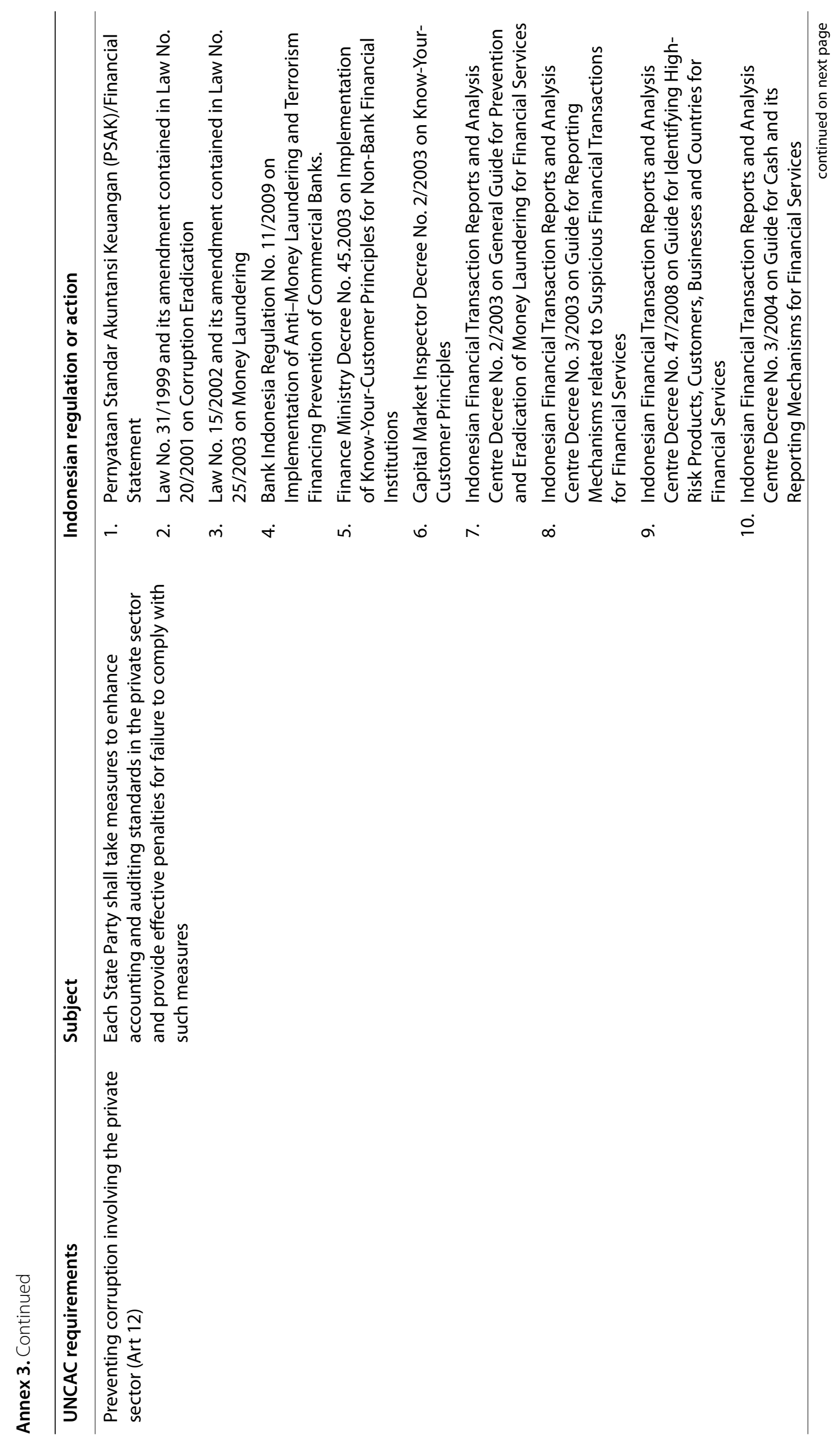




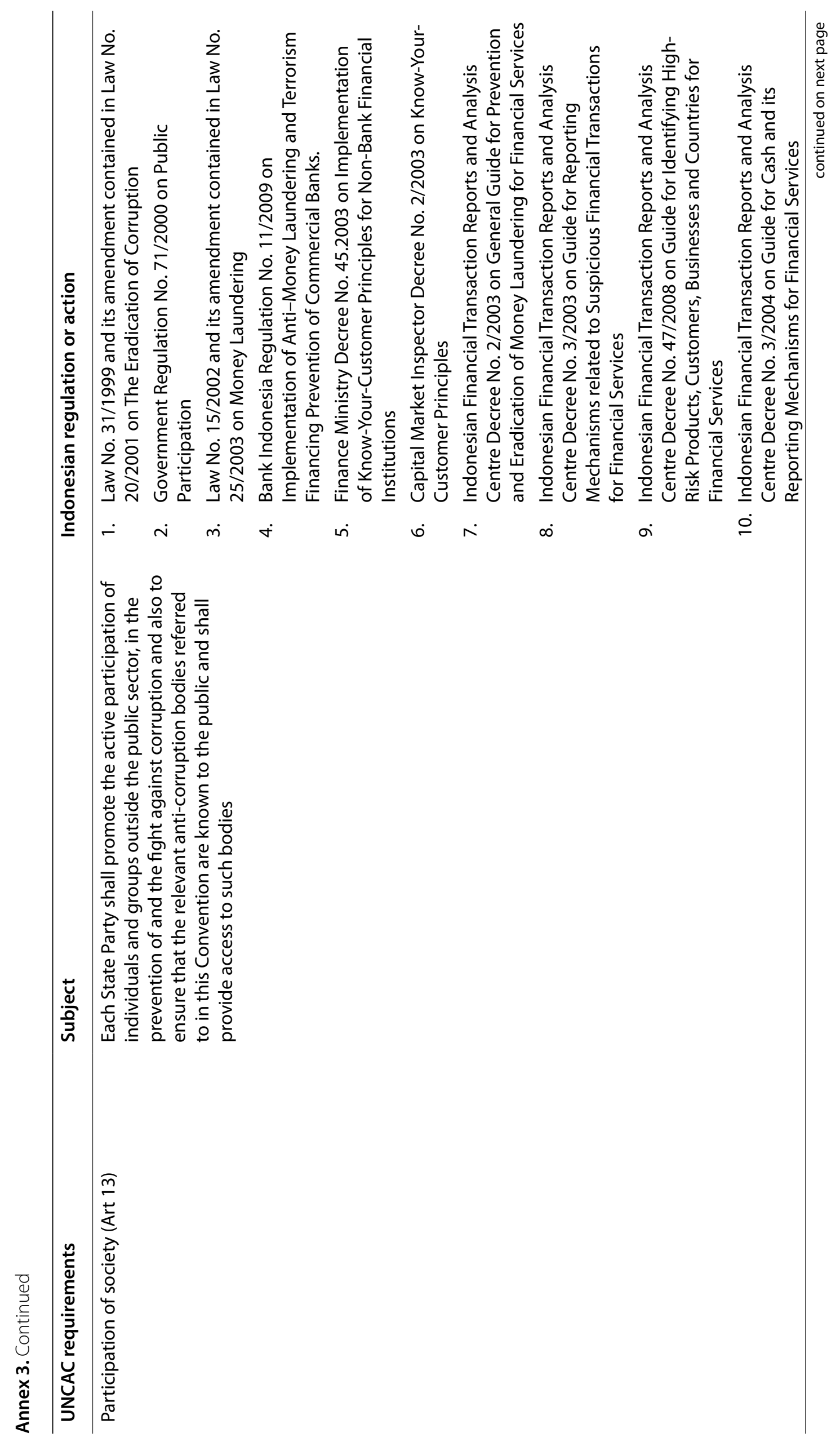




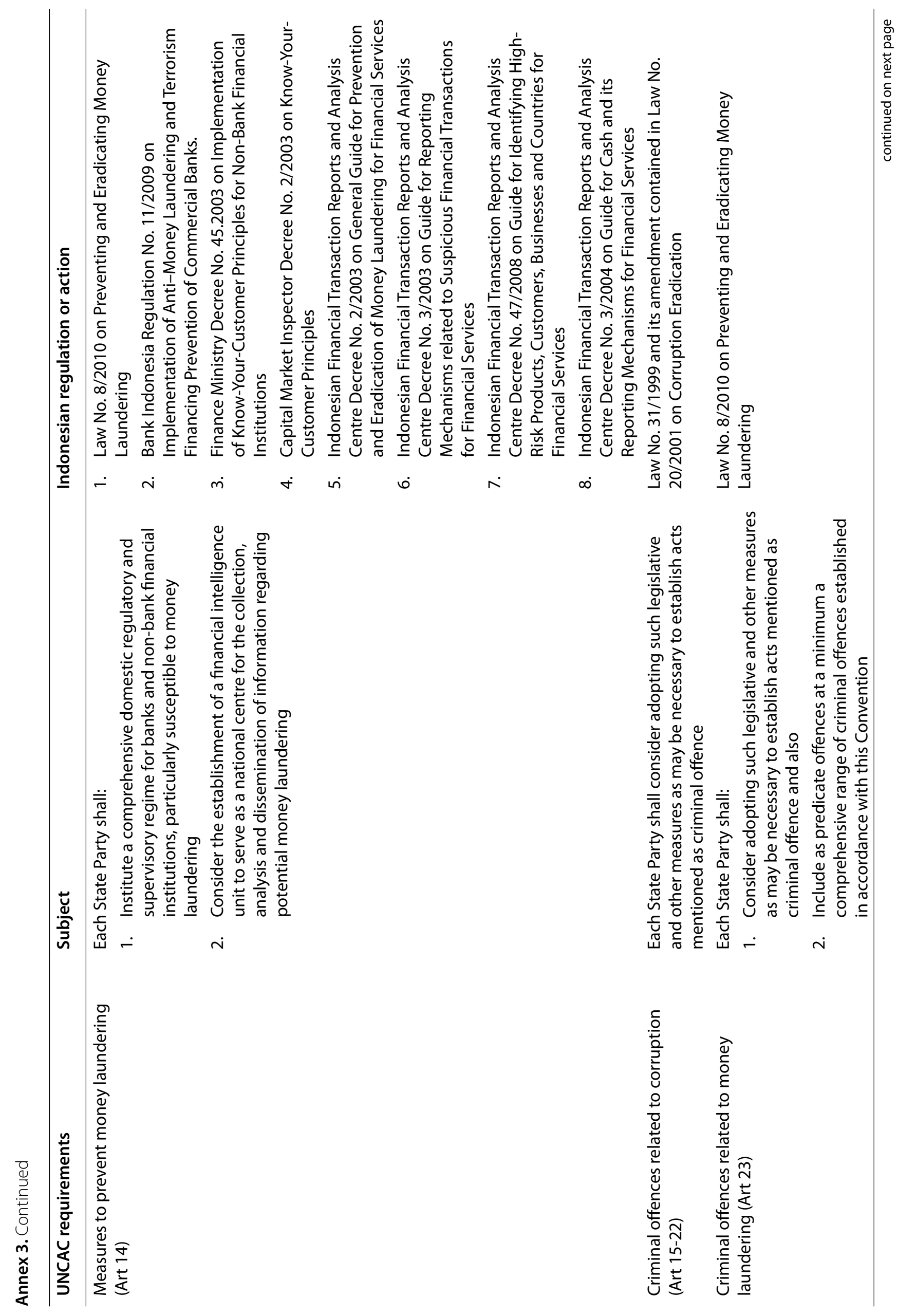




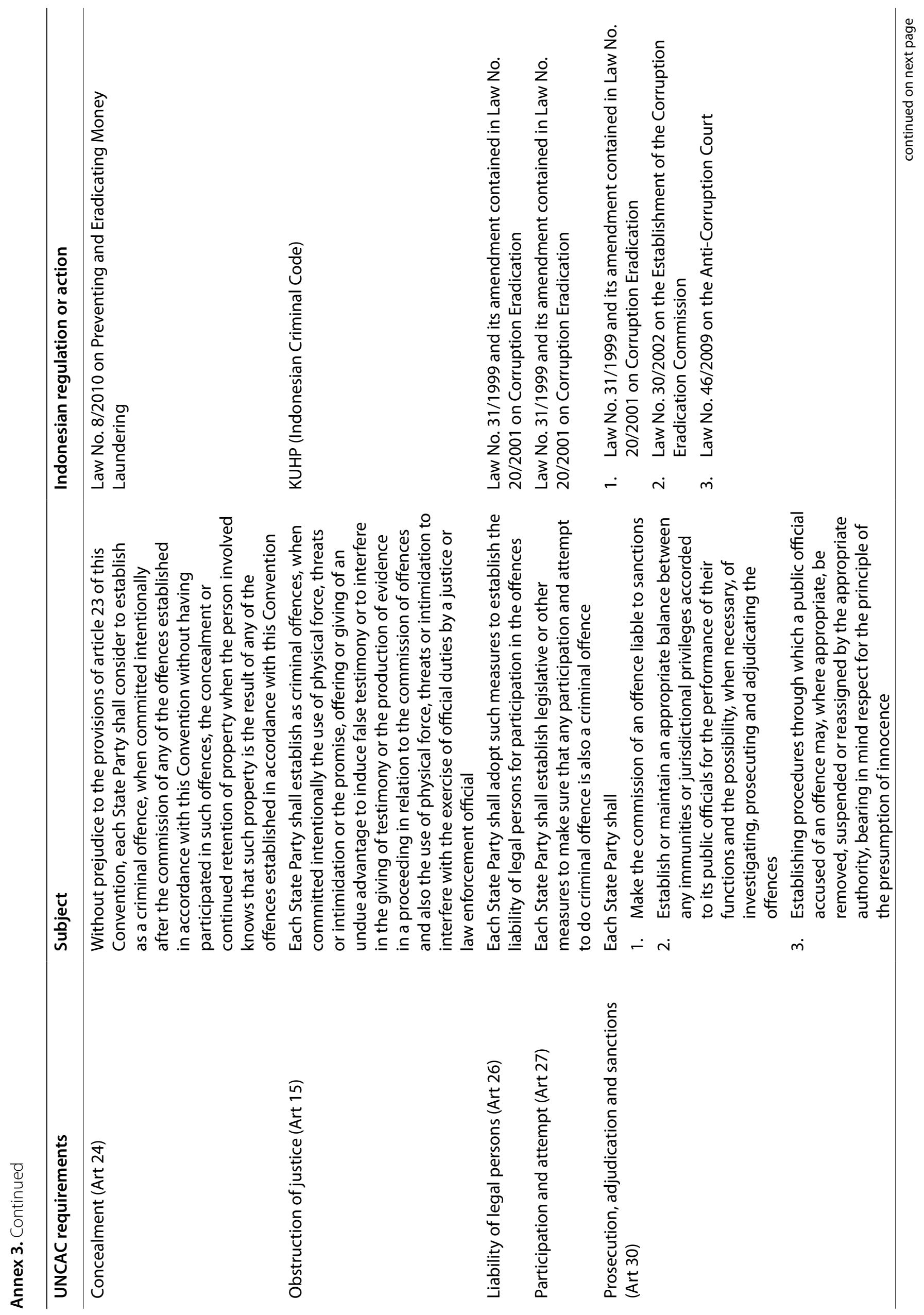




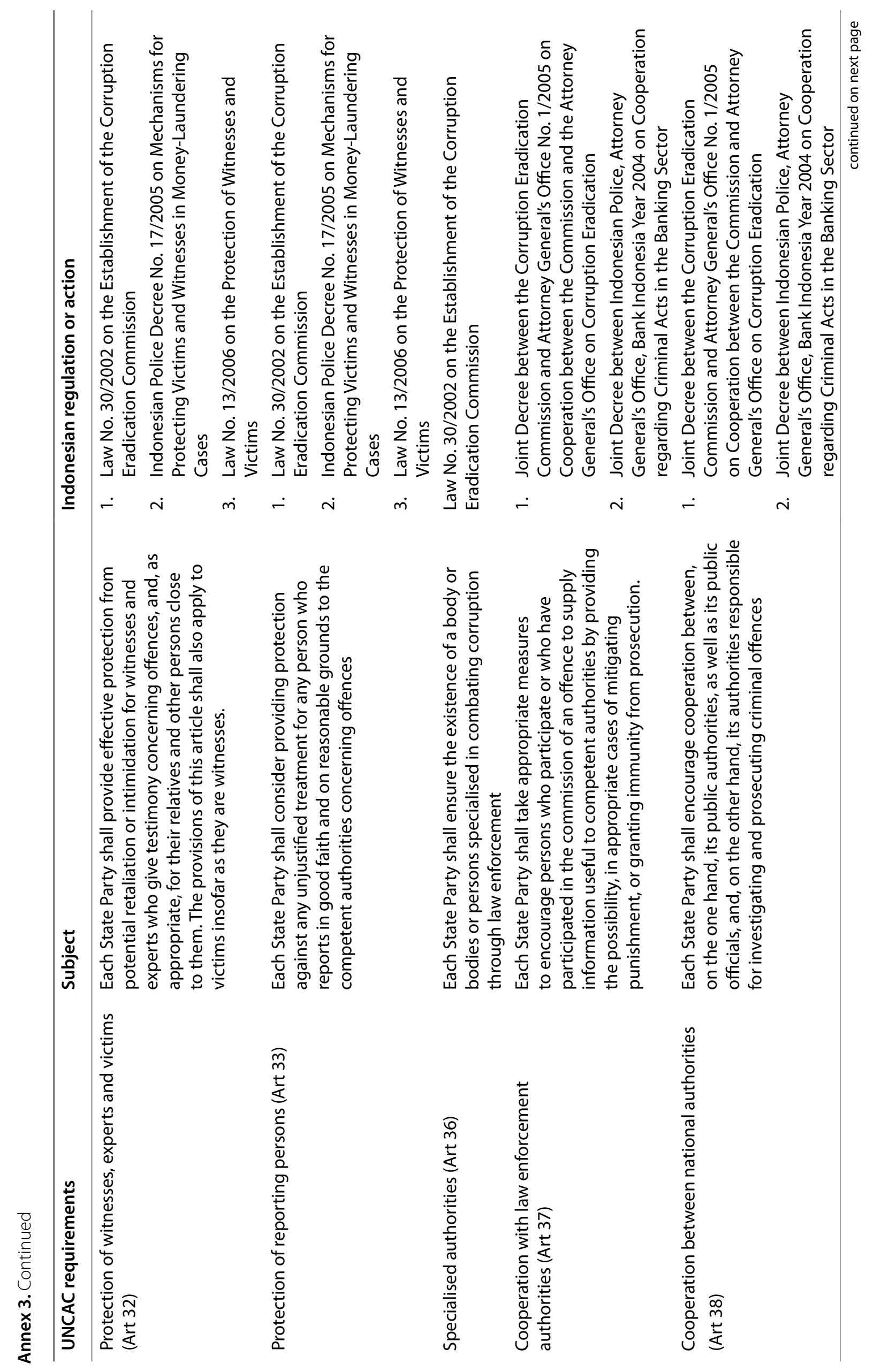




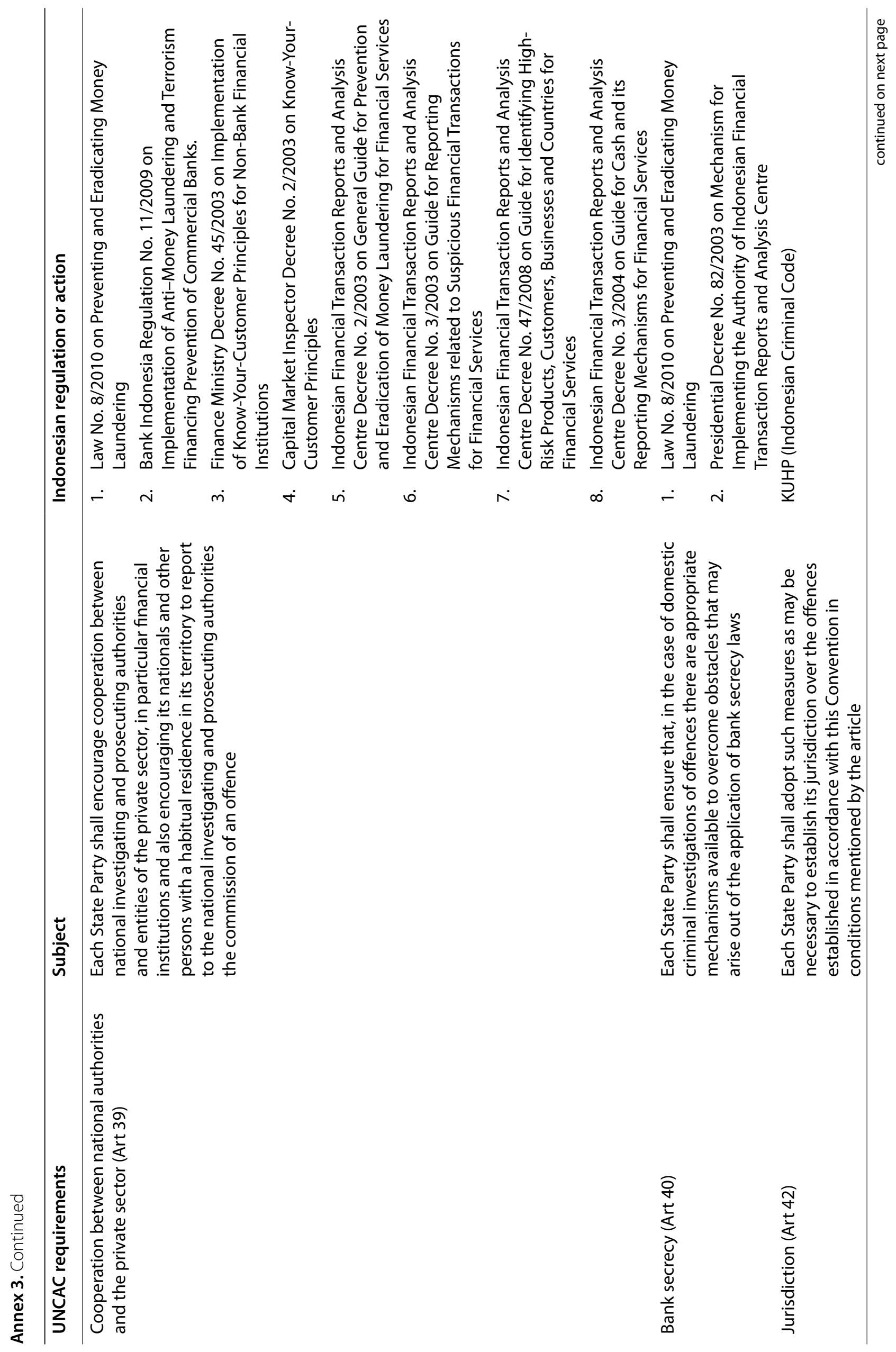




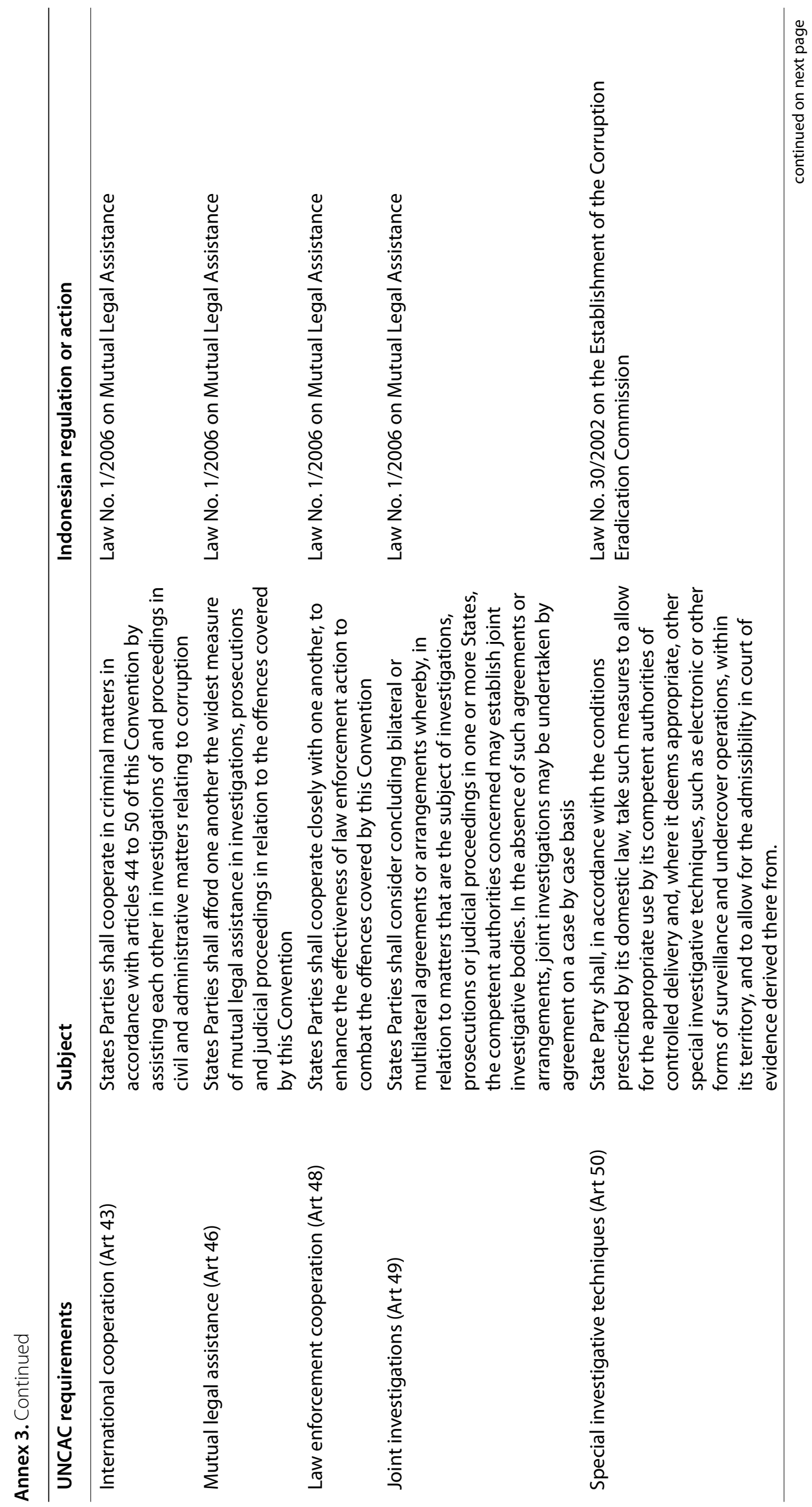




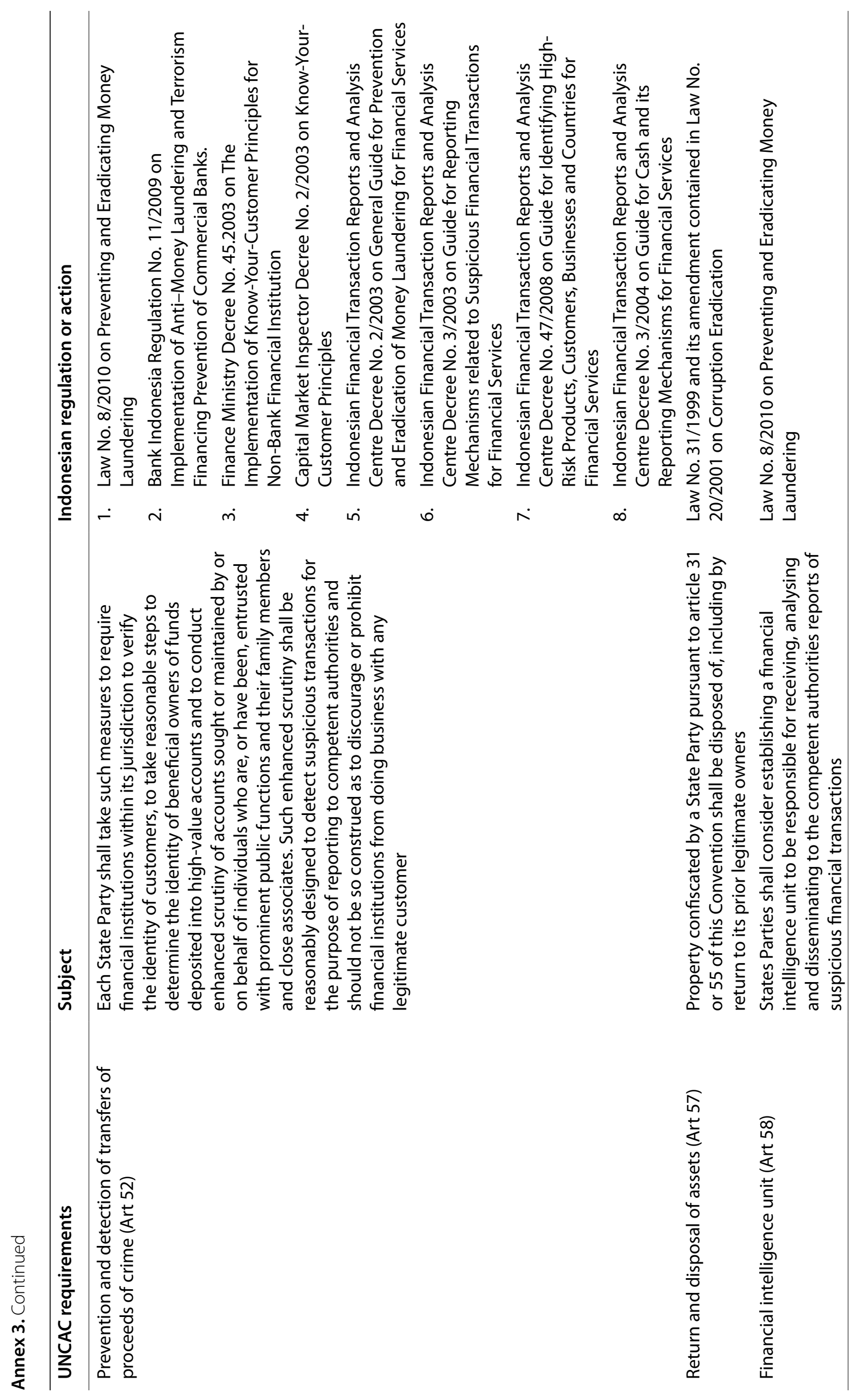




\section{Annex 4. PPATK minimum standards for banks}

The PPATK provides minimum standards for banks to determine the level of risk for each customer:

- probability that the customer misused products for money laundering or terrorist financing;

- probability that the customer conducted money laundering or terrorist financing;

- probability that the customer's business was used as a medium for money laundering or terrorist financing, or

- level of money laundering in the country where the customer resides.

Risks can be categorised by analysing the information given by customers regarding:

- identity (e.g. occupation, job position, status)

- business location

- the sum of transaction

- type of business

- company structure and beneficial ownership structure

- other relevant information available.

The risk-based approach must also be implemented for existing customers, including those who are in a forestry business. Banks must conduct customer due diligence (CDD) using the risk-based approach for existing customers when:
a. there is a significant increase in the value of transactions
b. there is significant disparity in the customer's profile
c. there is insufficient or incomplete information in the customer identification file
d. the account is anonymous or uses an alias

Source: Based on Bank Indonesia Regulation No. 11/2009 


\section{Annex 5. List of participants in the consultation meetings}

\section{Consultation meeting on risks of corruption in REDD+ in Indonesia, 28 March 2011, CIFOR, Bogor}

\begin{tabular}{|c|c|c|}
\hline No & Institution & Name/position \\
\hline \multirow[t]{2}{*}{1} & Bank Indonesia & Isti'ana Maftuchah \\
\hline & & Research and Bank Regulation \\
\hline \multirow[t]{2}{*}{2} & Bank Indonesia & Cicilia A. Harun \\
\hline & & Research and Bank Regulation \\
\hline \multirow[t]{2}{*}{3} & Bappenas & Basah Hernowo \\
\hline & & Director of Forestry and Water Resources Conservation \\
\hline \multirow[t]{2}{*}{4} & Bappenas & Nita Kartika \\
\hline & & Employee, Forestry and Water Resources Conservation Directorate \\
\hline \multirow[t]{2}{*}{5} & BPK (Supreme Audit Board) & Edward G. Hasiholan S. SE, MSc \\
\hline & & Head of Auditor IV A \\
\hline \multirow[t]{2}{*}{6} & BPK (Supreme Audit Board) & Sunarsana \\
\hline & & Employee, Auditor Utama IV \\
\hline \multirow[t]{2}{*}{7} & MFP UK & Andy Roby \\
\hline & & Co-Director and FLEGT VPA Facilitator \\
\hline \multirow[t]{2}{*}{8} & Ministry of Finance & Purwoko \\
\hline & & Researcher, Fiscal Policy Office \\
\hline \multirow[t]{2}{*}{9} & Ministry of Forestry & Listya Kusumawardhani \\
\hline & & $\begin{array}{l}\text { Director of Forestry Fees and Forest Product Distribution (BIKPHH), } \\
\text { Directorate General of Forestry Production Development (BUK) }\end{array}$ \\
\hline \multirow[t]{2}{*}{10} & Ministry of Forestry & Deden Djaenudin \\
\hline & & Researcher, Forestry Research and Development Agency (FORDA) \\
\hline \multirow[t]{2}{*}{11} & Ministry of Forestry & Sulistyo AS \\
\hline & & Researcher, Forestry Research and Development Agency (FORDA) \\
\hline 12 & $\begin{array}{l}\text { PPATK (Indonesian Financial Transaction } \\
\text { Reports and Analysis Center; INTRAC) }\end{array}$ & Agus Mulyana \\
\hline 13 & $\begin{array}{l}\text { PPATK (Indonesian Financial Transaction } \\
\text { Reports and Analysis Center; INTRAC) }\end{array}$ & Satra \\
\hline 14 & $\begin{array}{l}\text { PPATK (Indonesian Financial Transaction } \\
\text { Reports and Analysis Center; INTRAC) }\end{array}$ & Kario Silalahi \\
\hline 15 & $\begin{array}{l}\text { PPATK (Indonesian Financial Transaction } \\
\text { Reports and Analysis Center; INTRAC) }\end{array}$ & Haryono BP \\
\hline 16 & $\begin{array}{l}\text { PPATK (Indonesian Financial Transaction } \\
\text { Reports and Analysis Center; INTRAC) }\end{array}$ & M. Ali Afthan \\
\hline 17 & RARE & Yayat Afianto \\
\hline \multirow[t]{2}{*}{18} & UKP4 & Heru Prasetyo \\
\hline & & Deputy I of the REDD+ Presidential Task Force \\
\hline 19 & United States Forest Service & Jamie Halperin \\
\hline \multirow[t]{2}{*}{20} & UNODC & Ajit Joy \\
\hline & & Country Manager \\
\hline \multirow[t]{2}{*}{21} & UNODC & Novriady Erman \\
\hline & & Consultant \\
\hline 22 & World Bank & Emile Jurgens \\
\hline
\end{tabular}




\section{Focus group discussion on national strategies on preventing corruption and reducing fraud risks in REDD+ transfers and payments, 22 December 2010, Hotel Salak, Bogor}

\begin{tabular}{|c|c|c|}
\hline No & Institution & Name/position \\
\hline 1 & REDD Task Force Aceh & Fadmi Ridwan \\
\hline \multirow[t]{2}{*}{2} & District Government of Kapuas Hulu & Alexander Rombonang \\
\hline & & Expert Staff \\
\hline \multirow[t]{2}{*}{3} & Ministry of Forestry & Harry Budhi \\
\hline & & $\begin{array}{l}\text { Directorate General of Forestry Production } \\
\text { Development (BUK) }\end{array}$ \\
\hline \multirow[t]{2}{*}{4} & FORDA & Deden Djaenudin \\
\hline & & Researcher \\
\hline 5 & UKP4 & Roy Rahendra \\
\hline 6 & UNODC & Novriady Erman \\
\hline 7 & UNODC & Stepi H \\
\hline 8 & FORDA & Kirsfianti Linda Ginoga \\
\hline 9 & $\begin{array}{l}\text { PPATK (Indonesian Financial Transaction Reports and Analysis } \\
\text { Center; INTRAC) }\end{array}$ & Agus M. \\
\hline 10 & $\begin{array}{l}\text { Directorate General of Forestry Production Development (BUK), } \\
\text { Ministry of Forestry }\end{array}$ & Usman \\
\hline 11 & Fiscal Policy Office, Ministry of Finance & Purwoko \\
\hline 12 & Fiscal Policy Office, Ministry of Finance & Hendro Ratnanto \\
\hline 13 & UNODC & Paku Utama \\
\hline 14 & Bappenas & Pungky Widiaryanto \\
\hline \multirow[t]{2}{*}{15} & KPK & Deni R. Purwana \\
\hline & & Research and Development \\
\hline
\end{tabular}



This paper analyses the risks for corruption in REDD+ readiness activities in Indonesia and the conditions that may influence potential outcomes. REDD+ is a mechanism designed under the United Nations Framework Convention on Climate Change to enhance the role of forests in curbing climate change, which include forest conservation and activities that increase carbon stocks.

The Government of Indonesia has been introducing policies and regulations, creating coordinating mechanisms and initiating demonstration projects to prepare for REDD+. The REDD+ readiness phase in Indonesia involves significant funding from public and private sources. This paper focuses on the readiness phase because this is the period during which policies, institutions, systems and processes are designed. These will influence the presence or absence of risks and conditions for corruption in subsequent phases. The research relied on analysis of relevant legislation, interviews with agency officials, literature reviews and media reports. As Indonesia stands at the forefront in REDD+ policy reform and institutional design, it is hoped the analysis will also inform other forest-rich tropical countries and the donor community. 